Universidad de Lima

Facultad de Derecho

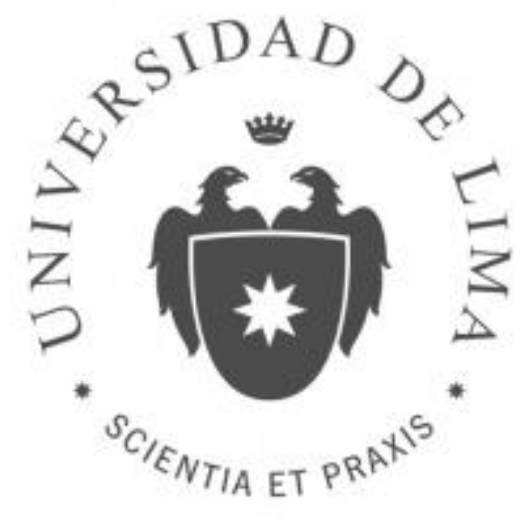

\title{
SOCIEDADES DE BENEFICIO E INTERÉS \\ COLECTIVO: UN APORTE SOCIETARIO AL BIENESTAR SOCIAL Y MEDIOAMBIENTAL
}

Tesis para optar el Título Profesional de Abogado

Juan Diego Mujica Filippi

Código 20100760

Asesor

Dr. Oswaldo Hundskopf Exebio

Lima - Perú

Octubre de 2016 


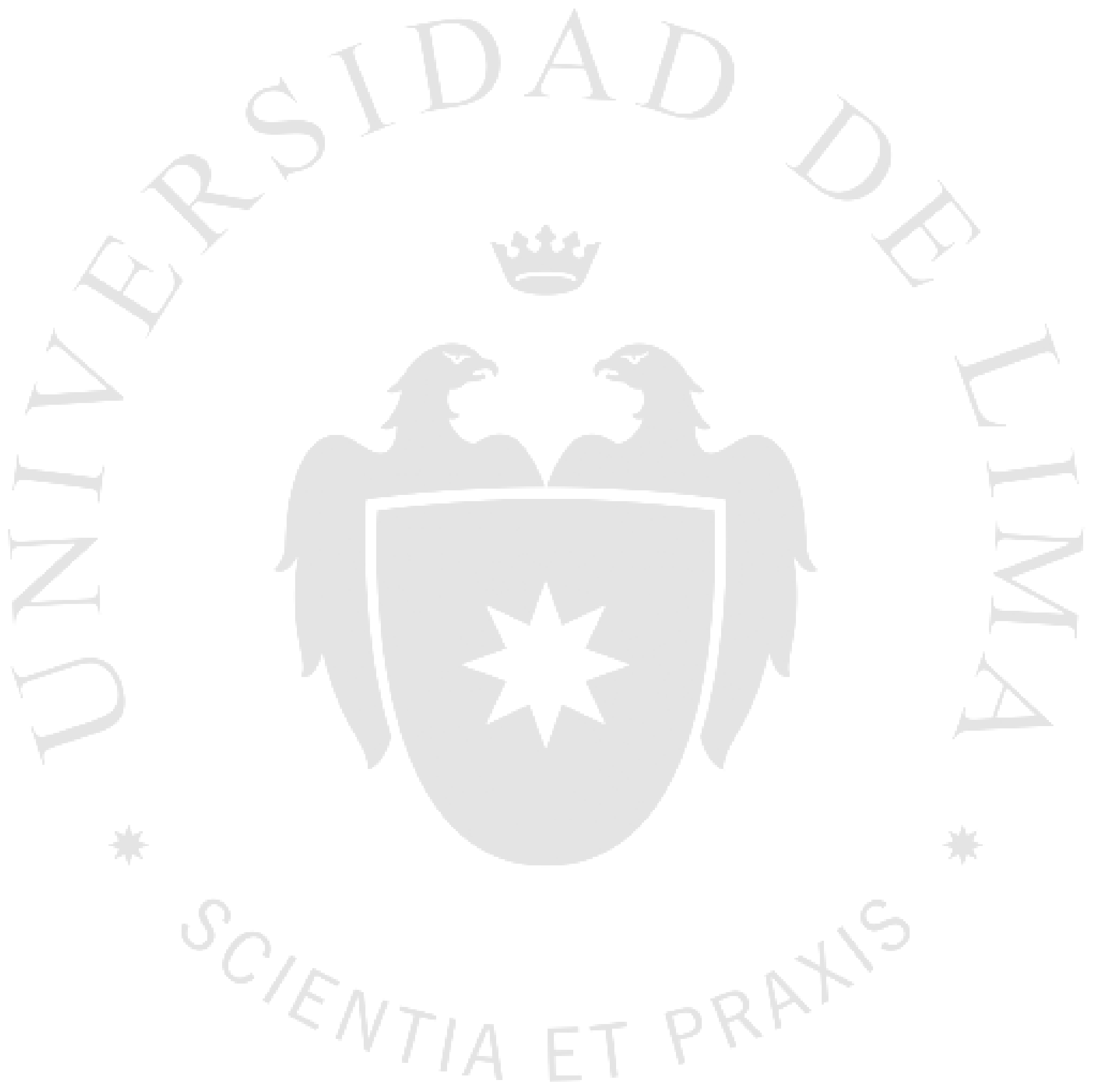


SOCIEDADES DE BENEFICIO E INTERÉS COLECTIVO: UN APORTE SOCIETARIO AL BIENESTAR SOCIAL Y MEDIOAMBIENTAL 


\section{TABLA DE CONTENIDO}

INTRODUCCIÓN

CAPÍTULO I: DELIMITACIÓN TEMÁTICA

1.1. Problemática $\quad 8$

1.1.1. Pregunta principal 10

$\begin{array}{ll}\text { 1.1.2. Preguntas secundarias } & 10\end{array}$

$\begin{array}{ll}\text { 1.2. Justificación de las razones de estudio } & 10\end{array}$

1.3. Motivación personal 11

1.4. Objetivos de la investigación 12

1.4.1. Objetivo general 13

1.4.2. Objetivos específicos 13

1.5. Hipótesis 14

1.6. Ámbito de la investigación $\quad 15$

$\begin{array}{ll}\text { 1.7. Estrategia metodológica } & 16\end{array}$

1.7.1. Tipo de investigación 16

1.7.2. Técnicas de recolección de datos 17

1.7.3. Análisis e interpretación de la información 17

CAPÍTULO II: SOCIEDADES DE BENEFICIO E INTERÉS COLECTIVO 19

$\begin{array}{ll}\text { 2.1. Sociedades híbridas } & 19\end{array}$

2.1.1. Cambio de paradigma 20

2.1.2. Evolución del propósito en las personas jurídicas 21

2.1.3. Ciudadanía corporativa con propósito 22

2.2. Sociedades de Beneficio e Interés Colectivo 25

2.2.1. Reseña histórica 26

2.2.2. Definiciones 28

2.2.2.1. Empresa B Certificada 28

2.2.2.2. Sociedad de Beneficio e Interés Colectivo 29

2.2.3. Elementos esenciales 30

2.2.3.1. Propósito de beneficio 31

2.2.3.2. Deberes y protecciones ampliados de los directores o administradores 36 
2.3. Organizaciones promotoras de las Sociedades BIC 43

2.3.1. B Lab 44

2.3.2. Sistema B Internacional 49

CAP'ITULO III: DESARROLLO LEGISLATIVO EN LAS AMÉRICAS

3.1. Estados Unidos de América $\quad 51$

3.1.1. Maryland $\quad 52$

3.1.2. California 57

3.1.3. Nueva York 59

3.1.4. Connecticut 1280

3.2. América Latina 62

3.2.1. Argentina 64

3.2.2. Chile $\quad 67$

3.2.3. Colombia 71

3.3. Cuadro Comparativo 75

CAPÍTULO IV: INSERCIÓN A LA LEGISLACIÓN NACIONAL

4.1. Situación actual $\quad 76$

4.2. Respuesta del Derecho Empresarial $\quad 80$

4.3. Regulación en el ordenamiento jurídico peruano $\quad 81$

4.3.1. Opciones legislativas en Latinoamérica 82

4.3.2. ¿Nuevo tipo societario? 84

$\begin{array}{ll}\text { 4.3.3. Categoría jurídica societaria } & 87\end{array}$

$\begin{array}{ll}\text { 4.4. Proyecto de ley } & 88\end{array}$

$\begin{array}{ll}\text { Conclusiones } & 104\end{array}$

$\begin{array}{ll}\text { Recomendaciones } & 106\end{array}$

$\begin{array}{ll}\text { Bibliografía } & 108\end{array}$ 


\section{ÍNDICE DE TABLAS}

Tabla 1. Comparación entre empresas.

Tabla 2. Diferenciación conceptual.

Tabla 3. B Impact Assessment

Tabla 4. Áreas programáticas evaluadas en 'B Impact Assessment'

Tabla 5. Desarrollo legislativo comparado 75

Tabla 6. Número de Empresas B en América Latina 77

Tabla 7. Empresas que han consultado la evaluación B en el Perú 


\section{INTRODUCCIÓN}

El mundo de hoy se encuentra afectado por serios problemas sociales y medioambientales que aquejan la vida de millones de personas alrededor del mundo. Con el advenimiento de las nuevas tecnologías, los ciudadanos tienen la posibilidad de enterarse de manera inmediata y gráfica de aquellos problemas que aquejan a sus prójimos y al planeta del cual forman parte. Es así que, ya nadie es totalmente ajeno de aquellos problemas sociales y/o medioambientales que suceden en nuestra comunidad, país o continente. El ser conscientes de realidades adversas nos impresiona como seres humanos; sin embargo, ello no es suficiente para hacer posibles cambios necesarios y tangibles en la realidad.

El presente trabajo de investigación analiza un fenómeno jurídico reciente, pero de rápida expansión: las sociedades de beneficio e interés colectivo. Las mismas constituyen un modelo de empresa que reconoce formar parte de una sociedad y medioambiente determinado, así como estar en una mejor posición para resolver de manera creativa y efectiva problemas concretos que afecten a la comunidad o al planeta Tierra. Todos aquellos involucrados en la gestión de las sociedades de beneficio e interés colectivo deben identificarse, paralelamente con los intereses económicos de la empresa, con un propósito de beneficio altruista que tenga algún impacto positivo en una realidad social o medioambiental determinada.

Con la finalidad de comprender el origen y naturaleza de las sociedades de beneficio e interés colectivo, se ha investigado el cambio de paradigma en el mundo de los negocios que ha forjado su naturaleza jurídica. Asimismo, se ha logrado identificar su origen conceptual y desarrollar con detenimiento los elementos esenciales que tipifican este modelo de sociedad. También ha sido objeto de investigación el desarrollo legislativo en las Américas, en donde el dinamismo comercial y el interés en optar por modelos sustentables y sostenibles de desarrollo económico han abierto paso a reconocer legalmente la existencia de empresas que realizan actividades económicas y también tienen propósitos altruistas.

Finalmente, la investigación desarrollada ha analizado la viabilidad de insertar las sociedades de beneficio e interés colectivo al ordenamiento jurídico nacional. Para ello, luego del análisis conceptual correspondiente, se ha elaborado un proyecto de ley que se caracteriza por hacer posible que las sociedades puedan insertar en su naturaleza societaria los elementos que le permitan ser una sociedad de beneficio e interés colectivo. 


\section{CAPÍTULO I: DELIMITACIÓN TEMÁTICA}

\subsection{Problemática}

En la actualidad, los conceptos y prácticas del desarrollo sostenible se han insertado en el rol y las actividades del sector público, el sector privado y el sector social. En 1987, la Comisión Mundial sobre Medio Ambiente y Desarrollo de la Organización de Naciones Unidas, definió, en su reporte "Nuestro Futuro Común" el concepto de desarrollo sostenible, siendo el mismo "aquel desarrollo que satisface las necesidades de las presentes generaciones sin comprometer la habilidad de las futuras para satisfacer sus propias necesidades" (Organización de Naciones Unidas, 1987).

Dicho reporte se erigió como una exhortación internacional a un cambio de raíces profundas a los tres sectores antes mencionados, con la finalidad que los mismos consideren el impacto social y medioambiental de sus operaciones. Es por ello que, hoy en día, el sector público, el sector privado y el sector social confluyen más que nunca antes. Hoy, dichos sectores se enfrentan a una redefinición de expectativas sociales en las cuáles el camino de la sustentabilidad social y medioambiental se erigen como una nueva alternativa para hacer negocios.

Es así que, el sector privado, en específico las personas jurídicas que desempeñan actividad económica, no son ajenas a la posibilidad de introducir en su organización interna políticas corporativas que conlleven de manera conjunta a los indicadores económicos, una perspectiva social y medioambiental que coadyuven a una mejor y mayor sustentabilidad en sus actividades.

Durante los últimos años del Siglo XX y la primera década del Siglo XXI, el empresariado ha sido testigo, de manera progresiva, a un cambio de paradigma en el cuál hay una revalorización del concepto de sustentabilidad y de la responsabilidad de los empresarios de contribuir desde su posición de privados con la solución de problemas locales, regionales o mundiales, así como con la preservación del medioambiente.

Aún al cambio de paradigma, las estructuras sociales, económicas y jurídicas de la sociedad peruana, no han recogido de manera integral las oportunidades de mejora corporativa, social y medioambiental que están presentes en otros países de la región y 
más aún del mundo. Con ello, la oportunidad del empresariado peruano de tener la posibilidad de implementar una categoría jurídica societaria que considere principios sustentables, así como propósitos sociales y medioambientales a la par de la actividad económica que realiza, se reducen a una mínima expresión. Asimismo, se desaprovecha un importante sector de negocio que puede generar ganancias económicas por el mismo hecho de apostar por principios sustentables en su estructura orgánica.

Ante este vacío, es imposible no tener en consideración la existencia de las denominadas Sociedades de Beneficio e Interés Colectivo (Sociedades BIC), también conocidas como "Empresas B", precisando que la "B" hace referencia a beneficios. Por ello, es importante preguntarnos ¿qué es una Sociedad BIC? "Es un modelo de empresa que amplía el deber fiduciario de los accionistas y gestores para incluir intereses no financieros, se compromete al impacto positivo en la sociedad y el medio ambiente y a operar con altos estándares de gestión y transparencia, al tiempo que busca el mejor rendimiento financiero y permite la repartición de utilidades entre accionistas" (Abramovay, 2013, p. 5). Esta nueva manera de negocios se está consolidando de manera progresiva y exitosa en países como Estados Unidos y Canadá, así como ha tenido avances importantes en América Latina durante los últimos años. No obstante, Perú es uno de los países donde este fenómeno aún se encuentra en una etapa incipiente.

El fenómeno de las Sociedades BIC es una respuesta directa al cambio de paradigma antes indicado, el cuál es además multidisciplinario, en tanto necesita de profesionales de distintas ramas que apliquen sus conocimientos y talentos en la inserción de principios sustentables en la actividad económica de las personas jurídicas. El abogado en general y en específico aquel especializado en Derecho Empresarial, no puede ser ajeno a este cambio de paradigma y debe prestar sus servicios legales con el objetivo de permitir el reconocimiento legal y la promoción de la Sociedades BIC como una opción atractiva de hacer negocios con un impacto social y medioambiental positivos, tan necesarios en el mundo de hoy.

Esta realidad hace propicia una investigación universitaria que acerque el concepto de las Sociedades BIC a la realidad nacional y en específico que permita dilucidar una respuesta jurídica integral a un fenómeno valioso, que contribuye con un impacto superior al lucrativo y que, sin dejarlo de lado, coadyuva con el bienestar social y medioambiental. 


\subsubsection{Pregunta principal}

De la problemática descrita en las líneas anteriores, y a partir de la misma, la pregunta principal de esta investigación es la siguiente:

¿Es posible incluir a la sociedad de beneficio e interés colectivo en la legislación societaria nacional? ¿Cuáles serían las implicancias legales de ello?

\subsubsection{Preguntas secundarias}

Asimismo, la presente investigación intentará responder a las siguientes preguntas secundarias, con la finalidad de ahondar en el tema y generar un conocimiento integral del mismo:

i. ¿Cuál es el origen de las sociedades de beneficio e interés colectivo? ¿Cuáles son las razones principales detrás de su naturaleza jurídica y económica?

ii. ¿Cuáles son los elementos esenciales de las sociedades de beneficio e interés colectivo? ¿Por qué hacen especial a este modelo de hacer negocios en comparación con modelos tradicionales?

iii. ¿Cómo se han desarrollado y evolucionado las sociedades de beneficio e interés colectivo en las Américas? ¿Cuáles son los países más representativos y con avances significativos en cuanto a legislación y negocios?

iv. ¿Estas sociedades constituyen un nuevo tipo societario? ¿Qué elementos debería considerar un modelo jurídico que regule la inserción de las sociedades de beneficio e interés colectivo en el Perú?

\subsection{Justificación de las razones de estudio}

¿Por qué realizar una investigación sobre el surgimiento de la sociedad de beneficio e interés colectivo y la implementación de un nuevo tipo societario en nuestra legislación? Este nuevo modelo de hacer negocios está en un proceso de institucionalización jurídica y práctica en el mundo de los negocios sin precedentes, formalizándose en diversas legislaciones y también influyendo en los planes de negocios de diferentes personas jurídicas aún en donde no existe reconocimiento jurídico alguno para estas sociedades. 
La importancia de las sociedades de beneficio e interés colectivo radica en la oportunidad de redefinir el éxito empresarial a través de la inclusión de principios sustentables que generen un impacto positivo para la sociedad y el medio ambiente. Asimismo, regula su propia figura orgánica con altos estándares de buen gobierno corporativo, promoviendo transparencia en sus decisiones y resultados, así como comprometiéndose con sus trabajadores, con el producto o servicio que ofrecen y con la comunidad y medio ambiente con el que interactúan o impactan.

Sin embargo, la introducción de esta figura en el mercado y operaciones económicas de nuestro país no podrá generar el impacto querido sin un correlato jurídico integral, que lo reconozca y norme adecuadamente. El Estado, si decide regular esta categoría en sus cuerpos normativos y procedimientos administrativos, permitiría la multiplicación, desarrollo y continuidad de este modelo de hacer negocios. En tal sentido, quien así lo decida podría tener una sociedad que, de manera paralela con el desarrollo de la actividad económica y la generación de lucro, presente resultados concretos según el propósito de beneficio social o medioambiental propuesto.

Por ello, al encontrarnos hoy en día en el momento de introducción y primeros pasos de este modelo de hacer negocios en el Perú, es necesario analizar los principios básicos en que se basan este modelo empresarial híbrido y ponderar la necesidad de brindarle o no la categoría de un nuevo tipo societario. Asimismo, la presente investigación tiene como finalidad última, la divulgación de la noción de qué es una Sociedad BIC o Empresa B y la generación de una atención académica general, partiendo del Derecho Empresarial, el cual tiene los elementos necesarios para introducir al ordenamiento jurídico nacional este nuevo esquema y responder adecuadamente a un cambio de paradigma que tiene mucho por contribuir y aportar.

\subsection{Motivación personal}

El presente trabajo de investigación responde a una profunda motivación personal por vincular en el ámbito del Derecho Empresarial a una diversidad de aspectos académicos, jurídicos y sociales que he tenido la oportunidad de estudiar al detalle durante los años de mi formación universitaria en la Universidad de Lima, así como durante los 
intercambios académicos que realicé en la Universidad Carlos IV de Praga en el año 2013 y en la Universidad de Ottawa en el año 2015.

Las sociedades de beneficio e interés colectivo son más que un nuevo modelo de hacer negocios ya que ellas permiten al emprendedor o empresario el poder dedicarse a la actividad económica con un propósito trascendental que responde a los objetivos del desarrollo sostenible promovidos mundialmente, muy especialmente por la Organización de Naciones Unidas. Este propósito, ya sea de naturaleza social o medioambiental, generará un impacto positivo en la vida de las personas a través de la respuesta a un problema social concreto o la protección del planeta Tierra y sus ecosistemas.

El Derecho Empresarial, ámbito del Derecho en el cual me he desarrollado profesionalmente hasta el momento, se vincula a través de la presente investigación, con temas de gran afinidad académica que he tenido oportunidad de estudiar a profundidad, como, por ejemplo, las personas jurídicas y su relación con los derechos humanos, así como la sostenibilidad social y medioambiental corporativa.

Es por ello que, es mi intención que esta investigación sirva de nexo multidisciplinario para que el sector privado en el Perú pueda ver reconocida la existencia de las empresas con propósito y de esa manera, el profesional capacitado sea un verdadero ciudadano corporativo. El ciudadano corporativo del Siglo XXI responde a un cambio de paradigma concreto, por el cuál a través de las tecnologías de la información, está permanentemente pendiente de los sucesos sociales y medioambientales que lo rodean. Por ello, él mismo quiere involucrarse de manera comprometida en su vida diaria con proyectos que lo empoderen y le permitan generar un impacto positivo que trascienda su esfera más próxima e individual.

En el año de investigación y redacción del presente trabajo de investigación, ha sido un motor muy especial el tener conciencia de la gran variedad de problemas sociales y medioambientales que pueden ser resueltos sin excluir el desarrollo rentable de la actividad empresarial. Personalmente, me identifico con el cambio de paradigma expuesto en el segundo capítulo del presente trabajo y quiero trabajar activamente por un mundo mejor.

\subsection{Objetivos de la investigación}

Con la finalidad de desarrollar la presente investigación, se ha delimitado un objetivo general y cinco objetivos específicos. Los mismos, se desprenden de la pregunta principal 
y las preguntas secundarias antes señaladas, con la finalidad de integrar el sentido de la investigación.

El objetivo general tiene como finalidad responder a la pregunta general de la investigación y se encuentra omnipresente durante todas las secciones de la misma. Constituye al mismo tiempo, un punto de partida, así como un punto de llegada, con la finalidad de contribuir con nuevos conocimientos sobre una realidad societaria novedosa que aporte al Derecho Empresarial.

Los objetivos específicos se desprenden a su vez de las preguntas específicas, en tanto tienen la finalidad de otorgarle sentido a la investigación a través de la selección de temas de importancia para la comprensión integral de los mismos. Estos temas se mencionarán a lo largo del trabajo, analizándolos críticamente para contribuir a una visión panorámica del tema de investigación.

\subsubsection{Objetivo general}

Determinar si es posible, dentro de los parámetros del ordenamiento jurídico peruano, la inclusión de la sociedad de beneficio e interés colectivo en la legislación societaria, promoviendo así el surgimiento de una persona jurídica híbrida, cuyo objeto social esté concatenado sinérgicamente con un propósito de beneficio social o medioambiental, lo que a su vez contribuya con el bienestar de la comunidad y el ambiente en el cual ésta realiza sus operaciones o impacta de alguna manera.

\subsubsection{Objetivos específicos}

La presente investigación considera su desarrollo temático en torno a los siguientes objetivos específicos:

i. Identificar el origen de las sociedades de beneficio e interés colectivo, así como las razones principales detrás de su conceptualización y la importancia jurídica y económica en la sociedad actual.

ii. Establecer cuáles son los elementos esenciales de las sociedades de beneficio e interés colectivo, con la finalidad de estudiar críticamente cada uno de ellos y comprender su diferenciación con los tipos societarios presentes en la legislación nacional. 
iii. Describir y analizar el fenómeno de las sociedades de beneficio e interés colectivo en países de las Américas, principalmente en estados representativos de los Estados Unidos de América y en países de América Latina que tengan avances significativos en cuanto a su implementación.

iv. Esbozar un modelo jurídico que contemple los elementos esenciales de las sociedades de beneficio e interés colectivo, así como promueva su reconocimiento en el Perú, introduciendo lo aprendido de experiencias extranjeras.

\subsection{Hipótesis}

Las sociedades de beneficio e interés colectivo constituyen una categoría jurídica societaria que debe ser incluida en la legislación peruana para efectos de promover en el sector empresarial la realización de un propósito de beneficio altruista, ya sea este social o medioambiental, adicional a la realización de la actividad económica. Las sociedades de beneficio e interés colectivo no suponen la incorporación de un nuevo tipo societario.

Esta categoría jurídica societaria debe ser incluida, en primer lugar, debido a que la naturaleza jurídica de las sociedades de beneficio e interés colectivo no difiere del concepto de sociedad y la consecución de una actividad económica, concepto consagrado en la legislación nacional. En segundo lugar, su inclusión resulta necesaria en tanto la sociedad de beneficio e interés colectivo se distingue ampliamente de los tipos societarios existentes por los principios de sustentabilidad presentes en ella, como lo son el propósito de beneficio social o medioambiental, la extensión de deberes de los directores o administradores de la sociedad, la importancia de la transparencia organizacional y el sometimiento a estándares evaluados por terceros. Finalmente, la legislación nacional se beneficiaría al recoger elementos propios de un cambio de paradigma en el mundo empresarial nacional e internacional, al propiciar un reconocimiento del Estado a una opción de hacer negocios generadora de éxitos compartidos, ya que la misma está diseñada para generar dividendos para los accionistas y a su vez, por convenio de estos, cambios positivos en un fin social o medioambiental específico.

Las implicancias de la inclusión de la sociedad de beneficio e interés colectivo en la legislación nacional serán positivas. Por un lado, brindarán al sector privado la 
posibilidad de elegir una categoría jurídica societaria adicional en la cual el objeto social guardaría una relación sinérgica indisoluble con un propósito de beneficio tangible, a su vez que permite el desarrollo de la actividad económica. Esta posibilidad, que responde al cambio de paradigma empresarial, permite conectar la venta de un producto o la provisión de un servicio con un interés público de interés para la sociedad, en tanto el impacto será positivo para una comunidad específica. Por otro lado, permitirá regularizar la situación de aquellas personas jurídicas, que vienen insertando en sus prácticas corporativas principios propios de las Empresas B, pero que se ven impedidas de operar bajo el sistema híbrido ${ }^{1}$, que está reconocido en las sociedades de beneficio e interés colectivo. En tal sentido, una vez disponible esta forma de asociación, dichas personas jurídicas podrán realizar los cambios jurídicos pertinentes en su forma societaria para poder perseguir con la misma relevancia, la generación de lucro y la consecución del propósito de beneficio querido.

\section{6. Ámbito de la investigación}

El ámbito de la presente investigación se centra en el Derecho Empresarial, en tanto las sociedades de beneficio e interés colectivo tienen una innegable naturaleza societaria que atender, analizar e interpretar.

Por ello, la sociedad en el Derecho Empresarial, la cual se erige como una organización de personas y recursos, tanto humanos como materiales, permite el desarrollo en común de actividades económicas dirigidas al mercado. El artículo primero de la Ley General de Sociedades indica que quienes constituyen una sociedad, lo hacen para el ejercicio en común de actividades económicas. La presencia del artículo primero es determinante y hace posible estudiar la inserción de las sociedades de beneficio e interés colectivo en el ordenamiento jurídico nacional en tanto nuestra legislación no se opone de por sí a la inclusión de principios altruistas y sustentables en las sociedades.

\footnotetext{
${ }^{1}$ En la presente investigación, el concepto de sistema híbrido hace referencia a aquellas empresas que tienen un alto valor social a raíz de la confluencia de principios propios del sector público, del sector privado y del sector social. Las Empresas B participan con regularidad en la economía y tienen una orientación social definida a través de su propósito de beneficio.
} 


\subsection{Estrategia metodológica}

Al tener una estrategia metodológica definida, la presente investigación ha podido hacer una cuidadosa selección del tema principal, así como de los temas secundarios que presentar, analizar e interpretar a lo largo de la misma.

En primer lugar, la estrategia metodológica utilizada permitió la definición del tipo de investigación a realizar, con la finalidad de delimitar adecuadamente la temática y la información obtenida. En segundo lugar, la misma permitió definir una estrategia de recolección de datos, ya que ante la vasta información pertinente al tema es importante conservar una línea investigativa clara. Finalmente, la estrategia metodológica empleada permitió el adecuado análisis e interpretación de la información utilizada, con la finalidad de desarrollar las conclusiones y recomendaciones que aporten a la comunidad en general y a la comunidad jurídica en especial.

\subsubsection{Tipo de investigación}

La investigación desarrollada en la presente tesis es bibliográfica y exploratoria. A continuación, se presenta una breve descripción de las características de estas dos maneras de investigar, con la finalidad de informarle al lector de cómo se ha desarrollado el presente trabajo académico.

Por un lado, la misma será bibliográfica en tanto se basa en fuentes normativas como doctrinarias, nacionales e internacionales, para analizar críticamente el problema de investigación y contrastar la hipótesis, teniendo en permanente consideración al objetivo general y los objetivos específicos antes descritos. Es por ello que, para la elaboración de la misma se ha revisado a diversos autores que han documentado satisfactoriamente el fenómeno a estudiar o han producido conocimientos de relevancia académica vinculados con el problema de investigación.

Por otro lado, la investigación será exploratoria ya que la misma se nutre de diversas fuentes y disciplinas que describen el surgimiento de las Empresas B en los Estados Unidos, así como su devenir jurídico en diversos países de las Américas. Asimismo, se recurre a fuentes que permiten discernir los elementos típicos de las sociedades de beneficio, lo que a su vez modela su conceptualización y naturaleza jurídica. En tal sentido, será posible discernir acerca de estos elementos, elaborar un 
proyecto de ley y preguntarse acerca de cuáles retos o problemas podrían enfrentar al insertarse en la legislación peruana.

El enfoque metodológico que define el tipo de investigación utilizado para la elaboración de la presente tesis pretende informar al lector de un tema nuevo para nuestra realidad, así como aumentar en el transcurso de la lectura de la presente investigación, su familiaridad con el tema principal y sus elementos típicos, los cuáles son consustanciales a la categoría jurídica societaria que se quiere analizar.

\subsubsection{Técnicas de recolección de datos}

Las técnicas de recolección de datos del presente trabajo provienen de fuentes bibliográficas. La recopilación de información es de gran importancia para el presente trabajo, en tanto, permite generar y divulgar el conocimiento existente sobre las sociedades de beneficio e interés colectivo, así como el análisis crítico sobre el mismo.

Los datos recolectados de las fuentes, están debidamente citados y señalados en la bibliografía. Los mismos provienen de fuentes de diversas disciplinas, en tanto el tema de investigación, si bien tiene una naturaleza inminentemente jurídica, se caracteriza también por ser auténticamente multidisciplinario, motivo de enriquecimiento permanente. Estos datos, a su vez, provienen de fuentes extranjeras y nacionales, en tanto el impacto en el Perú guarda correlación con el surgimiento y desarrollo de este tipo de sociedad en otros países de la región.

\subsubsection{Análisis e interpretación de la información}

La información y datos recolectados son analizados e interpretados críticamente, teniendo en consideración dos perspectivas fundamentales. Ellas son, la perspectiva integradora y la perspectiva jurídica, según se detalla en las líneas siguientes.

Por un lado, la información recolectada es trabajada desde una perspectiva integradora, con la finalidad de proveer de un amplio sentido al tema de investigación y aprovechar la gran variedad de disciplinas conexas, que hacen del mismo un tema verdaderamente multidisciplinario. Esta perspectiva, busca analizar e interpretar la información a través de un enfoque social y económico, el cuál pueda ser de aporte al empresariado para comprender la real dimensión de esta categoría jurídica societaria. 
Por otro lado, la información recolectada es trabajada desde una indudable y primordial óptica jurídica, en tanto es de suma importancia entender el tema de investigación como un punto importante en un cambio de paradigma en el mundo de los negocios que no puede ser ignorado por el Derecho. Es por ello que, los elementos esenciales de esta categoría jurídica societaria, deben analizarse a la luz de los conceptos e instituciones jurídicas existentes, así como de la legislación comercial pertinente que permitan responder a la pregunta principal.

A través de una interpretación jurídica del tema de investigación, se moldea un valioso aporte para el Derecho Comercial peruano, en tanto el mismo tendrá la oportunidad de estar nutrido de nuevos e importantes movimientos jurídicos en torno a la posibilidad de realizar actividad económica generadora de lucro y de bienestar social y medioambiental. 


\section{CAPÍTULO II: SOCIEDADES DE BENEFICIO E INTERÉS COLECTIVO}

\subsection{Sociedades híbridas}

La empresa tradicional pertenece al sector privado y desarrolla actividad económica, usualmente con la finalidad de repartir utilidades o dividendos entre sus accionistas. "No obstante, con la incorporación del concepto de desarrollo sostenible, y en respuesta a un contexto cada vez más demandante en términos sociales y ambientales, el sector privado evidencia un avance significativo hacia modelos de negocios en los cuales se incorpora las prácticas de la Responsabilidad Social Empresarial" (Abramovay, 2013, p. 14).

Las sociedades de beneficio e interés colectivo y su contribución al bienestar social y medioambiental irrumpen en el esquema tradicional de la actividad empresarial, en tanto la misma, como se explicará más adelante, realiza actividad económica y reparte utilidades a sus accionistas, pero a su vez está dedicada a la consecución de un propósito de beneficio el cual tiene la misma importancia en la organización que el objeto social.

Las Empresas B y las sociedades de beneficio e interés colectivo se encuentran en una categoría híbrida, en tanto las mismas convergen tanto características fundamentales de organizaciones de interés público, como las asociaciones y fundaciones, y de organizaciones de interés privado, como las figuras societarias tradicionales.

En tal sentido, los impulsores de las sociedades de beneficio e interés colectivo han denominado a estas sociedades como 'híbridas', siguiendo a las investigaciones de sociología económica de Andrew Hoffman y sus colaboradores. "Postular la hibridez de una organización empresarial supone un aparato teórico que va más allá de los instrumentos habituales de análisis de las empresas por parte de la abrumadora mayoría de la ciencia económica" (Abramovay, 2013, p. 16).

Se denominan sociedades híbridas, en esta área de estudio, a aquellas personas jurídicas que generan actividad económica, pero tienen un propósito social o medioambiental que se identifica con la misma existencia de la organización. "La hibridez de las empresas con propósito es una característica cada vez más importante para 
las grandes corporaciones privadas y sociales del mundo contemporáneo" (Abramovay, 2013, p. 17). Hoy en día, ya no es posible separar y dividir tajantemente a las organizaciones de interés público o social de las organizaciones de interés privado en tanto se da "la tendencia cada vez más clara de que las empresas privadas se relacionan e intentan incorporar las demandas sociales, no solo por lo que hacen los mercados, sino a través de la necesaria y permanente renovación de su licencia para operar" (Abramovay, 2013, p. 17).

La licencia para operar a la que hace referencia Abramovay, Correa y Van Hoof, puede traducirse en la licencia social que las personas jurídicas deben tener en el Siglo XXI para llevar a cabo sus operaciones en el marco del desarrollo sostenible, considerando a la sociedad local y global, así como al planeta Tierra. Las sociedades híbridas, reconocen la necesidad fundamental de desenvolverse en el mundo de los negocios poniendo en práctica estas nuevas premisas, cuyo impacto va más allá del desarrollo de la actividad económica y el reparto de dividendos.

\subsubsection{Cambio de paradigma}

Las sociedades híbridas responden a un cambio de paradigma en el mundo de los negocios, el mismo que inserta los principios de Desarrollo Sostenible en la actividad empresarial, y el cual tiene un correlato jurídico innegable al necesitar de la asistencia del Derecho para que reconozca y norme la aparición de esta nueva categoría jurídica societaria. Es innegable que el cambio de paradigma del cual ha surgido el concepto de las sociedades híbridas y, en específico de las sociedades de beneficio e interés colectivo, va contracorriente al estándar habitual de personas jurídicas que buscan la maximización de sus resultados en beneficio de sus accionistas sin considerar las implicancias sociales o medioambientales de sus operaciones.

Como se analiza en la presente investigación, las sociedades de beneficio e interés colectivo han tenido una rápida expansión en distintos estados de Estados Unidos de América y su discusión en América Latina es cada día más activa. No obstante, son las nuevas generaciones de empresarios y emprendedores aquellos que deciden optar por estos nuevos modelos de negocio. Como indica Baltazar Caravedo, "todo nuevo paradigma busca cambiar, erradicar o transformar el paradigma anterior. Pero ello no es un proceso simple que se termina tan pronto disponemos de un nuevo chip." (Caravedo, 
2015, p. 128). En tal sentido, las discusiones sobre la eficiencia de estos nuevos esquemas aplicados a las organizaciones empresariales son una pregunta recurrente a todos aquellos interesados en incluir una perspectiva social y medioambiental al núcleo de una idea de negocio.

Aún con cierta resistencia, el cambio de paradigma es tangible. Como mencionan Abramovay, Correa y Van Hoof, "en los últimos años, la separación tradicional entre empresas, organizaciones sin ánimo de lucro y servicios públicos se hace cada vez más difusa. En Sur América y en el resto del mundo se reconoce el surgimiento de empresas que buscan redefinir el sentido del éxito en los negocios: operan vendiendo bienes y servicios, pero lo hacen compitiendo por su capacidad de lograr un cambio social y ambiental positivo y no sólo por precio y calidad" (Abramovay, 2013, p. 13).

Las personas naturales que deciden crear empresas con propósito representan cada vez un mayor número. Muchas de estas, crean organizaciones bajo un régimen legal que no les permite desplegar el máximo potencial de sus operaciones, en tanto las mismas no solo se resumen a la venta de un bien o al proveer un servicio, sino que incluyen un propósito social o medioambiental que tiene como objetivo resolver un problema específico. El Derecho debe analizar y reconocer este cambio de paradigma, normando de manera adecuada la existencia de esta categoría societaria.

\subsubsection{Evolución del propósito en las personas jurídicas}

El propósito ha evolucionado en las personas jurídicas, en tanto ha ido irrumpiendo progresivamente en el modelo tradicional de las empresas a encontrarse hoy en día involucrado en el núcleo de las operaciones de las mismas. Este progreso no ha sido rápido ni fácil, por lo que "es interesante señalar que la evolución del concepto empresa moderna ha pasado de ofrecer un bien o servicio para hacer una máxima rentabilidad, a producir un bien o servicio haciendo ganancias, pero cuidando la sociedad y el medio ambiente, a resolver un problema social a partir del mercado generando rentabilidades mixtas (sociedad y empresa)" (Caravedo, 2015, p. 122).

El siguiente cuadro, elaborado por Sistema B Perú, señala una diferenciación conceptual en cuanto a la evolución del propósito en las empresas. 


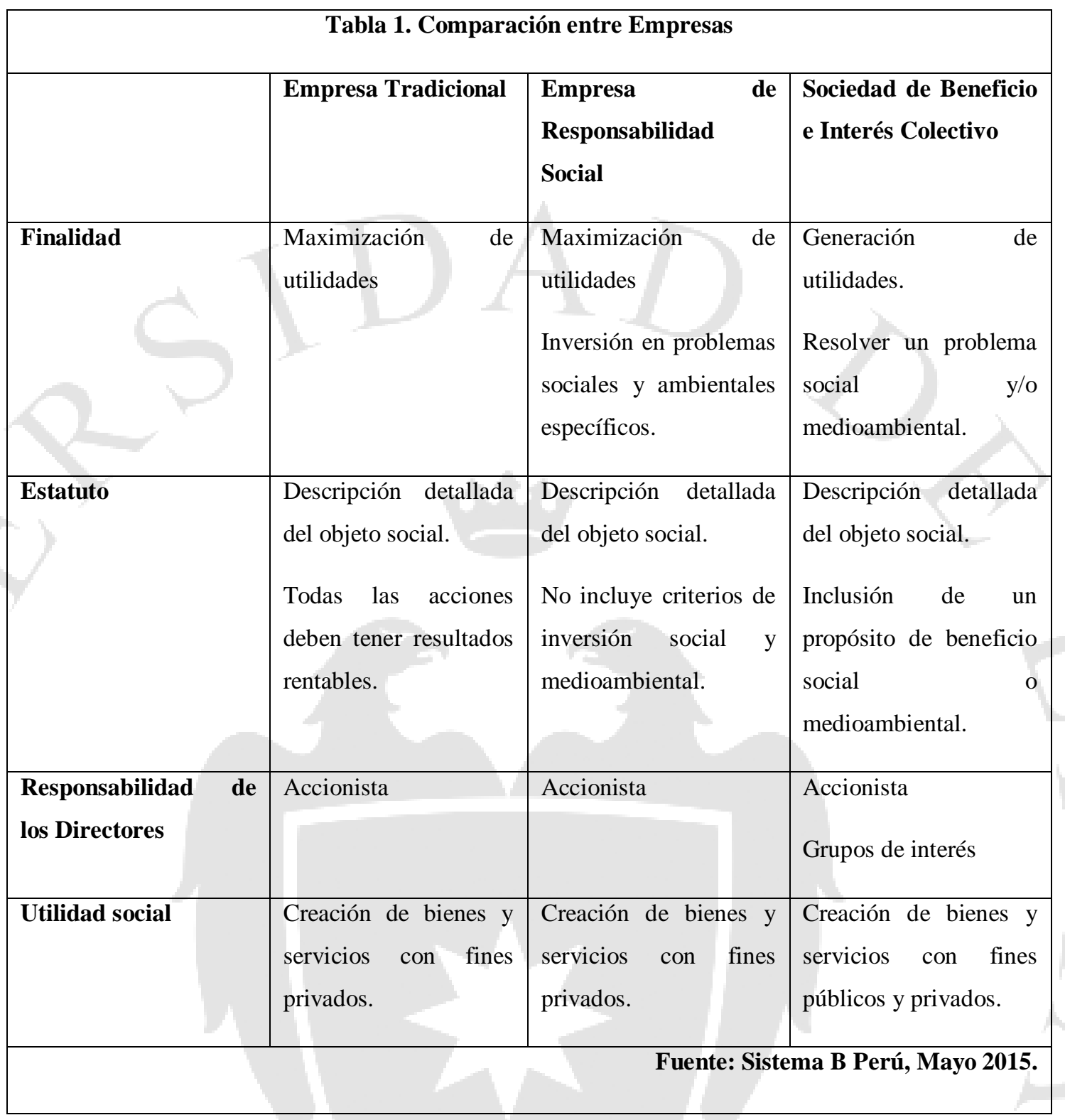

Las sociedades de beneficio e interés colectivo, categoría jurídica objeto de estudio en la presente investigación, es por excelencia la organización empresarial que presenta un propósito social o medioambiental claro y presente en toda la estructura organizativa de la persona jurídica.

\subsubsection{Ciudadanía corporativa con propósito}

Según el diccionario de la Real Academia Española, la palabra ciudadanía, significa en su tercera acepción, “comportamiento propio de un buen ciudadano". Hoy en día, el ser buen ciudadano se enmarca en la vida dinámica del Siglo XXI, en la cual gran parte de la población mundial trabaja en contacto con estructuras u organizaciones empresariales, las que tienen un rol tradicional en la sociedad de proveer bienes y brindar servicios, 
siendo un motor de la economía, generando empleo y cumpliendo con sus obligaciones tributarias para con el Estado.

La ciudadanía corporativa puede entenderse de dos maneras, las que se explican a continuación.

Por un lado, los ciudadanos, personas naturales, de hoy pueden llamarse 'ciudadanos corporativos' en tanto los mismos se encuentran insertos en el mundo laboral y dedican gran parte de su tiempo a las organizaciones corporativas a las que trabajan. Estas organizaciones exigen de ellos solvencia profesional, eficiencia y responsabilidad. Este ciudadano se inserta en una cultura de los negocios, inmersa en una sociedad dinámica que le exige buenas prácticas laborales, las cuales implicarán una mejora de condiciones laborales y personales.

Las personas naturales, ciudadanos corporativos del Siglo XXI, están inmersos en una cultura de inmediatez informativa, la cual permite que tomen conocimiento de situaciones fácticas del mundo que los rodea, muy en especial de los conflictos sociales y la degradación al medioambiente. En la era del Internet, motor fundamental del cambio social, y las redes sociales, herramientas que permiten informarse y compartir opiniones en el mundo virtual con consecuencias en la realidad social, los denominados 'ciudadanos corporativos' encuentran una disyuntiva en tanto sus índices de satisfacción laboral no se circunscriben a asuntos estrictamente personales, sino a aquellos que van en conexión con la búsqueda de un bienestar común.

Es así que, el trabajo empresarial o corporativo, ya no es el objetivo último de las nuevas generaciones. Estas buscan en sus labores diarias, un propósito que les permita trascender. La atención a los problemas sociales y medioambientales que aquejan al mundo de hoy y su combinación con el curso ordinario del trabajo empresarial se convierte así en el futuro de los ciudadanos, los que se erigen como ciudadanos corporativos con propósito. Los mismos, no buscan únicamente el lucro personal mediante su trabajo, sino el coadyuvar con la sostenibilidad social o medioambiental del mundo que los rodea.

Por otro lado, la ciudadanía corporativa también corresponde a las personas jurídicas, las cuales han tomado un rol en sociedad al ser miembros activos de la misma y gozar de gran poder e influencia. Los estudios Henri de Bettignies, académico del prestigioso instituto INSEAD, en Fontainebleau, Francia registran el devenir histórico, 
conceptual y académico de los diversos conceptos ligados a la reacción de las personas jurídicas ante el cambio de paradigma antes descrito. Desde el estudio independiente de la ética y filantropía, hasta la Responsabilidad Social Empresarial, hoy en día, se utiliza el término de 'ciudadanía corporativa' el cuál es más integral en tanto representa una nueva lógica corporativa de gran alcance, la misma que exige a las personas jurídicas tomar decisiones concretas a favor de la sustentabilidad, la igualdad de oportunidades y la valoración de la diversidad en todo ámbito de la organización.

Como indican Googins, Mirvis y Rochlin en su libro Beyond Good Company: Next Generation Corporate Citizenship (Más allá de una buena compañía: la nueva generación de ciudadanía corporativa), hay una clara diferencia en los estándares de conducta aplicados por las personas jurídicas en las últimas décadas del Siglo XX con el principio del Siglo XXI.

Si bien los conceptos de Responsabilidad Social Empresarial han estado presentes en el mundo de los negocios, "no hace mucho tiempo, el estándar de oro para la ciudadanía corporativa era ser una 'buena empresa'. Esto significaba tomar acciones serias para minimizar el daño causado por la actividad del negocio y maximizar los beneficios no solo para los accionistas sino también para un grupo amplio de grupos de interés. También significaba responder a las necesidades de la comunidad y responsables ante los grupos de interés por el comportamiento de la empresa” (Googins, 2007, p. 21).

Los cambios introducidos por la Responsabilidad Social Empresarial han sido beneficiosos en tanto han permitido hacer reflexionar al sector público y privado, así como a la sociedad civil, que la conducta de las personas jurídicas tiene un rol determinante en la sociedad y en el medio ambiente. Sin embargo, estos principios son insuficientes en la realidad de hoy.

Las personas jurídicas de hoy, y en especial del futuro, se caracterizarán por ser verdaderos ciudadanos corporativos. "La ciudadanía corporativa, que está comenzando a emerger en distintas corporaciones, conecta las operaciones estratégicas de un negocio con un propósito determinado. En varias de las empresas de las nuevas generaciones, la intención de las empresas es no solo hacer negocios de manera responsable y sustentable, sino trabajar directamente con un problema social o medioambiental" (Googins, 2007, p. 21). 
Las personas jurídicas, como ciudadanos corporativos, buscan también hoy en día un propósito que va más allá de la estructura tradicional de las organizaciones de maximizar los resultados económicos. Por el contrario, hoy en día y en especial, en el futuro, la atención a los resultados sociales y medioambientales basados en la protección y consideración especial a los diversos grupos de interés que rodean a la persona jurídica, se erigen como criterios importantes para determinar la existencia de un propósito concreto que irradie a toda la organización y sus miembros con la finalidad de contribuir con el bienestar social y medioambiental.

\subsection{Sociedades de Beneficio e Interés Colectivo}

Las sociedades de beneficio e interés colectivo son una nueva categoría jurídica societaria que propone un modelo híbrido de negocio, por el cual, se realizan actividades económicas en cumplimiento del objeto social, que hagan posible el reparto de dividendos a sus accionistas, pero a su vez, se trabaja activamente para el cumplimiento de un propósito de beneficio, ya sea este social o medioambiental.

Este modelo de negocio responde a una necesidad concreta de darle un mayor sentido a las organizaciones societarias respondiendo a las necesidades del Siglo XXI , y a través de su poder e influencia, generar cambios concretos positivos que coadyuven al bienestar social o medioambiental.

Los orígenes conceptuales de las sociedades de beneficio e interés colectivo están íntimamente relacionados con el cambio de paradigma descrito en la sección anterior. No obstante, es importante mencionar que, el desarrollo de esta categoría jurídica surge a partir de experiencias personales que luego de vividas, llevaron a la reflexión de cómo poder mejorar el mundo de los negocios a través de la participación activa del empresariado, inversionistas y otros profesionales en promoción y defensa del bienestar social y medioambiental.

Más aún, como se señala en la reseña histórica a continuación, las sociedades de beneficio e interés colectivo tienen como origen conceptual el utilizar el gran potencial que tiene el mundo de los negocios para contribuir con el bienestar social y medioambiental. Por último, es importante resaltar que el origen conceptual de esta categoría societaria es multidisciplinario, en tanto proviene de la administración y 
negocios, pero siempre reconociendo la necesidad de un adecuado marco legal que la regule y promueva, rol fundamental que ha y está cumpliendo el Derecho Comercial de las diferentes legislaciones que se estudiarán más adelante en el presente trabajo de investigación.

\subsubsection{Reseña histórica}

Las sociedades de beneficio e interés colectivo responden a los factores de cambio de paradigma señalados en el presente capítulo; sin embargo, su conceptualización como categoría corporativa y jurídica se originó en un intento de hacer un emprendimiento empresarial con una orientación al bienestar social y medioambiental.

El concepto jurídico de sociedades de beneficio e interés colectivo y la idea detrás de las Empresas B proviene del sector privado y de la experiencia de tres emprendedores norteamericanos, los cuáles, luego de crear y dirigir una sociedad con gran éxito económico, social y medioambiental, se dieron cuenta que al contrario de lo que ellos promovían, es política general en el mundo de los negocios prescindir de factores que contribuyan con el bienestar humano y del planeta Tierra con la finalidad de maximizar las ganancias económicas. Estos emprendedores son Jay Coen, Bart Houlahan y Andrew Kassoy.

Los tres, eran socios y directores de una sociedad denominada AND 1, cuyo objeto social era la producción y comercialización de zapatillas deportivas para basquetbolistas. "AND 1 era un negocio socialmente responsable, inclusive antes de la existencia del término; sin embargo, AND 1 no se habría identificado con tal término hoy en día, en tanto sus zapatillas deportivas no eran orgánicas, localmente producidas, o fabricadas con materiales reciclados. Pero, la compañía tenía espacios recreativos para jugar básquet en sus instalaciones, clases de yoga para los trabajadores, excelentes políticas para sus trabajadores por descansos de maternidad y paternidad y cada año entregaba $5 \%$ de sus ganancias a fundaciones y caridades locales para promover una educación de calidad y el empoderamiento de la juventud. Asimismo, AND 1 trabajaba continuamente con sus fábricas en el extranjero con la finalidad de implementar un código de conducta para sus proveedores y asegurarse que los trabajadores de estos últimos, tuvieran un salario justo, seguridad y salud en el trabajo y un desarrollo profesional adecuado" (Honeyman, 2014, p. 10). 
Las características antes mencionadas hacían de AND 1, una empresa diferente, en tanto sus políticas internas y externas estaban alineadas a la venta de un buen producto, la generación de buenas condiciones para todos los trabajadores de la persona jurídica y el bienestar general de la comunidad que los rodeaba. Asimismo, "AND 1 era financieramente exitosa. Desde sus humildes inicios en 1993, sus modestas ganancias de US\$ 4 millones en 1995 a obtener US\$ 250 millones de ganancias en el año 2001. Ello significó que AND 1 se convirtió en menos de 10 años, la segunda marca de zapatillas para jugadores de básquet en Estados Unidos, detrás de Nike” (Honeyman, 2014, p. 10).

Lamentablemente, los emprendedores Coen, Houlahan y Kassoy, perdieron el control de AND 1 por distintos motivos financieros y de estrategia de mercado. Finalmente, en el año 2005, vendieron AND 1. "Los resultados de la venta de la corporación fueron muy difíciles de observar. Aun así buscaron elegir el mejor comprador para la empresa y sus empleados, les fue devastador ver que luego de la venta, los compromisos de la empresa para con sus trabajadores, proveedores, la comunidad local y el medio ambiente fueron desmantelados luego de unos meses" (Honeyman, 2014, p. 11). Es a raíz de esta gran decepción con el mundo corporativo de Wall Street y la agresiva compra de AND 1 y el subsiguiente cambio en las políticas empresariales, que Coen Houlahan y Kassoy decidieron emprender un nuevo camino, con la intención que el mismo tenga un impacto en la mayor cantidad posible de personas.

Después de una profunda investigación y numerosas conversaciones con emprendedores, inversionistas y académicos, Coen, Houlahan y Kassoy entendieron que "había la necesidad de acelerar el crecimiento y amplificar la llegada de un sector empresarial responsable social y medioambientalmente." (Honeyman, 2014, p. 12). En estas conversaciones, identificaron la necesidad de gestar un marco jurídico que permita la existencia de un modelo híbrido de sociedad, que permita la generación de una actividad económica que reparta dividendos a los accionistas, así como el tener un propósito de beneficio que diferencie y posicione a este tipo de personas jurídicas de las comunes o tradicionales en el mercado.

Es así que, “en el año 2006, Coen, Houlahan y Kassoy cofundaron B Lab, una persona jurídica sin fines de lucro, dedicada a promover el poder de los negocios para resolver problemas sociales y medioambientales" (Honeyman, 2014, p. 12). Es en B Lab, 
donde desarrollaron los conceptos que se definirán a continuación, de Empresa B Certificada y de Benefit Corporation o sociedad de beneficio e interés colectivo.

Ambos conceptos son una gran contribución al mundo de los negocios y han merecido gran atención en Estados Unidos de América, en tanto, en respuesta al cambio de paradigma antes mencionado, y utilizando su experiencia personal, así como la experiencia de otros emprendedores e inversionistas, crearon una organización que motiva y acompaña a diversas personas jurídicas a ser sociedades sustentables, con un propósito que va más allá de la actividad económica que realiza.

\subsubsection{Definiciones}

La academia e incipiente doctrina jurídica en Estados Unidos de América y América Latina ha visto la necesidad de esclarecer y distinguir el concepto de las denominadas "Empresas B" y el término jurídico de las mismas una vez estas ingresan a las legislaciones nacionales como "Benefit Corporations" o empresas de beneficio, en Estados Unidos, o sociedad de beneficio e interés colectivo (Sociedades BIC) en América Latina.

A continuación, se definirá el concepto de Empresa B Certificada y sociedad de beneficio e interés colectivo. Ello, obedece a la razón que "las personas usualmente utilizan estos términos de manera intercambiable, cuando; sin embargo, existe una gran distinción entre las Empresas B, las cuales están certificadas, y las sociedades de beneficio e interés colectivo" (U, 2013, p. . 41). Creemos que clarificar el concepto es necesario, en tanto, en el Perú la presencia de las Empresas B es reciente y será su desarrollo y promoción progresiva la que finalmente permita o no la existencia de la categoría jurídica de las sociedades de beneficio e interés colectivo.

\subsubsection{Empresa B Certificada}

La denominación "Empresa B" proviene de la obtención de una certificación corporativa otorgada por B Lab, persona jurídica sin fines de lucro, constituida en Estados Unidos de América. La certificación como "Empresa B" puede otorgarse a cualquier persona jurídica que tenga actividad económica y reparta utilidades a sus accionistas, sin importar el país de su constitución o su tipo societario, siempre que la misma alcance el puntaje mínimo de ochenta puntos según la evaluación realizada por B Lab. 
Ahora bien, la organización certificadora, B Lab, "ayudó a desarrollar el modelo legislativo de las sociedades de beneficio e interés colectivo, y trabaja con la comunidad de Empresas B Certificadas y otros actores para apoyar la introducción de esta legislación en los estados en donde esta legislación no exista" (U, 2013, p. 41). Es decir, las Empresas B y sociedades de beneficio e interés colectivo comparten principios rectores, sus elementos esenciales y fines teleológicos; sin embargo, las Empresas B son denominadas así al haber obtenido de manera satisfactoria una certificación internacional, cuyos criterios y etapas serán explicados más adelante en el presente capítulo.

En tal sentido, puede definirse como Empresas B Certificada a aquellas personas jurídicas que realizan actividad económica y reparten dividendos a sus accionistas, las cuales sin importar su nacionalidad o su tipo societario, aprueban satisfactoriamente el proceso de certificación independiente, llamado 'B Impact Assessment', evaluado por B Lab.

\subsubsection{Sociedad de Beneficio e Interés Colectivo}

Las sociedades de beneficio e interés colectivo, o como se les conoce en Estados Unidos, "Benefit Corporations", en español, empresas de beneficio, "son entidades legales autorizadas por el Estado y no requieren ser certificadas como Empresas B" (Abramovay, 2013 , p. 23). Esta es una categoría jurídica societaria establecida en la ley que permite a las personas jurídicas adoptar la forma de una sociedad de beneficio y con ello formalizar jurídicamente la existencia de un propósito de beneficio así como los demás elementos esenciales a ser analizados en el presente capítulo.

Para que las sociedades de beneficio e interés colectivo tengan existencia jurídica válida, las mismas deben ser introducidas en las legislaciones nacionales a través de los procesos legales correspondientes. Como se estudiará en el siguiente capítulo, la mayor concentración de esta legislación se da en Estados Unidos de América, mientras que en América Latina el proceso de introducir esta categoría jurídica societaria se encuentra en permanente trabajo, logrando estar presente en las agendas legislativas de distintos países de la región.

Es así que, las sociedades de beneficio e interés colectivo, pueden definirse como personas jurídicas presentes en una determinada legislación comercial que "tienen ánimo de lucro y pueden distribuir utilidades a sus accionistas, a diferencia de las fundaciones" 
(Abramovay, 2013, p. 23), y otras personas jurídicas sin fines de lucro. No obstante, las mismas se caracterizan muy especialmente porque "los accionistas y gestores de las Benefit Corporations deben buscar construir un beneficio público y generar utilidades" (Abramovay, 2013, p. 23). Como se aprecia, es la existencia legal de las sociedades de beneficio e interés colectivo y su institucionalidad orgánica la fundamental diferencia entre la misma y las Empresas B Certificada.

Es importante recalcar una vez más que las sociedades de beneficio e interés colectivo no necesitan certificarse como Empresas B; sin embargo, aún al tener la categoría jurídica societaria pueden hacerlo con la finalidad de medir sus estándares y prácticas internas. Es labor del legislador nacional definir si esta categoría jurídica conllevará un mayor monitoreo al cumplimiento de sus obligaciones y propósito de beneficio, siendo la Certificación B una valiosa herramienta para ello.

\begin{tabular}{|l|l|l|}
\hline \multicolumn{2}{|c|}{ Tabla 2. Diferenciación Conceptual } \\
\hline \multicolumn{1}{|c|}{ Empresa B Certificada } & \multicolumn{1}{c|}{$\begin{array}{l}\text { Sociedad de Beneficio e } \\
\text { Interés Colectivo }\end{array}$} \\
\hline Procedencia & Sector privado. & $\begin{array}{l}\text { Híbrida. Fines públicos y } \\
\text { privados }\end{array}$ \\
\hline Naturaleza & $\begin{array}{l}\text { Proceso de certificación por } \\
\text { cumplimiento de estándares. }\end{array}$ & $\begin{array}{l}\text { Categoría jurídica societaria } \\
\text { creada por una ley. }\end{array}$ \\
\hline Reconocimiento & $\begin{array}{l}\text { Acreditación por B Lab, } \\
\text { organización sin fines de lucro } \\
\text { que certifica prácticas } \\
\text { corporativas. }\end{array}$ & $\begin{array}{l}\text { Legal, en tanto se siguen los } \\
\text { procedimientos establecidos por } \\
\text { el Estado. }\end{array}$ \\
\hline
\end{tabular}

\subsubsection{Elementos esenciales}

Las sociedades de beneficio e interés colectivo, como categoría jurídica societaria, comparten elementos esenciales con el concepto de Empresa B Certificada descrito en la sección anterior. Estos requisitos responden a los fines teleológicos que tienen por objetivo diseñar una persona jurídica que, sin alejarse de sus objetivos de éxito y rentabilidad económica, preste especial atención al bienestar social y medioambiental en la toma de decisiones estratégicas para su adecuado funcionamiento. 
De la investigación realizada, es posible concluir que son tres los elementos esenciales que caracterizan a las sociedades de beneficio e interés colectivo en la mayoría de las legislaciones en las que esta categoría jurídica societaria se encuentra presente o en discusión. El estudio y análisis de estos elementos esenciales son importantes para entender la naturaleza societaria de este modelo de negocio y sus posteriores implicancias en los cuerpos normativos correspondientes.

Los tres elementos son: en primer lugar, el propósito de beneficio; en segundo lugar, los deberes y protecciones ampliados de los directores o administradores y finalmente la observación de la transparencia y la publicación de reportes según un estándar definido por un tercero. La comprensión individual de estos elementos es de gran importancia para poder entender integralmente el verdadero sentido de las sociedades de beneficio e interés colectivo, así como los cambios jurídicos que la aparición de esta categoría jurídica societaria trae consigo a las legislaciones comerciales que decidan adoptarla.

\subsubsection{Propósito de beneficio}

El propósito de beneficio es el elemento esencial por excelencia de las sociedades de beneficio e interés colectivo. El mismo puede considerarse coetáneo a la conceptualización de las Empresas B en Estados Unidos. A diferencia de las sociedades tradicionales, "las sociedades de beneficio están requeridas de tener el propósito de crear un 'beneficio público general' y están permitidas de identificar 'beneficios públicos específicos' en su finalidad" (Halbert, 2015, p. 42). El propósito de beneficio se encuentra indisolublemente unido a la naturaleza jurídica de este tipo de sociedades, en tanto la consecución del objeto social y la actividad económica de la sociedad, deben estar pensados de manera integradora con la creación, por un lado, de un beneficio público general, y por el otro, de un propósito de beneficio específico, concreto y medible.

Ello, “difiere de la sociedades tradicionales, las cuales se encuentran permitidas de adoptar un propósito de beneficio cuando la legislación lo permita, pero no tienen que tener un propósito por mandato de la ley” (Halbert, 2015, p. 42). En tal sentido, a diferencia de las sociedades tradicionales, en los cuáles el objeto social es el concepto jurídico de mayor importancia en la sociedad, el cuál define y delimita las actividades de la misma, en las sociedades de beneficio e interés colectivo, el denominado propósito de 
beneficio cobra una importancia equiparable a la del objeto social en tanto ambos tienen una relación sinérgica. La misma debe buscar permanentemente y en toda la extensión de la persona jurídica, la realización de la actividad económica que genere ganancias para los accionistas, así como la consecución del propósito de beneficio social o medioambiental.

Es decir, el propósito de beneficio cobra un rol de importancia tal, que el mismo debe ser identificado como parte del espíritu corporativo organizacional. Ello debe traducirse en todos los planes estratégicos de la persona jurídica, así como en la formación y capacitación de sus trabajadores.

La importancia de definir al propósito de beneficio e incorporarlo en la sociedad, otorgándole la importancia consecuente con la naturaleza jurídica societaria de las sociedades de beneficio e interés colectivo, radica en que "esta definición permite ampliar la posibilidad de desarrollar acciones no relacionadas estrictamente con el retorno sobre la inversión de los accionistas, a diferencia de las empresas tradicionales, y amplía la obligación de rendir cuentas respecto del propósito de beneficio público" (Abramovay, 2013, p. 23). En tal sentido, la sociedad podrá realizar las acciones organizativas necesarias así como destinar fondos y sus correlatos contables a la consecución del propósito de beneficio e interés colectivo, sin estar los directores o administradores perjudicando el interés social al estar destinando fondos sociales a fines distintos al objeto social y la actividad económica que el mismo regula.

Al contrario, el propósito de beneficio social o medioambiental incorpora al marco jurídico de los directores o administradores de la sociedad, el deber de rendir cuentas e información sobre las acciones u omisiones, decisiones y progresos que tengan relación con este propósito. Este deber se incorpora y equipara a los deberes de desempeñarse en su cargo con la diligencia de un buen y ordenado comerciante, por lo que deberá velar por los intereses de la sociedad en un sentido integral, considerando la existencia e importancia de tanto el objeto social como del propósito de beneficio.

\section{Listado de propósitos de beneficio específicos}

La legislación estándar de sociedades de beneficio e interés colectivo, la cual ha inspirado la legislación en Estados Unidos de América y en países de América Latina, como se detalla en el capítulo siguiente, ha creado una lista no exhaustiva de propósitos de beneficios específicos que contienen las actividades de beneficio público más 
comunes, así como una cláusula cajón de sastre, para todo tipo de finalidades sociales y medioambientales. A continuación, explicaremos cada uno de los elementos de esta lista, de común repetición en diversas legislaciones que han adoptado o están por adoptar a la sociedad de beneficio e interés colectivo como una nueva categoría societaria.

\section{- Proveer a individuos o comunidades de bajos recursos o en situación de} vulnerabilidad con productos o servicios para su beneficio: las sociedades de beneficio e interés colectivo pueden delimitar su propósito de beneficio e incidir en realizar acciones que beneficien directamente, a través de los productos o servicios que ofrecen, a individuos o comunidades cuya situación económica sea precaria o se encuentren en una situación de vulnerabilidad o riesgo. Por un lado, el término 'bajos recursos' incide en la situación económica de individuos o comunidades, así como situaciones conexas tales como su ubicación geográfica, su acceso a alimentos, vestimenta y vivienda, etc. Por otro lado, el término 'situación de vulnerabilidad' se refiere a grupos de personas que estén en grave riesgo o involucradas en adicciones, conductas delictivas, sean víctimas de discriminación, entre otras características que afecten gravemente a su proyecto de vida.

La adopción de este propósito de beneficio específico conlleva el deber de la sociedad de beneficio e interés colectivo de identificar al grupo de individuos o las comunidades con las que desea colaborar, así como aquellos problemas que los aquejan.

- Promover mayores oportunidades económicas para individuos o comunidades más allá de la creación de trabajo en el manejo ordinario del negocio: este propósito de beneficio específico implica la búsqueda y generación de mayores oportunidades económicas para un grupo de individuos o una comunidad específica que no esté relacionada a su contratación y trabajo ordinario en la sociedad de beneficio e interés colectivo. Es decir, se excluye de este elemento la simple contratación de individuos o una comunidad en específico para llevar a cabo las labores que se realizan en consecución del objeto social; sin embargo, no se excluye la contratación y capacitación permanente en habilidades que promuevan una superación profesional en los beneficiarios. 
En tal sentido, la sociedad deberá plantear como su propósito de beneficio específico una actividad que permite la promoción de las habilidades u oportunidades de superación de las que gozan determinados individuos o comunidades, los cuales deberán ser previamente identificados.

- Preservar el medio ambiente: la preservación del medio ambiente está íntimamente ligada a la conceptualización de las sociedades de beneficio e interés colectivo. Por ello, la diversidad de temas ambientales y sostenibles es muchas veces el propósito de beneficio elegido por diversas personas jurídicas. Si bien todas las sociedades de beneficio e interés colectivo deben tener principios generales de sustentabilidad en todas sus operaciones, la preservación del medio ambiente como un propósito de beneficio específico requiere la delimitación de un área específica que pueda ser medible de la manera más objetiva posible.

Para las sociedades de beneficio e interés colectivo con este propósito específico, la preservación del medio ambiente está generalmente muy relacionada a la consecución del objeto social de la persona jurídica, en tanto en la actualidad, las oportunidades de negocio diseñadas para producir bienes o brindar servicios que estén conexos con el desarrollo sostenible y el medio ambiente reditúan económicamente y a la par permiten cambios tangibles a áreas o ecosistemas que sufren de algún tipo de deterioro ambiental.

- Mejorar la salud humana: el principio de sustentabilidad, presente en las sociedades de beneficio e interés colectivo, implican la promoción del bienestar y la salud humana. Ahora bien, el propósito de beneficio de mejora de la salud humana implica esfuerzos objetivos y conscientes por parte de la persona jurídica a, además de su actividad económica, realizar esfuerzos tangibles por un aspecto de salud pública de un determinado grupo de individuos.

Al referirse al término 'salud', es importante recordar que este término incluye distintas actividades que contribuyen al bienestar de los seres humanos, como la salud mental, el adecuado manejo del estrés, una nutrición balanceada, la promoción del deporte y la guía para una vida integral personal y profesional 
balanceadas. Por tanto, las repercusiones de este propósito de beneficio social pueden traer consecuencias muy positivas para el grupo objeto del mismo.

- Promover las artes, ciencias y el avance del conocimiento: las sociedades de beneficio e interés colectivo pueden optar como propósito de beneficio social medidas concretas que permitan la promoción de la ciencia y la cultura. Esta opción hace posible el desarrollo de actividades que generen y propulsen el conocimiento humano en el mundo artístico o científico.

Así como en los demás propósitos de beneficio sugeridos en el presente listado, es importante la delimitación particular de qué se quiere promover, con la finalidad de poder identificar de manera concreta el área específica en la cual se quiere tener un impacto social de importancia, que conlleve la labor activa de una persona jurídica que realiza actividad económica en incentivar, conservar o promover una determinada área cultural o científica de importancia para la sociedad.

- Incrementar el movimiento de capitales a entidades con un propósito de beneficio público: la presencia de este elemento en la lista de propósitos de beneficio es muy interesante en tanto presta atención al hecho que una sociedad de beneficio e interés colectivo puede dedicarse activamente a la conexión de capitales e inversiones con otras entidades con propósitos de beneficio público.

Ello toma ventaja de la constante búsqueda por parte de inversionistas y administradores de capital de invertir en personas jurídicas con propósito. Las sociedades de beneficio e interés colectivo se erigen como este tipo de personas jurídicas por excelencia y su reciente protagonismo como una nueva figura corporativa ha generado el interés de inyectar capital en proyectos que generen actividad económica sustentable y con altos índices de rendimiento, pero al mismo tiempo consideren propósitos sociales o medioambientales específicos. 
- La consecución de cualquier otro beneficio social o medioambiental específico: esta cláusula es denominada cajón de sastre, en tanto en la misma es posible colocar a todos aquellos propósitos de beneficio, sean estos sociales o medioambientales, que cumplan con el requisito de especificidad.

Ello permite concluir que las sociedades de beneficio e interés colectivo son orgánicamente abiertas a tener un propósito de beneficio que coadyuve al bien social o medioambiental, sin que este esté necesariamente especificado en la lista diseñada y diseminada.

Si bien el listado y las descripciones mencionadas líneas arriba no es obligatorio ni mucho menos común a todas las legislaciones que han adoptado a las sociedades de beneficio e interés colectivo, el mismo es instructivo en cuanto permite hacerse una idea de la gran variedad de temas que pueden a su vez conectarse con situaciones específicas que permitan el diseño de un propósito de beneficio. Sin embargo, como se verá en el siguiente capítulo, el listado es un punto de partida

Jurídicamente, el propósito de beneficio debe estar redactado de manera detallada, es decir debe describir de manera concreta la finalidad social o medioambiental que se quiere lograr. Esta descripción debe ser consignada en el documento público inscrito, el cual rige los órganos, el funcionamiento y la administración de la sociedad. Es por ello que, el propósito de beneficio es vinculante entre los accionistas de la sociedad y serán los directores o administradores de la misma los responsables de, conjuntamente con el objeto social, realizar sus fines y ofrecer resultados en torno al mismo.

\subsubsection{Deberes y protecciones ampliados de los directores o administradores}

Los directores o administradores de las sociedades de beneficio e interés colectivo tienen mayores deberes y responsabilidades que los directores o administradores de las sociedades tradicionales. Asimismo, estos actores presentan mayores derechos en el ejercicio de sus funciones, con la finalidad de poder tomar decisiones que propicien la relación sinérgica entre el objeto social y el propósito de beneficio social o medioambiental. 


\section{Ampliación de deberes de directores o administradores}

Por un lado, la ampliación de sus deberes obedece a la aparición e incorporación del propósito de beneficio, en los términos descritos en la sección anterior. Por ello, los directores o administradores de la sociedad tienen, como deber correspondiente a su cargo, que velar por el manejo ordenado y ordinario de la actividad económica a partir del objeto social y trabajar constantemente por la consecución del propósito de beneficio social y medioambiental.

Asimismo, es común en las legislaciones que han incorporado a la sociedad de beneficio e interés colectivo a su ordenamiento jurídico, la ampliación expresa de los deberes fiduciarios de los directores o administradores. La ampliación de deberes fiduciarios consiste en que los directores deberán considerar en todo momento el mejor interés económico para la sociedad; sin embargo, tal no será el único criterio a considerar en su desempeño como líderes de una sociedad de beneficio e interés colectivo. Adicionalmente, los directores o administradores deberán ponderar los efectos que sus acciones u omisiones puedan tener en una serie de actores vinculados de manera estrecha y de manera potencial con la sociedad.

"Tanto los directores como los gestores de la empresa están obligados a considerar los efectos de las actividades de la empresa en una amplia gama de partes interesadas, como accionistas, empleados, clientes, la comunidad, el medio ambiente local y mundial y los intereses a corto y largo plazo de la empresa" (Abramovay, 2013, p. 23). En tal sentido, es importante tener en cuenta de la redefinición y ampliación de los deberes de los directores o administradores en las sociedades de beneficio e interés colectivo, en cuanto estos responden de manera integral por el funcionamiento económico de la sociedad como por el cumplimiento del propósito de beneficio.

Ahora bien, como lo indican Abramovay, Correa y Van Hoof, el cumplimiento del propósito de beneficio no se considera de manera aislada, en tanto la ampliación de deberes antes mencionada, incluye también a una gama de actores que tiene relación mediata e inmediata con la sociedad.

En primer lugar, se hace referencia a los accionistas, los mismos que en el pacto social han regulado sus voluntades con la finalidad de optar por una categoría jurídica en donde la sociedad debe actuar integral y comprensivamente para lograr sus objetivos económicos de acuerdo al objeto social y sus objetivos sociales o medioambientales de 
acuerdo al propósito de beneficio. No obstante, los directores y administradores tienen el deber asegurar la estabilidad económica de la sociedad y el retorno de utilidades a los accionistas.

En segundo lugar, el concepto de sociedades de beneficio e interés colectivo considera prioritario el bienestar integral de los trabajadores de la persona jurídica. En tal sentido, los directores y administradores de la misma adquieren una responsabilidad por la correcta gestión de las relaciones labores al interior de la sociedad, así como por la promoción de las mejores prácticas en cuanto a la contratación de personal como del clima de trabajo. La sociedad de beneficio e interés colectivo, al originarse de las Empresas B, llevan consigo los principios que motivan a dichas sociedades a certificarse, los cuáles serán comentados en el presente capítulo. Por ello, se espera que el estándar utilizado para las relaciones con los trabajadores sea mayor y el mismo se nutra de las mejores prácticas de buen gobierno corporativo para asegurar la capacitación permanente del personal y crear un vínculo tanto con la realización de las actividades destinadas al cumplimiento del objeto social como con la consecución al propósito de beneficio. Se espera que los directores o administradores entiendan esta primordial diferencia entre las sociedades de beneficio e interés colectivo y las sociedades tradicionales, y ello a su vez, se vea reflejado en las decisiones que los mismos tomen en su manejo del negocio.

En tercer lugar, los directores o administradores deberán tener en muy especial consideración a los clientes, quienes son el sustento del negocio y de su propósito de beneficio. La importancia del cliente y su satisfacción como parte del esquema de la persona jurídica y por ende sujeto a ser impactado por las decisiones que la misma pueda tomar por sus representantes, hace que los directores o administradores deban considerarlos a ellos como sujetos involucrados en su toma de decisiones.

En cuarto lugar, la sociedad de beneficio e interés colectivo debe considerar, en todo momento, que es un miembro más de la comunidad en la cual se ubican sus operaciones. En tal sentido, las personas y ecosistemas que rodean aquellos lugares donde desempeñan sus actividades, ya sean estas provenientes del objeto social o del propósito de beneficio, deben ser tomados en cuenta en todas las decisiones que sus directores o administradores tomen. El objetivo de ello es asegurar una relación de cordialidad e integración, donde la persona jurídica no se vea de manera antagónica a los intereses comunitarios de aquellas personas que la rodean, sino como un actor más de la sociedad 
civil, que pueda aportar al adecuado manejo de las relaciones vecinales o de la conservación o mejora de la sociedad y medio ambiente que la rodean.

En quinto lugar, el medio ambiente local y mundial son aspectos consustanciales al concepto de sociedad de beneficio e interés colectivo, en tanto los directores y administradores de la misma tienen el deber de actuar en consecuencia al propósito público general de proteger el medio ambiente. Esta protección debe traducirse en acciones tangibles omnicomprensivas con una clara visión de protección de los ecosistemas que rodean a la sede física de la sociedad, así como prácticas institucionales que coadyuven a la preservación general del medio ambiente. A través de la permanente consideración del medio ambiente en las decisiones que debe tomar la persona jurídica a través de sus representantes, se quiere asegurar el compromiso de la misma con el desarrollo sostenible y la necesidad de tomar acciones concretas con la finalidad de reducir la contaminación y sus efectos negativos en el medio ambiente.

Finalmente, los directores o administradores de las sociedades de beneficio e interés colectivo deben tener en permanente consideración a la hora de tomar sus decisiones a los intereses a corto y a largo plazo de la persona jurídica. Estos intereses no deben ser analizados de manera aislada, en tanto los mismos deben de considerar la relación sinérgica entre la consecución del objeto social y del propósito de beneficio. Por ello, la toma de decisiones debe considerar el costo económico de las operaciones que permitan la generación de ganancias económicas, así como las posibilidades de continuar con el desarrollo del propósito de la persona jurídica para su mayor y mejor cumplimiento.

Es posible concluir que este elemento esencial de las sociedades de beneficio e interés colectivo incorpora una tarea más grande y compleja para los directores o administradores, en tanto los mismos deberán tener en permanente consideración a una serie de grupos de interés que no necesariamente pueden tener relación directa e inmediata con la persona jurídica. En tal sentido, esta ampliación de deberes, si bien hace posible que los directores o administradores puedan trabajar en todo el sentido teleológico que llevan consigo esta categoría societaria, también implica una responsabilidad de grandes implicancias, ya que los mismos deberán hacer una valoración de una multiplicidad de factores, que en muchas oportunidades se opondrán entre sí. 


\section{Ampliación de protección para los directores o administradores}

Por otro lado, la legislación estándar y los estatutos de las sociedades de beneficio e interés colectivo presentan mayores protecciones para los directores o administradores de las mismas. Estas protecciones obedecen a la ampliación de deberes mencionados líneas arriba. En tal sentido, "la consideración de todos los grupos de interés no constituye una violación a los deberes estándar de los directores, los que requieren de buena fe, el manejo del negocio como un buen y ordenado comerciante, y la consideración de los mejores intereses económicos de la sociedad" (Halbert, 2015, p. 43).

Por ello, los directores o administradores podrán tomar las decisiones necesarias para considerar a los grupos de interés y cumplir con las metas trazadas por el propósito de beneficio. Esta protección es importante, en tanto los accionistas no podrán demandar judicialmente por responsabilidad a sus directores o administradores por tomar decisiones responsables pero que no tengan como única finalidad la maximización del lucro. Esta protección permite un margen de acción importante para los directores o administradores de la sociedad, en tanto los mismos podrán tomar las decisiones necesarias para la consecución de los objetivos económicos, así como la consecución del propósito de beneficio, considerando a los grupos de interés antes descritos.

Asimismo, como parte de la esfera especial de protección a los directores o administradores de la sociedades de beneficio e interés colectivo, "los directores también están protegidos de demandas por parte de los beneficiarios del propósito de beneficio de la sociedad" (Halbert, 2015, p. 43). Es así que, la legislación mayoritaria en Estados Unidos de América y otros países de la región toman especial atención en señalar que no proceden demandas judiciales por responsabilidad por su cargo contra los directores o administradores por parte de los beneficiarios del propósito de beneficio de la sociedad. Ello responde a la implementación progresiva del propósito de beneficio según un programa elaborado con etapas y estándares, lo cual no va necesariamente acorde con las expectativas de satisfacción de necesidades inmediatas de ciertos grupos sociales que pueden ser beneficiarios de dichos propósitos. Esta protección obedece, tal como lo indica Halbert, a no desincentivar a personas de asumir roles de liderazgo como directores o administradores en las sociedades de beneficio e interés colectivo.

Si bien los directores y administradores de la sociedad tienen una ampliación en su protección legal, los mismos pueden ser sujeto de demandas judiciales comunes por 
parte de los accionistas de la sociedad. Estas demandas pueden darse por "no considerar adecuadamente los intereses económicos de los accionistas" (Halbert, 2015, p. 43) y en específico, en las sociedades de beneficio e interés colectivo por "no considerar los intereses de los grupos de interés (por ejemplo, cuando los directores no consideren adecuadamente el impacto de una acción particular en la fuerza de trabajo de la compañía)" (Halbert, 2015, p. 43). Por ello, los directores o administradores de las sociedades de beneficio e interés colectivo deberán incorporar estos nuevos criterios en su proceso de toma de decisiones.

Los deberes y protecciones de los directores o administradores de las sociedades de beneficio e interés colectivo son, sin duda, un elemento esencial de esta categoría societaria, la cual difiere orgánicamente de las denominadas sociedades tradicionales. La finalidad de asignar mayores deberes y a su vez mayores protecciones está diseñada para empoderar a quienes asuma tales roles a considerar el propósito de beneficio y a los grupos de interés como nuevos e importantes elementos que tomar en cuenta a la hora de tomar decisiones corporativas y también para asegurarse de cumplir con los objetivos generales sociales y medioambientales propios de este nuevo paradigma.

\subsubsection{Transparencia de información Informe Anual de Beneficio}

Si bien la transparencia es un principio de buen gobierno corporativo, la misma cobra un nuevo significado en las sociedades de beneficio e interés colectivo. Los estándares de transparencia propuestos para esta categoría societaria son superiores, en tanto estas sociedades deben cumplir formal y sustantivamente con la presentación de reportes, así como incorporar a su estructura organizativa y de gobernanza corporativa una política de transparencia omnicomprensiva a todos los órganos y esferas de la empresa.

Por un lado, las sociedades de beneficio e interés colectivo deben "presentar reportes anuales a los accionistas y publicar los mismos en Internet para que sean de acceso público" (Halbert, 2015, p. 43). Es decir, cada año la sociedad está obligada por ley a hacer de público conocimiento un reporte anual integral, el que incluya la información económica, social y medioambiental de sus operaciones y actividades. 
Diversas legislaciones establecen que estas sociedades "deben poner a disposición del público un informe que detalla su desempeño social y ambiental" (Abramovay, 2013, p. 23). Este informe debe ser elaborado por un tercero que mida un estándar de las operaciones económicas, sociales y medioambientales de la sociedad, así como la consecución del propósito de beneficio. Es importante resaltar que el tercero independiente no tiene necesariamente porque ser B Lab y puede elegirse cualquier otra herramienta de rendición de cuentas para empresas como por ejemplo los mecanismos de la Organización Internacional para la Estandarización (ISO) o certificadoras privadas e independientes.

Este elemento se convierte en esencial en tanto se quiere que las sociedades de beneficio e interés colectivo tengan un impacto concreto en la realidad y respeten la voluntad plasmada en su acto constitutivo al definir un propósito de beneficio social o medioambiental. Asimismo, esta medición se convierte en un diagnóstico de resultados para los accionistas, directores, administradores y gestores en general de la sociedad. El mismo permite también la determinación de responsabilidades de cara a las decisiones y los resultados de la sociedad en cuanto al cumplimiento de su objeto social y su propósito de beneficio.

Por ello, "este estándar se constituye en el cómo mínimo o en la guía para saber que se está caminando por el camino correcto hacia la consecución del objeto de beneficio público general" (Roncancio, 2013, p. 138). La mención de la obligatoriedad de las sociedades de beneficio e interés colectivo a este tipo de evaluaciones por parte de terceros es común en distintas legislaciones; sin embargo, se limita a establecer tal obligación sin brindar una descripción detallada de quién o cómo debe evaluar a la sociedad.

Esta obligatoriedad es también coherente con los principios de transparencia organizacional que toda sociedad de beneficio e interés colectivo debe tener. Por ello, el Informe Anual de Beneficio descrito anteriormente y presente en el modelo de legislación de B Lab señala que las características generales que debe reunir el estándar evaluado por un tercero hacen que el mismo sea "integral, creíble, independiente y transparente" (B Lab, The Model Legislation, 2016). 


\section{Transparencia organizacional}

La transparencia en las sociedades de beneficio e interés colectivo obedece a dos objetivos. Por un lado, permitirá a la persona jurídica autorregularse en sus operaciones y actividades con la finalidad de tomar las mejores decisiones, las cuales deberán ponderar sus efectos a los grupos de interés antes mencionados y tener en cuenta la consecución del propósito de beneficio social o medioambiental. Por otro lado, "es de prever que esta herramienta de revelar información facilitará una mayor inversión en sociedades de beneficio e interés colectivo y mejorará la lealtad del consumidor, al permitirle diferenciar una empresa con un verdadero propósito de una empresa con una buena estrategia de márketing" (Halbert, 2015, p. 43). En tal sentido, mediante la publicación y divulgación de reportes anuales, la sociedad civil y los mismos actores y grupos de interés tendrán la información disponible para medir los resultados de la persona jurídica y contrastarlos con la realidad.

Por otro lado, es importante considerar este elemento esencial de manera extensiva, en tanto la transparencia debe estar presente en todos los ámbitos organizativos de las sociedades de beneficio e interés colectivo. Internamente, el principio de transparencia debe traducirse en una comunicación permanente entre los órganos sociales y la fuerza de trabajo de la sociedad. Externamente, las relaciones de la sociedad y sus gestores para con los diversos grupos de interés con los que la misma guarda relación, deben cumplir con este elemento esencial, brindando información verídica y comprensible de manera oportuna.

La transparencia en las sociedades de beneficio e interés colectivo es un deber de todos los gestores involucrados en la misma y debe estar comandada por la ley así como plasmada en el estatuto de la sociedad. Es este documento el que debe detallar cualquier intención adicional de los accionistas que involucren ciertas prácticas concretas de transparencia o medidas específicas que corroboren distintos aspectos organizativos como la toma de decisiones gerenciales, asignaciones salariales, implementación de políticas de gobernabilidad corporativa, entre otros.

\subsubsection{Organizaciones promotoras de las Sociedades BIC}

Las sociedades de beneficio e interés colectivo y las Empresas B son promovidas por la organización sin fines de lucro B Lab y por organizaciones promotoras vinculadas a B Lab alrededor del mundo, como Sistema B Internacional y sus ramas locales. 


\subsubsection{B Lab}

B Lab es una persona jurídica sin fines de lucro constituida en Estados Unidos de América en el año 2006 por los emprendedores Jay Coen, Bart Houlahan y Andrew Kassoy. Luego de su experiencia en AND 1, estos emprendedores decidieron difundir su modelo de negocios e impactar a la mayor cantidad de empresas.

Por ello, B Lab se creó con dos objetivos principales. Por un lado, para certificar empresas con buenas prácticas corporativas, sociales y medioambientales. Por otro lado, para promover el surgimiento de sociedades de beneficio e interés colectivo en diferentes legislaciones. "Desde su fundación en el 2006 ha liderado la expansión de tanto la Certificación B y la legislación de sociedades de beneficio, guiado por un principio de asesorar al sector empresarial de elevar su propósito social y la rendición de cuentas, estableciendo como eslogan: no ser las mejores del mundo sino ser las mejores para el mundo" (Bromberg, 2016, p. 160).

\section{B Impact Assessment}

Como primer pilar fundamental, B Lab diseñó el 'B Impact Assessment', proceso de certificación que da origen al concepto previamente analizado de Empresas B Certificadas y precursor de las Sociedades de Beneficio e Interés Colectivo.

El 'B Impact Assessment' es un método integral de certificación a las personas jurídicas que realicen actividad económica y repartan utilidades a sus accionistas y que reúnan "altos estándares de desempeño social y ambiental, y, como consecuencia de ello, tienen acceso a un portafolio de apoyo y servicios especializados, entre ellos: ayuda con el márketing, ventas, recaudación de fondos, ahorro de dinero, acceso a la tecnología, talento y experiencia que ofrece la comunidad de Empresas B Certificadas". (Roncancio, 2013, p. 142). Es importante recalcar que estas no tienen necesariamente que tener la categoría jurídica societaria de Sociedades de Beneficio e Interés Colectivo.

El crecimiento de este método ha sido exponencial en los últimos años y ha creado una cultura de sostenibilidad y transparencia empresarial en diversas regiones y países alrededor del mundo. "B Lab estableció la Certificación B en el año 2007 como un estándar evaluado por terceros para examinar el propósito de beneficio público general o específico liderado por una empresa. Para el año 2014, empresas de 60 industrias distintas y en más de 30 países del mundo han sido certificadas" (Bromberg, 2016, p. 161). 
La certificación se obtiene a través de un proceso integral que permite analizar diversos aspectos de la persona jurídica y evaluar objetivamente el cumplimiento del propósito de beneficio, así como de aprobar satisfactoriamente otras áreas como sostenibilidad y transparencia que permita su declaración como Empresa B Certificada. “Realizar el 'B Impact Assessment' no tiene ningún costo y se encuentra abierto a todo tipo de empresa, para utilizarlo como herramienta de benchmarking o comparación, o de seguimiento al desempeño integral social y ambiental de la empresa, inclusive si no desea convertirse en Certified B Corp” (Roncancio, 2013, p. 143).

El 'B Impact Assessment' sigue una serie de pasos establecidos por B Lab, los cuales constan sintetizados en la tabla a continuación:

\begin{tabular}{|c|c|c|}
\hline \multicolumn{3}{|c|}{ Tabla 3. B Impact Assessment } \\
\hline Paso & Descripción & Medio \\
\hline Primer Paso & $\begin{array}{l}\text { La persona jurídica debe completar una } \\
\text { evaluación inicial que evalúa principalmente el } \\
\text { impacto de sus operaciones y acciones en sus } \\
\text { distintos grupos de interés. }\end{array}$ & $\begin{array}{l}\text { Evaluación en } \text { Internet } \\
\text { según cuestionario } \\
\text { adaptativo. }\end{array}$ \\
\hline Segundo Paso & $\begin{array}{l}\text { B Lab revisará la evaluación inicial con la persona } \\
\text { jurídica con la finalidad de evitar distintas } \\
\text { interpretaciones de las preguntas y entender las } \\
\text { circunstancias y prácticas específicas de la misma. }\end{array}$ & $\begin{array}{l}\text { Comunicación por } \\
\text { correo electrónico y } \\
\text { llamadas telefónicas de } \\
\text { entrevistas } \\
\text { seguimientos. }\end{array}$ \\
\hline Tercer Paso & $\begin{array}{l}\text { En caso la persona jurídica obtenga al menos } 80 \\
\text { puntos de } 200 \text { puntos en total, B Lab solicitará a } \\
\text { la misma documentación de respaldo de entre } 8 \text { y } \\
12 \text { preguntas elegidas aleatoriamente. }\end{array}$ & $\begin{array}{l}\text { Comunicación por } \\
\text { correo electrónico y } \\
\text { envío de documentación } \\
\text { por medio virtual. }\end{array}$ \\
\hline Cuarto Paso & $\begin{array}{l}\text { B Lab solicitará a la persona jurídica a entregar } \\
\text { información confidencial y sensible sobre } \\
\text { cualquier práctica, multa o sanción que podría } \\
\text { afectar la consecución del propósito de beneficio } \\
\text { social o medioambiental. }\end{array}$ & $\begin{array}{l}\text { Comunicación por } \\
\text { correo electrónico, } \\
\text { entrevistas telefónicas y } \\
\text { envío de } \\
\text { documentación. }\end{array}$ \\
\hline
\end{tabular}

Una vez la persona jurídica complete los pasos antes descritos pertenecientes al 'B Impact Assessment', el directorio de B Lab revisará el expediente de la compañía, el 
cual comprende los resultados de la evaluación por Internet, las llamadas telefónicas de seguimiento y la documentación enviada para decidir si otorgar o no la Certificación B.

En caso de otorgar la Certificación B, la persona jurídica deberá comprometerse a reformar su Estatuto, en caso de no ser una sociedad de beneficio e interés colectivo, e insertar modificaciones en una serie de artículos. Asimismo, deberá firmar un acuerdo con B Lab así como cancelar las tarifas de certificación como nuevo miembro de la Comunidad B.

Con la finalidad de mantener los altos estándares que distinguen al 'B Impact Assessment' y a B Lab, así como a las empresas que conforman la Comunidad B, “cerca del 10\% de las empresas son objeto de una auditoría con el fin de mantener la autenticidad y el valor de ser una Certified B Corp, que además sirve para verificar la exactitud de cada respuesta en la 'B Impact Assessment'” (Roncancio, 2013, p. 144). Por ello, los puntajes obtenidos en la certificación pueden ser ajustados luego de una auditoría, y en caso de encontrar serias divergencias entre la realidad y las respuestas evaluadas, la certificación puede ser eventualmente revocada.

En caso la empresa no sea auditada o sea auditada y mantenga su certificación vigente, la misma deberá ser renovada cada dos años "ya que las prácticas y circunstancias de la empresa pueden variar con el tiempo" (Bromberg, 2016, p. 161). Con el objetivo de apoyar en la re certificación y promover la mejora continua de las Empresas B Certificadas, B Lab brinda asesoría en distintos aspectos de la evaluación para insertar o profundizar cambios en la organización y mejorar el puntaje en la siguiente evaluación.

Asimismo, en caso una persona jurídica haya completado los cuatro pasos y no haya obtenido la certificación, B Lab brinda asesoría corporativa para trabajar en la inserción en la empresa de los principios propios de las Empresas B.

Además de los pasos establecidos explicados líneas atrás, es importante entender qué evalúa este proceso de certificación. El 'B Impact Assessment' está dividido en áreas programáticas que deben ser respondidas con gran honestidad por parte de la persona jurídica, quien luego deberá presentar pruebas de algunos puntos específicos evaluados. Las áreas programáticas evaluadas son: (i) Gobierno corporativo; (ii) Prácticas laborales; (iii) Prácticas con la comunidad, y (iv) Medio ambiente. La siguiente tabla indica las áreas programáticas evaluadas, así como sus principales características: 


\begin{tabular}{|c|c|c|}
\hline Área programática & Descripción & Preguntas \\
\hline $\begin{array}{l}\text { Gobierno } \\
\text { corporativo }\end{array}$ & $\begin{array}{l}\text { Esta área evalúa la transparencia y } \\
\text { rendición de cuentas de la persona } \\
\text { jurídica así como el funcionamiento } \\
\text { de sus órganos y proceso de toma de } \\
\text { decisiones. }\end{array}$ & $\begin{array}{l}\text { Las preguntas están dirigidas al } \\
\text { contacto de la persona jurídica con sus } \\
\text { grupos de interés, así como la } \\
\text { información compartida con estos. }\end{array}$ \\
\hline Prácticas laborales & $\begin{array}{l}\text { Esta área examina la relación de la } \\
\text { persona jurídica con sus trabajadores } \\
\text { o fuerza de trabajo. Su interés es } \\
\text { medir objetivamente el trato hacia } \\
\text { estos así como las políticas de la } \\
\text { organización con respecto a } \\
\text { beneficios, compensaciones y } \\
\text { capacitaciones. }\end{array}$ & $\begin{array}{l}\text { Las preguntas están dirigidas a dar a } \\
\text { entender el ambiente de trabajo y la } \\
\text { cultura organizacional de la persona } \\
\text { jurídica. Asimismo, se quiere entender } \\
\text { la relación entre la administración y } \\
\text { los trabajadores en cuanto a } \\
\text { comunicación, flexibilidad laboral y } \\
\text { prácticas de salud y seguridad en el } \\
\text { trabajo. }\end{array}$ \\
\hline $\begin{array}{l}\text { Prácticas con la } \\
\text { comunidad }\end{array}$ & $\begin{array}{l}\text { Esta área evalúa el impacto de la } \\
\text { persona jurídica en la comunidad con } \\
\text { la que interactúa. Por un lado, recaba } \\
\text { información sobre la relación entre la } \\
\text { organización y sus proveedores. Por } \\
\text { otro lado, evalúa las políticas de la } \\
\text { persona jurídica en cuanto a } \\
\text { diversidad y presencia en la } \\
\text { comunidad. }\end{array}$ & $\begin{array}{l}\text { Las preguntas están dirigidas a } \\
\text { demostrar cómo el propósito de } \\
\text { beneficio social o medioambiental } \\
\text { está orientado a resolver un problema } \\
\text { específico. Además, quiere medirse } \\
\text { las prácticas de caridad de la sociedad } \\
\text { en relación a la comunidad inmediata } \\
\text { que la rodea. }\end{array}$ \\
\hline Medio ambiente & $\begin{array}{l}\text { Esta área examina el desempeño de la } \\
\text { sociedad en cuanto a la protección } \\
\text { directa e indirecta del } \\
\text { medioambiente. Se quiere conocer } \\
\text { qué materiales y recursos se utilizan } \\
\text { para el cumplimiento del objeto } \\
\text { social, así como el uso de energía y } \\
\text { emisión de gases contaminantes en } \\
\text { cualquier parte del proceso } \\
\text { productivo. }\end{array}$ & $\begin{array}{l}\text { Las preguntas están dirigidas a medir } \\
\text { el desempeño medioambiental de la } \\
\text { persona jurídica así como sus prácticas } \\
\text { diarias en todo ámbito de sus } \\
\text { operaciones. Las mismas comprenden } \\
\text { sus prácticas generales, su proceso } \\
\text { productivo, su uso de recursos } \\
\text { naturales y el desempeño de sus } \\
\text { transportistas y proveedores. }\end{array}$ \\
\hline
\end{tabular}


Como puede observarse en la descripción y en las preguntas que cada área programática presenta, el 'B Impact Assessment' es un proceso de certificación integral que tiene por objetivo conocer aspectos multidisciplinarios de la organización, así como sus políticas internas y externas que tengan repercusión en los distintos grupos de interés que la misma pueda afectar.

\section{Promoción de iniciativas legislativas}

Como segundo pilar fundamental, B Lab se encarga activamente de promover iniciativas legislativas a nivel global que permitan la regulación nacional de sociedades de beneficio e interés colectivo. En tal sentido, esta organización tiene como una de sus finalidades principales el promover los principios de las Empresas B Certificadas y convertirlos en ley, para que los mismos sean obligatorios para aquellos accionistas que así lo decidan.

En su página web, B Lab enlista la "promoción de una misión alineada a utilizar estructuras corporativas, como la sociedad de beneficio e interés colectivo, para que existan negocios de alto impacto y larga duración que tengan un propósito social o medioambiental" (B Lab, 2016) como una de sus finalidades.

B Lab está especialmente preocupada y concentrada en promover el modelo híbrido de hacer negocios. "La legislación distingue entre personas jurídicas con ánimo de lucro, que protegen el interés privado de los accionistas, y personas jurídicas sin fines de lucro, que buscan el interés público y general. Las nuevas empresas, llamadas empresas 'híbridas' o empresas 'con propósito', combinan ambos propósitos: el ánimo de lucro con la búsqueda del interés general" (Abramovay, 2013, p. 22).

Es por ello que es esta organización, paralelamente con la creación del B Impact Asssessment, trabajó arduamente con la creación de una legislación modelo que ha sido replicada en diversos estados de Estados Unidos de América y también en diversas legislaciones de América Latina y alrededor del mundo. Este modelo legislativo ha sido trabajado entre B Lab y los abogados pro bono de la firma Drinker, Biddle \& Reath LLP y el mismo se encuentra disponible en la página web BenefitCorp.net, portal de B Lab para promover exclusivamente la adopción de esta categoría jurídica societaria en los ordenamientos jurídicos en los que no existe. 
El modelo legislativo recomendado por B Lab cuenta con cuatro subcapítulos, los cuales se identifican claramente con los elementos esenciales de las sociedades de beneficio e interés colectivo. En primer lugar, establece las provisiones preliminares por las cuales se crea la categoría societaria y se especifican las definiciones técnicas necesarias. En segundo lugar, establece el propósito de beneficio, el cuál debe estar presente en el estatuto social de la persona jurídica que adopte esta categoría societaria. En tercer lugar, amplía los deberes y las protecciones de los directores con la finalidad de establecer un estándar de conducta para los directores, que permita considerar el impacto de sus decisiones en los grupos de interés. En cuarto lugar, establece las políticas de transparencia que deberán regir en este tipo de organizaciones y norma la preparación y publicación del reporte anual obligatorio, así como establece que el mismo debe ser elaborado según el estándar determinado por un tercero.

La legislación modelo promovida por B Lab es la principal herramienta por la cual esta organización promueve la adopción de las sociedades de beneficio e interés colectivo. Como puede observarse, la misma reúne los elementos esenciales de esta categoría. B Lab indica que sus mayores ventajas son la experiencia, consistencia, conformidad y adaptabilidad económica que hacen del cuerpo normativo un excelente punto de partida para aquellas legislaciones que tienen modelos societarios tradicionales. En el siguiente capítulo, podrá observarse la influencia de esta legislación modelo en distintas legislaciones.

\subsubsection{Sistema B Internacional}

Sistema B Internacional es en América Latina la organización paralela a B Lab en Estados Unidos. Sus fundadores son Pedro Tarak, Juan Pablo Larenas, Gonzalo Muñoz y María Emilia Correa, cuyo interés es "promover fuerzas económicas para la transición hacia las nuevas economías y un desarrollo sostenible en Sur América" (Abramovay, 2013, p. 25). Sistema B Internacional hace referencia a las nuevas economías como aquellas en las que se fomenta un cambio social rentable, el que permita la toma de decisiones sustentables para los grupos de interés conexos con la actividad económica realizada por una empresa.

Como los fundadores de B Lab, los fundadores de Sistema B Internacional tomaron la iniciativa de emprender la conformación de esta organización luego de experiencias personales y de conocer del concepto de las Empresas B Certificadas en 
Estados Unidos. Esta experiencia es similar a la vivida por Jay Coen, Bart Houlahan y Andrew Kassoy, en tanto estos emprendedores latinoamericanos sintieron "frustración de tratar de promover cambios al interior de empresas tradicionales y encontrarse con la limitación de la necesidad de privilegiar el rendimiento financiero de corto plazo por sobre la búsqueda de una mejor sociedad" (Abramovay, 2013, p. 25). Por ello, Sistema B Internacional se erige hoy en día como el referente latinoamericano que tiene como finalidad la promoción regional de la Certificación B y de las sociedades de beneficio e interés colectivo.

Sistema B Internacional se encarga de promover y asesorar a las personas jurídicas que así lo deseen en el proceso de Certificación B, con la finalidad que las mismas sean evaluadas por el B Impact Assessment. Además, trabaja constantemente en la promoción de este modelo de negocio tanto en el sector público como el sector privado con la finalidad de introducir iniciativas legislativas locales de manera progresiva, como se ha dado en países como Argentina, Chile y Colombia.

Hoy en día, Sistema B Internacional define su misión como "construir un ecosistema favorable para fortalecer empresas que utilizan la fuerza de mercado para dar solución a problemas y ambientales: las Empresas B" (Sistema B, 2016). Con la finalidad de cumplirla y promover los pilares fundamentales de B Lab, esta organización regional ha logrado reunir directorios y equipos de líderes en Argentina, Brasil, Chile, Colombia, Perú y Uruguay. Además, cuenta con un equipo para la región compuesto de personas de los países antes mencionados.

En el Perú, el directorio está conformado por Baltazar Caravedo, director del Centro de Liderazgo de la Universidad del Pacífico, Jorge Caillaux, Presidente de la Sociedad Peruana de Derecho Ambiental, Andrea Cilloniz y María Paz Cigarán. 


\section{CAPÍTULO III: DESARROLLO LEGISLATIVO EN LAS AMÉRICAS}

\subsection{Estados Unidos de América}

La codificación de las sociedades de beneficio o "Benefit Corporations" en los Estados Unidos de América ha sido progresiva y sostenida desde el año 2010. Ello, se da en respuesta a los esfuerzos de diversos grupos de interés, en especial B Lab, y la promoción de un modelo de legislación, redactado, entre otros, por William H. Clark, Jr. Este modelo ha sido implementado en diversos estados, conservando en todos ellos, un texto similar a pesar de algunas modificaciones prácticas introducidas por algunas legislaturas estatales.

Asimismo, la inclusión de esta categoría jurídica societaria en la legislación comercial de 30 estados de los Estados Unidos y el Distrito de Columbia, es una respuesta al interés de consumidores e inversionistas. Por un lado, "aproximadamente 68 millones de consumidores estadounidenses muestran una preferencia en sus decisiones de compra basados en un sentido de responsabilidad social y medioambiental" y también porque "recientes estudios muestran que, cuando el precio y la calidad son similares, $87 \%$ de los consumidores preferirá una marca que es socialmente responsable" (Halbert, 2015, p. 41). El creciente interés de los consumidores norteamericanos ha puesto en el tablero, tanto de los emprendedores como de los negocios consolidados, la inclusión de un propósito social que forme parte de los valores empresariales y tenga una conexión sinérgica con la consecución del objeto social en la venta de bienes o en el proveer servicios.

Por otro lado, los inversionistas han sido testigos del cambio de paradigma en la manera de hacer negocios de los últimos años. "Las inversiones socialmente responsables han crecido en los últimos diez años hasta representar el 10\% de los activos administrados en los Estados Unidos, alrededor de US\$ 2 trillones" (Halbert, 2015, p. 41). Tales factores han sido determinantes para la rápida difusión de las sociedades de beneficio en los Estados Unidos en tanto los actores más importantes del mundo corporativo - los consumidores e inversionistas - se encuentran receptivos a un nuevo modelo de hacer 
negocios, el cual, de manera conjunta a la generación de utilidades y riqueza personal, tiene un impacto social o medioambiental.

\subsubsection{Maryland}

Maryland fue el primer estado de los Estados Unidos de América en codificar en sus leyes societarias la figura jurídica de la sociedad de beneficio. "Luego de un intenso lobbying por B Lab y sus promotores en varios estados, Maryland y Vermont fueron los primeros estados en aprobar legislación sobre las sociedades de beneficio, facilitando así nuevas estructuras corporativas que permiten la creación de beneficios sociales y valor para sus accionistas" (Richardson, 2015, p. 306).

En el desarrollo de la presente sección, se hará mención a las características de la ley 690, del estado de Maryland, pionera en los Estados Unidos como la ley que regula la constitución y existencia de las sociedades de beneficio, así como aquella que regula la posible transformación de una persona jurídica constituida bajo otra figura societaria a la innovadora figura de la sociedad de beneficio.

La ley 690 fue aprobada por el Senado de Maryland el 13 de abril de 2010 y la misma surtió efectos a partir del 1 de octubre del mismo año. En la ley 690, se deja expresa constancia que la misma tiene "el objetivo de autorizar a una corporación elegir tener la categoría societaria de sociedades de beneficio por medio de la modificación de su estatuto social o la creación de una nueva persona jurídica" (Senate Bill 690, p. 1). Asimismo, establece que el estatuto social de la sociedad de beneficio deberá identificar además del objeto social, un propósito que conlleve beneficios públicos específicos para la sociedad o el medio ambiente.

El estado de Maryland, al ser pionero en la redacción y aprobación de legislación concerniente a las sociedades de beneficio, permitió que las mismas dentro de su jurisdicción puedan organizarse de manera adecuada. Esta organización responde a su naturaleza orgánica y la misma tiene la finalidad de asignarle igual importancia tanto al objeto social como el propósito de beneficio de las mismas. El rápido despertar del sector empresarial y emprendedor en Maryland fue un ejemplo para las demás jurisdicciones estatales en Estados Unidos de la viabilidad económica, social y medioambiental de las sociedades de beneficio. 
Tal circunstancia es importante en cuanto, "las especificaciones en la ley de Maryland son similares a las provisiones incluidas en la legislación redactada para los otros estados que también regulan a las sociedades de beneficio" (Leclair, 2014, subtema 3.2). El modelo de la ley 690 se ha replicado en la mayoría de los estados de los Estados Unidos, en tanto su sucesiva codificación ha sido siempre promovida por B Lab y por el equipo jurídico que ha desarrollado el modelo de legislación. Las leyes se diferencian principalmente en aspectos de forma en cuanto a su pertenencia a los diferentes cuerpos normativos comerciales de los diferentes estados.

En tal sentido, es importante analizar algunas de las definiciones más importantes que se exponen en la Ley 690 en tanto las mismas influenciaron a las normas que regulan a las sociedades de beneficio en múltiples estados de los Estados Unidos y han sido exportadas tanto de un estado a otro, como a varios de los países que están adoptando en su normativa legal el concepto jurídico societario de las sociedades de beneficio.

- Beneficio público general: la Ley 690 especifica que toda sociedad de beneficio debe tener un objetivo de beneficio público general, el cual "signifique un impacto material y positivo en la sociedad y en el medio ambiente, cuyo estándar será medido por terceros a través de actividades que promuevan la combinación de beneficios públicos específicos” (Senate Bill 690, p.2).

- Beneficio público específico: la ley detalla siete provisiones entre las que se incluyen el proveer a individuos o comunidades con productos o servicios que los beneficien; la promoción de oportunidades económicas a través de la creación de empleos; la preservación del medio ambiente; la mejora de la salud pública; la promoción de las artes y ciencias así como una cláusula general por la cual las sociedades de beneficio pueden tener objetivos diferentes siempre que estos tengan un propósito que generen beneficios sociales o medioambientales.

- Estándar evaluado por terceros: quizás una de las características más revolucionarias que aportó la Ley 690 al derecho societario del estado de Maryland es el mandato legal por el cual “el estándar evaluado por terceros significa que un tercero deberá definir, reportar y evaluar las mejores prácticas en la organización societaria y los resultados sociales y medioambientales" (Senate 
Bill 690, p. 3). Por ello, la norma le otorga a una institución la capacidad de evaluar tanto el objeto social como el propósito de beneficio, así como la transparencia corporativa y la información contable disponible.

A pesar de su reciente implementación en el ordenamiento jurídico del estado de Maryland, las sociedades de beneficio pueden ser examinadas gracias a un estudio realizado por la Escuela de Negocios Robert H. Smith de la Universidad de Maryland. El mismo, fue publicado en el año 2013 y tiene por objetivo responder algunas interrogantes comunes como: ¿cuántas sociedades de beneficio se crearon en Maryland en los tres primeros años desde su codificación? y ¿cuáles son los giros de negocio a los que se dedican las sociedades de beneficio?

Asimismo, los investigadores tuvieron como meta el entregar al gobierno del estado de Maryland un análisis integral de la nueva categoría jurídica societaria y su impacto en el sector privado, así como una sugerencia de incentivos que el gobierno podría implementar con la finalidad de estimular una mayor presencia de sociedades que deseen operar como sociedades de beneficio. Para ello, los investigadores "trabajaron en identificar una manera de medir el efecto de la nueva legislación en el estado e identificar características comunes de las organizaciones participantes: sus incentivos (verdaderos o percibidos) para elegir la categoría de sociedad de beneficio y aquellos resultados cuantificables que permitan a otras organizaciones implementar las mejores prácticas dentro de su estructura" (Castro, 2013, p. 4).

Los resultados del estudio fueron reveladores para el cambio organizacional que ha generado la inserción de esta categoría societaria híbrida en la legislación societaria de Maryland. En primer lugar, los investigadores encontraron que aquellas personas jurídicas constituyéndose o transformándose a sociedades de beneficio ya consideran que su negocio o idea de negocio tiene un propósito social intrínseco, el cual está "claramente consignado en la visión de la compañía, así como el núcleo de sus valores y su misión" (Castro, 2013, p. 5). Esta conclusión permite explicar el rápido tránsito a través de la transformación societaria permitida por la Ley 690 por el cual, personas jurídicas se transformaron en sociedades de beneficio en tanto en su actividad, además de la presencia del objeto social, se encontraba un propósito de beneficio cuya importancia era equiparable para los accionistas al desarrollo de la actividad económica. Asimismo, demuestra la utilidad de la personería jurídica híbrida, en tanto las sociedades de 
beneficio tiene fines de lucro, reparte utilidades, pero su fin último trasciende la maximización de lucro en tanto el propósito de beneficio social o medioambiental cobra una importancia institucional de gran relevancia.

En segundo lugar, los investigadores llegaron a la conclusión que el auge de las sociedades de beneficio en el estado había generado la oportunidad de promover distintas iniciativas conexas y dependientes a la nueva legislación, como por ejemplo, el reconocimiento y contribución de la comunidad en la sociedades de beneficio, el centrar las estrategias de marketing tanto a la venta del bien o servicio así como también a la consecución del propósito social. Asimismo, el estudio demostró la existencia de la necesidad generada por estas nuevas sociedades de beneficio que requieren servicios especializados a su categoría empresarial. El surgimiento de este nuevo modelo de negocios ha creado una importante demanda multidisciplinaria por la cual abogados, publicistas, ingenieros, funcionarios administrativos y toda una gran variedad de profesionales entiendan el concepto de una sociedad de beneficio y su visión económica, social y medioambiental, con la finalidad que la misma se desenvuelva en el mercado de acuerdo a su naturaleza híbrida.

En tercer lugar, la investigación llegó a la conclusión que los emprendedores y accionistas no tenían como una razón determinante o principal, para constituirse como una sociedad de beneficio, el tener incentivos tributarios. De la encuesta realizada a las 39 sociedades de beneficios existentes en Maryland en la época en que se desarrolló la investigación, "38\% estuvo fuertemente en desacuerdo en que se haya elegido tal categoría societaria por razones de flexibilidad tributaria, 38\% estuvo en desacuerdo y 12 \% de acuerdo, así como 12\% en posición neutral" (Castro, 2013, p. 17). La importancia de esta conclusión recae en que los promotores de la legislación, B Lab y otros grupos de interés, tienen como primera finalidad la de codificar un modelo societario que permita la existencia del fin lucrativo con un propósito de beneficio como una respuesta al cambio de paradigma de hacer negocios, el cual está influenciado por la situación social y medioambiental del mundo, sin la necesidad de un beneficio tributario inherente a la categoría societaria.

Finalmente, los investigadores consignaron recomendaciones con la finalidad de posicionar a las sociedades de beneficio como una categoría societaria más atractiva y eficiente. Las recomendaciones de la investigación pueden resumirse en cuatro ejes principales: (1) Creación de incentivos, no necesariamente económicos, entre los que se encuentra una mayor exposición mediática de la categoría jurídica así como el 
reconocimiento de la misma en trámites gubernamentales; (2) Formalización del proceso de certificación, con la finalidad de estandarizar las certificaciones y los puntajes obtenidos por las sociedades de beneficio; (3) Comunicación con los grupos de interés, con la finalidad de promover el propósito social y el bien o servicio vendido y crear una red de servicios multidisciplinarios especializados en sociedades de beneficio, ya sean legales, de publicidad, de alta gestión, entre otros, y, (4) Inclusión de las sociedades de beneficio en las estrategias de desarrollo económico de la región a través de la implementación de la categoría societaria en nuevos emprendimientos y personas jurídicas.

La investigación realizada por la Universidad de Maryland fue decisiva para la posterior modificación y discusión del proyecto de ley estandarizado de las sociedades de beneficio en diferentes estados de los Estados Unidos, en tanto la misma dio luces en cuanto a la implementación de la legislación en nuevas personas jurídicas y en personas jurídicas existentes que decidieron transformarse a la categoría jurídica de sociedades de beneficio. Asimismo, la investigación indicó la tendencia a la creación de una cadena de proveedores especializados que tienen como finalidad dar un soporte especial y específico a las sociedades de beneficio.

Con un creciente mercado de personas jurídicas que eligen constituirse o transformarse aplicando la categoría societaria de las sociedades de beneficio, Maryland se ha consolidado como el primer estado de los Estados Unidos de América en legislar y operar bajo esta forma societaria. En tal sentido, estas sociedades deben cumplir con los requerimientos estatales impuestos por la Ley 690 por la cual las sociedades de beneficios deben tener en sus estatutos sociales una mención expresa a la categoría jurídica, así como al objeto social y al propósito social o medioambiental.

Asimismo, en la práctica, este propósito social o medioambiental debe ser tangible en la realidad y sus fondos provenir de parte de los ingresos de la consecución del objeto social. Consecuentemente, para la realización de tanto el objeto social como el propósito social, "los directores de la sociedad deben considerar el efecto de cualquier acción o decisión en sus accionistas, empleados o fuerza de trabajo, el interés de los consumidores y de los beneficiarios del beneficio público, la comunidad y sociedad que rodea el lugar del desempeño de sus funciones, y finalmente, la sociedad debe generar y publicar un reporte anual en donde se consignen las utilidades obtenidas así como el impacto del beneficio público en consecución del propósito social" (Stockwell, 2016). 
El posicionamiento de Maryland como el estado precursor de las sociedades de beneficio ha sido fundamental para la posterior diseminación de la categoría societaria y el modelo de la ley a otros estados de los Estados Unidos y su posterior internacionalización. Jamie Raskin, profesor universitario de Derecho Constitucional y senador del estado de Maryland, en un artículo publicado en la revista The Nation identificó el cambio de paradigma que conlleva el movimiento legal y empresarial de las sociedades de beneficio:

"En un sentido político, el surgimiento popular de las sociedades de beneficio cambiará la manera en que las personas piensan acerca de cómo hacer negocios. Podemos tener una economía de libre mercado sin tener una sociedad de mercado, y podemos tener corporaciones prósperas que actúen con consciencia. Los sindicatos de trabajadores y las personas jurídicas sin fines de lucro deberían promover este modelo de negocio - verde, local, progresista, emprendedor, atento a las necesidades de la comunidad - como una alternativa a un sistema económico controlado por enormes corporaciones subsidiadas por el Estado, las cuales son muy grandes para fallar y cuyos ejecutivos muy ricos para imputar por sus delitos" (Raskin, 2011).

\subsubsection{California}

California, caracterizado por ser un estado que propicia a través de su legislación la constitución de personas jurídicas para nuevos emprendimientos y aventuras empresariales, es otro de los treinta estados de los Estados Unidos de América que han implementado la legislación acorde a las sociedades de beneficio. La ley fue aprobada el 9 de octubre de 2011 y entró en vigencia el 1 de enero de 2012. Mediante el Assembly Bill No. 361 se añadió un treceavo capítulo, relativo a las sociedades de beneficio, a la División Tercera del Título Primero del Código de Sociedades.

El mismo continúa el modelo de legislación de sociedades de beneficio común en Estados Unidos y por ello hace énfasis en su capítulo 3 y capítulo 4 a los pilares fundamentales del concepto de las sociedades de beneficio, la rendición de cuentas y la transparencia, respectivamente.

Por un lado, en cuanto a la rendición de cuentas, la legislación predominante en Estados Unidos, asigna a los directores la responsabilidad de "actuar de buena fe, en la 
manera en la que el director crea que es el mejor interés para la sociedades de beneficio de acuerdo al estándar del hombre razonable en la misma posición en circunstancias similares" (Assembly Bill No. 361, p. 5). Sin embargo, en el caso de las sociedades de beneficio, los directores tienen una responsabilidad adicional, la cual, como menciona Stockwell en el caso de Maryland, se repite en el estado de California, donde además se menciona expresamente que los mismos deberán "considerar los impactos de cualquiera de sus acciones o posibles acciones en (...); (5) el medioambiente local o global; (6) el interés a corto o largo plazo de la sociedades de beneficio, incluyendo beneficios que pudieran resultar para la misma por sus planes a largo plazo y la posibilidad que estos intereses sean mejor atendidos al retener el control de la sociedades de beneficio en vez de vender o transferir su control a otra composición accionaria; (7) la habilidad de la sociedades de beneficio en lograr su objeto social así como su propósito de beneficio social o medioambiental" (Assembly Bill No. 361, p. 5).

El numeral quinto de la ley 361 de California encomienda a los directores la responsabilidad de ponderar los resultados relativos a la consecución del objeto social así como del propósito de beneficio con la potencialidad de su mejora a corto y a largo plazo. Más aún, este numeral encomienda a los directores a evaluar tales factores en el caso de una posible venta o transferencia del control accionario de la sociedades de beneficio, con la finalidad que los objetivos de la misma no se vean perjudicados con tales cambios. Es así que los directores tienen una responsabilidad adicional, la cual está directamente relacionada a la consecución del propósito de beneficio social o medioambiental y su protección ante un eventual cambio en el accionariado.

Por otro lado, en cuanto a la transparencia, el estado de California mantuvo el estándar común en la legislación estadounidense de establecer la obligación a la sociedades de beneficio de elaborar un informe anual detallado a sus accionistas, beneficiarios y terceros interesados. La singularidad del informe recae en la igual importancia a los resultados económicos de la consecución del objeto social así como los resultados relativos al propósito de beneficio social o medioambiental emprendido por las sociedades de beneficio. La ley 361 de California indica que el informe debe mencionar "las maneras en las que la sociedades de beneficio ha conseguido el beneficio público específico consignado en su propósito de beneficio y si se han cumplido los objetivos propuestos para el cumplimiento del mismo" (Assembly Bill No. 361, p. 7). Es así que se delimita la naturaleza jurídica societaria de las sociedades de beneficio como una 
persona jurídica en la cual la coexistencia del objeto social y de propósito de benefício deben ser sinérgicas y transparentes, en tanto una actividad le da sentido a la otra.

\subsubsection{Nueva York}

Así como Maryland y California, el estado de Nueva York adoptó la legislación A4692A correspondiente a las sociedades de beneficio el 12 de diciembre de 2011, la misma que entró en vigencia el 10 de febrero de 2012. Con ello, Nueva York fue el sétimo estado de los Estados Unidos en incluir legislación acerca de la sociedades de beneficio, a través de una enmienda a la Ley de Personas Jurídicas, por la cual se autorizó la incorporación de las sociedades de beneficio, con las mismas características que las aplicadas en el modelo de legislación adoptado por Maryland.

Tal enmienda incluyó el artículo 17 en la Ley de Personas Jurídicas del Estado de Nueva York. En dicho artículo, se define a las sociedades de beneficio, se establece su naturaleza jurídica societaria, los requisitos que debe cumplir para conservar su existencia legal y se establece un claro estándar de conducta para los directores y otros funcionarios, el que sigue la misma línea en todos los estados en los cuales se ha adoptado la legislación de las sociedades de beneficio.

En la promoción de la nueva figura societaria, el estado de Nueva York ha resaltado la versatilidad de las sociedades beneficio, ya que la mismas "puede considerar otros factores y fines más allá de la maximización de la utilidad, sin tener el potencial peligro que sus directores sean imputados por violar sus deberes fiduciarios" (Bjorklund, 2012, primera sección). Los mismos, según la legislación correspondiente a otros tipos societarios en la legislación comercial de Estados Unidos, pueden ser imputados por no destinar el máximo posible de las utilidades a sus accionistas, y así, no cumplir con sus deberes de garantes del patrimonio social y de los intereses de los accionistas.

Asimismo, el gobierno del estado de Nueva York ha indicado oportunamente que, si bien "las sociedades de beneficio tienen un enfoque social y medioambiental, estas no son obras de caridad. Las mismas son personas jurídicas con fines de lucro cuyo objetivo es el ofrecer a emprendedores e inversionistas la opción de crear e invertir en oportunidades de negocios que tengan mayores estándares en sus objetivos corporativos, rendición de cuentas y transparencia" (Bjorklund, 2012, primera sección). 


\subsubsection{Connecticut}

La experiencia positiva en estados de grandes inversiones, como Nueva York y California, han creado un referente importante para otras legislaturas en Estados Unidos, las cuales han insertado en sus leyes comerciales la legislación correspondiente a las sociedades de beneficio de manera tal que su naturaleza híbrida sea ampliamente reconocida y pueda operar tanto el objeto social como el propósito de beneficio. El estado de Connecticut aprobó la Governor's Bill No. 23 el 24 de abril de 2014 y la misma entró en vigencia el 1 de octubre del mismo año.

Si bien, como se mencionó anteriormente, las mismas siguen un modelo de ley el cuál se repite en los estados que cuentan con esta legislación, se han presentado innovaciones recientes, como por ejemplo, las denominadas cláusulas de preservación de la sociedades de beneficio.

El estado de Connecticut insertó una sección en la ley por la cual "una sociedades de beneficio puede, no antes de los veinticuatro meses luego de la fecha de su constitución o transformación, someterse a una cláusula de preservación, enmendado su estatuto, para que el mismo contenga una declaración que la sociedades de beneficio está sometida a dicha cláusula" (Governor's Bill No. 23, p. 6).

Esta novedad legislativa nos hace preguntarnos ¿qué son las cláusulas de preservación? Estas cláusulas permiten a los socios fundadores de la sociedades de beneficio tomar un acuerdo vinculante por el cuál la misma no podrá ser transformada a otra categoría jurídica. Por ello, las cláusulas de preservación se han convertido en la manera más agresiva de defender la naturaleza híbrida de la sociedades de beneficio, así como la coexistencia sinérgica del objeto social y el propósito de beneficio.

La legislación vigente en Connecticut prevé varios casos prácticos en los que la existencia de las cláusulas de preservación cambia la manera en la que las sociedades de beneficio operan en una determinada situación societaria. Por ejemplo, en los siguientes casos:

- Liquidación y disolución de las sociedades de beneficio: en caso una sociedad de beneficio con cláusula de preservación sea liquidada y disuelta, su remanente deberá ser distribuido "únicamente a (1) organizaciones de caridad o (2) otras sociedades de beneficio que cuenten con cláusulas de preservación." (Governor's Bill No. 23, p. 7). Ello se distancia de las normas provistas para sociedades de 
beneficio que no cuentan con esta cláusula, en tanto el remanente disponible se repartiría entre los accionistas luego del cese del objeto social y de la terminación definitiva del propósito de beneficio.

- Fusión de una sociedad de beneficio: en caso una sociedad de beneficio con cláusula de preservación quiera ser parte de una fusión, el proceso de fusión deberá cumplir condiciones establecidas por la Sección Sétima del Governor's Bill No. 23. En ella se indica que "la persona jurídica vigente luego de la fusión deberá ser una sociedad de beneficio que tendrá adoptar una cláusula de preservación" y "las acciones de la sociedad de beneficio partícipe en la fusión se convertirán en un derecho a recibir acciones de aquella nueva sociedad de beneficio" (Governor's Bill No. 23, p. 8). En caso contrario, sin el acuerdo de esta cláusula en los estatutos de las sociedades de beneficio, las mismas pueden fusionarse con otras personas jurídicas y no ser sociedades de beneficio en el futuro.

- Disposición del patrimonio: a diferencia de las sociedades de beneficio que no han adoptado la cláusula de preservación, las que sí lo han hecho "no podrán poner su patrimonio en venta, hipoteca, intercambio o cualquier otra disposición de sus activos, a menos que esta disposición se haga en relación con organizaciones de caridad u otras sociedades de beneficio con cláusulas de preservación, cumpliendo los mínimos de voto necesario" (Govenor's Bill No. 23, p. 8).

Las implicancias de las condiciones especiales adoptadas en el estado de Connecticut demuestran una inclinación sin precedentes en la legislación de las sociedades de beneficio al propósito de beneficio y al fin altruista de las sociedades de beneficio. Sin embargo, la misma cláusula modifica la naturaleza híbrida de las sociedades de beneficio, las cuales por su propia concepción asignan la misma importancia tanto a la finalidad lucrativa y la repartición de un porcentaje de utilidades a sus socios, como la consecución de propósito de beneficio, ya sea este social o medioambiental. 
Aun así, esta cláusula ha brindado una opción a aquellos inversionistas y emprendedores para acogerse a un régimen más estricto que el normado en los otros estados. El periódico local Hartford Courant reportó que Connecticut "es el único estado que permite a los emprendedores sociales asegurar la conservación y transmisión de su persona jurídica a través de los años normando la cláusula de preservación, por la cual pueden retener dicha figura societaria para siempre" (Zhang, 2014). Este es, a la actualidad, la modificación legislativa más profunda hecha en Estados Unidos a la figura societaria de las sociedades de beneficio, brindándole una opción de candado, que si bien puede parecer extrema, es acorde a la voluntad de distintos fundadores y sus objetivos económicos y sociales.

\subsection{América Latina}

América Latina es territorio fértil para el surgimiento y adopción de las sociedades de beneficio como una nueva categoría jurídica. A pesar de la aún casi inexistente regulación legal de las mismas y su naturaleza jurídica en las legislaciones nacionales, el avance de los últimos años ha sido significativo, en tanto numerosas empresas, pequeñas, medianas y grandes, están adoptando los principios de las sociedades de beneficios en Estados Unidos, autorregulándose, con la finalidad de certificarse y llevar a cabo una actividad coordinada entre el objeto social acordado y el propósito de beneficio deseado.

La realidad de América Latina es un factor determinante en la promoción de las sociedades de beneficio en tanto "[e]s imposible avanzar rumbo al desarrollo sostenible en América Latina sin una profunda transformación de los comportamientos empresariales" (Abramovay, 2013, p. 11). La realidad empresarial latinoamericana, cuyos pilares reposan en las industrias extractivas no renovables "refleja consecuencias económicas y financieras: si algunas empresas ganan, pierden el planeta y la sociedad." (Abramovay, 2013, p. 11).

Si bien el fenómeno de las sociedades de beneficio ha tenido una acogida entre empresarios y emprendedores latinoamericanos, es el rol de abogados y juristas informados de los planteamientos económicos, sociales y medioambientales de este tipo de sociedades, el diseñar, según cada legislación nacional, la estrategia más efectiva para el reconocimiento legal de esta categoría jurídica, o, por el momento, de qué manera 
pueden los socios de empresas constituidas bajo otra modalidad societaria, el autorregularse con prácticas alineadas a las sociedades de beneficio.

Con la finalidad de crear un movimiento regional, B Lab ha promovido la creación de organizaciones nacionales que se encarguen de la difusión de las sociedades de beneficio en América Latina, siendo Sistema B la organización latinoamericana líder con operaciones en diversos países de la región. Las organizaciones nacionales, tienen la finalidad de promover el concepto y los valores de trabajo de las mismas en distintos frentes: en el empresariado, en la academia, y en el sector público, este último con la finalidad de crear cambios legislativos que reconozcan la existencia de las sociedades de beneficio.

Sistema B tiene como desafíos estratégicos, en primer lugar, "aumentar el número de empresas B en América Latina, empresas que sean líderes, incidentes, escalables, innovadoras, con impactos demostrables" (Abramovay, 2013, p. 25). Ello responde al objetivo de generar una red latinoamericana de sociedades de beneficio que a su vez, en sus negocios diarios y la consecución de su propósito de beneficio, genere el interés en emprendedores y empresarios sobre esta nueva categoría societaria. Si bien es importante el aumento en cantidad de las sociedades de beneficio, es igual de importante que las mismas se comprometan fundamentalmente a los criterios que dan origen al concepto de las sociedades de beneficio.

En segundo lugar, "apoyar a Empresas B para aumentar su valor económico social y ambiental" (Abramovay, 2013, p. 25). Si bien hay sociedades de beneficio líderes en la industria y comercio, la mayor cantidad este tipo de empresas son emergentes y pueden pasar desapercibidas. En tal sentido, el apoyo a las mismas es fundamental en especial cuando éstas operan bajo tipos societarios determinados legalmente por la legislación comercial según sea el país. Por ello, la adecuación a los principios de beneficio son decisión de cada persona jurídica, y es muy común que en aquellos países cuya legislación comercial no incluye a las sociedades de beneficio, las personas jurídicas que así lo desean se esfuercen en cumplir criterios sugeridos para luego certificarse como Empresas B.

Finalmente, "impulsar un entorno propicio para Empresas B, el ecosistema B, a través de políticas públicas, marcos regulatorios, una industria de inversión de impacto en la academia e investigación que sensibilice a los ciudadanos y consumidores." 
(Abramovay, 2013, p. 25). Los desafíos estratégicos de los promotores de las sociedades de beneficio en América Latina son integrales, en tanto tienen como objetivo promoverlas desde varios frentes, con la finalidad de generar un impacto en la nueva generación de empresarios y empresas que consoliden una plataforma de conocimiento compartido basada en el generar ventas o servicios que en paralelo con el ánimo de lucro, tengan un propósito de beneficio social o medioambiental.

A continuación, se detallará el desarrollo legislativo en algunos países de América Latina en los cuales hay una rápida adopción de los principios inspiradores de las sociedades de beneficio.

\subsubsection{Argentina}

La comunidad empresarial y jurídica que respalda la promoción de las sociedades de beneficio en Argentina es emergente. Recientemente, en el mes de febrero de 2016, "se presentó en la Cámara de Diputados el anteproyecto de ley de Sociedades de Beneficio e Interés Colectivo para definir su presentación formal ante el Congreso" (Comunica RSE, 2016). Dicha presentación convocó a representantes de tanto el sector público como el sector privado, en tanto fue moderado por el Ministerio de Desarrollo Social de la Nación y contó con la asistencia de abogados de diversos estudios jurídicos, así como miembros de Sistema B Argentina.

El anteproyecto de ley sobre Sociedades de Beneficio e Interés Colectivo señala en su artículo primero que se considerarán como estas a "las sociedades constituidas conforme a alguno de los tipos previstos en la Ley General de Sociedades N ${ }^{\circ} 19.550$ y sus modificatorias, cuyos socios además de obligarse a realizar aportes para aplicarlos a la producción o intercambio de bienes o servicios, participando de los beneficios y soportando las pérdidas, se obliguen a generar un impacto positivo social y ambiental en la comunidad" (Sistema B Argentina, 2016, p. 4). El artículo primero delimita la naturaleza jurídica de las sociedades de beneficio e interés colectivo en Argentina, ya que esta categoría societaria puede ser utilizada por personas jurídicas constituidas bajo otros tipos societarios presentes en la legislación argentina, cuyos socios decidan, además, someterse a la consecución de un propósito de beneficio social o medioambiental adicional al objeto social. Este es, sin duda, un anteproyecto de ley diferenciado a aquellos presentes en las Américas, en tanto la persona jurídica no tendría que constituirse 
con este vehículo social sino con algún otro, el cuál además adoptaría los principios de beneficio señalados en la ley que este proyecto generaría.

Más aún, este primer artículo indica que estas sociedades "se regirán por las disposiciones de la presente ley y la Ley General de Sociedades, y en particular por las normas que le sean aplicables según el tipo social que adopten y la actividad que realicen" (Sistema B Argentina, 2016, p. 4). Tal afirmación clarifica la intención de los redactores de la ley, de presentar a esta categoría societaria "de beneficio e interés colectivo" como una característica legal adicional y ajena al tipo societario para aquellas sociedades que decidan someterse además al régimen legal señalado por esta ley.

En los artículos siguientes del anteproyecto, se dejan ver claramente aquellos principios comunes al concepto primigenio de las sociedades de beneficio: el propósito de beneficio, los deberes de los administradores y el principio de transparencia.

En primer lugar, con la finalidad de delimitar el propósito de beneficio, se establecen requisitos en el artículo tercero. Los mismos deberán ser cumplidos por "todas las sociedades que decidan constituirse como tales, así como aquellas ya existentes que opten por acogerse al régimen de la presente ley" (Sistema B Argentina, 2016, p. 4). Es en este artículo donde se hace un reenvío directo a la Ley General de Sociedades, por lo que se establece que:

"Las Sociedades BIC deberán incluir en su contrato social, además de los requisitos exigidos por la Ley General de Sociedades, los siguientes:

- Especificar en forma precisa y determinada cuál es el impacto social y ambiental positivo y verificable que se obligan a generar;

- Indicar las causales de exclusión de los socios que ejecuten actos contrarios al espíritu de esta ley; y,

Exigir el voto favorable del $75 \%$ de los socios con derecho a voto para toda modificación del objeto y fines sociales, sin aplicarse en el caso de las sociedades anónimas, la pluralidad de voto" (Sistema B Argentina, 2016, p. 4).

En tal sentido, los requisitos líneas arriba detallados norman qué elementos deben señalarse expresamente en el estatuto para que la sociedades califiquen como de beneficio e interés colectivo. Como se ha mencionado anteriormente, los mismos aplican para 
aquellas sociedades que se constituyan bajo otro tipo societario y que decidan, en los márgenes de su propio tipo societario, someterse también a esta ley.

En segundo lugar, en cuanto a la administración, el artículo cuarto del anteproyecto está redactado de una manera muy similar a los artículos presentes en la legislación estándar utilizada en varios estados de los Estados Unidos de América. Ello, en tanto, la decisiones de los administradores y gerentes deben tomar necesariamente en cuenta sus efectos en "(i) los socios), (ii) los empleados actuales y en general la fuerza de trabajo de la compañía, (iii) la comunidad, el medioambiente local y global, (iv) las expectativas a largo plazo de los socios y la sociedad, de tal forma que se materialice el fin común de la sociedad" (Sistema B Argentina, 2016, p. 4). Si bien la redacción es muy parecida a la contenida en las leyes de Estados Unidos, como en otros proyectos de ley en América Latina, se ha añadido además que "el cumplimiento de la obligación antedicha por parte de los gerentes solo podrá ser exigible por los socios y la sociedad" (Sistema B Argentina, 2016, p. 4). Es así que, se impide que un tercero interesado ajeno a la sociedad pueda demandar judicialmente el cumplimiento de las obligaciones de los gerentes y administradores, así como de los deberes fiduciarios de los directores.

En tercer lugar, el principio de transparencia es reconocido en el artículo sexto del anteproyecto de ley, por el cual se encomienda a los administradores la elaboración de un reporte anual en el cuál se demuestren fehacientemente todos los actos llevados a cabo con la finalidad de cumplir a cabalidad el propósito social previsto en el estatuto de la sociedad. Asimismo, este artículo establece expresamente que, "los socios designarán a un tercero independiente matriculado, que auditará el reporte anual que confeccionen los administradores" (Sistema B Argentina, 2016, p. 4). Finalmente, este reporté deberá ser además publicado por el Registro Público de Comercio de Argentina.

Sobre el anteproyecto de ley, Laura Ocampo, presidente del directorio de Sistema B Argentina, señaló: "Sobre la base de estas tres características es que este nuevo marco legislativo es necesario. Las sociedades BIC no pueden constituirse sobre la base de las figuras jurídicas existentes en la legislación de fondo basadas solo en el fin de lucro. La idea es incorporar a las Sociedades BIC a la ley de sociedades generales" (Comunica RSE, 2016). Ocampo hace referencia así, a la necesidad de la naturaleza de las sociedades de beneficio plasmada en la ley, sea para adoptar estas normas e incorporarlas en el tipo societario que se tiene o para constituirse desde el inicio con la categoría añadida de una 
sociedad BIC y regirse principalmente en lo señalado en el anteproyecto y derivar lo demás a la Ley General de Sociedades.

De manera adicional a los principios antes señalados y reconocidos en el anteproyecto, es importante señalar que el mismo, en su artículo quinto, presenta una innovación, el derecho de receso. "La adhesión de sociedades ya constituidas y registradas bajo el régimen previsto en la presente ley dará derecho de receso a los socios que hayan votado en contra de dicha decisión, en los términos del artículo 245 de la Ley General de Sociedades" (Sistema B Argentina, 2016, p. 4). Es así que, aquellos socios que se hayan opuesto a ser una sociedad de beneficio, podrán, de acuerdo a la legislación argentina, separarse de la sociedad con el reembolso del valor de sus acciones.

Si bien el anteproyecto de ley antes descrito se encuentra en evaluación en la Cámara de Diputados, los fundamentos que acompañaron su presentación indican la visión de aquellos que lo redactaron:

"El reconocimiento y la promoción de las sociedades BIC por parte del Estado será bien acogido y aprobado por emprendedores sociales, empresas familiares, sociedades, organizaciones en general, que desean formalizar sus valores y misión social; inversores de impacto social que desean invertir en empresas impulsadas por un propósito social u ambiental, y que exigen una protección más formal en contra del desvío de la misión; trabajadores que buscan empleos que se conecten con propósitos mayores; y la población en general que ha mostrado una tendencia a alinear sus consumos a sus valores, exigiendo a las empresas que sean socialmente responsables" (Sistema B Argentina, 2016, p. 3).

\subsubsection{Chile}

Actualmente, a través del Boletín $N^{\circ}$ 10321-03 de la Cámara de Diputados de Chile, se está promoviendo un proyecto de ley que regula a las sociedades de beneficio. Este proyecto fue presentado el 06 de octubre de 2015 y en la actualidad se encuentra en evaluación en la Comisión de Economía, Fomento, Micro, Pequeña y Mediana Empresa de la Cámara de Diputados de Chile.

El proyecto tiene como finalidad, "además de dar claridad a la identidad de las Empresas B, facilitar el cambio a Empresas B de empresas grandes, incluso aquellas 
transadas en bolsa" (Abramovay, 2013, p. 50). De manera paralela a la presentación del proyecto, el Ministerio de Economía, Fomento y Turismo de Chile colabora con otros organismos estatales, el empresariado, la sociedad civil y Sistema B Chile para promover el concepto híbrido de este tipo de personas jurídicas que además de su fin lucrativo, tienen un mandato social y medioambiental que atender.

El proyecto de ley contenido en el Boletín $\mathrm{N}^{\circ}$ 10321-03 de la Cámara de Diputados de Chile es conciso y cuenta de tres artículos, que tienen por objetivo el (i) reconocimiento; (ii) la delimitación de las funciones de los directivos, y (iii) la implementación de las sociedades de beneficio, denominadas empresas sociales en Chile.

En primer lugar, el proyecto de ley identifica claramente la identidad de las empresas sociales, indicando que son "personas jurídicas con fines de lucro en cuyos estatutos sociales pacten como parte de su objeto social, el de generar un impacto positivo en la sociedad y el medio ambiente y se encuentren registradas de conformidad a esta ley" (Boletín $\mathrm{N}^{\circ}$ 10321-03, 2015). En tal sentido, el proyecto tiene la finalidad de reconocer la naturaleza jurídica híbrida de las sociedades de beneficio y de la necesidad que el acuerdo de voluntades que se plasme en su estatuto social reconozca claramente la intención de, junto con el objeto social, tener un propósito de beneficio claro. Asimismo, al indicar que las mismas deben registrarse en conformidad con la ley que emanaría del proyecto, se entiende que las empresas sociales en Chile constituirían un nuevo tipo societario independiente aquellos tipificados en su Ley de Sociedades Anónimas y en su legislación comercial.

En segundo lugar, al exponer la naturaleza jurídica de las sociedades de beneficio, el proyecto de ley delimita las funciones de los directivos de acuerdo a la misma. "Los administradores, directores y accionistas de las empresas sociales - en el marco de sus funciones, derechos y obligaciones - deberán velar por el cumplimiento de los objetivos sociales y actuar siempre con prevalencia de éstos por sobre la maximización de las utilidades $\mathrm{u}$ otros intereses " (Boletín $\mathrm{N}^{\circ}$ 10321-03, 2015). El segundo artículo hace énfasis en el deber fiduciario de aquellos órganos decisores en la empresa de beneficio, en tanto los mismos deberán tener en cuenta la sinergia deseada entre el objeto social y el propósito de beneficio, por la cual los administradores, directores y accionistas deben incluir dentro del concepto del interés social no únicamente a la maximización de utilidades sino con igual importancia a la consecución del propósito de beneficio social 
o medioambiental, así como el cumplimiento de los principios de este tipo societario, como lo son la transparencia y el bienestar general. Esta redacción es bastante similar a aquella presente en distintos estados de los Estados Unidos de América cuando tratan sobre el rol fundamental y diferenciado que deben cumplir los administradores, directores y accionistas de las sociedades de beneficio.

Adicionalmente, el segundo artículo del proyecto de ley indica que "el incumplimiento de este deber dará acción a los accionistas y administradores para demandar la exigibilidad de los objetivos sociales más la indemnización de los perjuicios materiales y morales correspondientes" (Boletín $N^{\circ}$ 10321-03, 2015). La redacción de esta segunda parte del artículo es bastante precisa: se otorga el derecho de acción únicamente a accionistas y administradores para demandar la exigibilidad del objeto social y el propósito de beneficio, considerados ambos como los objetivos sociales. La posibilidad de acción diseñada para estos casos es revolucionaria en tanto generaría una jurisprudencia que debería ceñirse de la finalidad híbrida de las sociedades de beneficio y las consecuencias sociales, ambientales y personales que pudiera causar el actuar diferente de una sociedad constituida como tal.

Finalmente, el tercer artículo del proyecto de ley indica que "mediante uno o más decretos expedidos por medio del Ministerio de Economía, Fomento y Turismo, se reglamentarán los requisitos que deberán cumplir las Empresas Sociales para ser reconocidas como tales y las causales de eliminación del mismo, así como los requisitos para ser incorporadas y eliminadas del Registro" (Boletín $N^{\circ}$ 10321-03, 2015). Este artículo deriva al ámbito ministerial la reglamentación del proyecto de ley, por lo que el mismo es muy breve y conciso. Asimismo, indica que este reglamento deberá incluir la determinación de los requisitos de cumplimiento de las sociedades de beneficio de acuerdo a su naturaleza jurídica. Sin perjuicio de lo anterior, el artículo al crear un registro de sociedades de beneficio, estaría hipotéticamente asignando un carácter constitutivo al mismo, en tanto serían categorizadas las sociedades de beneficio como tales siempre y cuando consten en tal registro, cumpliendo los requisitos que se exija para el mismo.

Si bien aún se encuentra siendo evaluado por la Cámara de Diputados de Chile y el mismo será reglamentado por decreto del Ministerio de Economía, Fomento y Turismo de dicho país, es posible identificar una diferencia notoria con el modelo legislativo que se ha aplicado en los Estados Unidos de América. La misma, radica en que, si bien las 
sociedades de beneficio en Chile deben tener un beneficio público general y un beneficio público específico, no se ha propuesto en el proyecto la necesidad que el estándar de operaciones sea evaluado por terceros. Esta característica, primordial en las sociedades de beneficio, debe ser incluida por el legislador chileno en aquellos decretos ministeriales que sean expedidos, en tanto la misma permite la adecuada regulación interna de este tipo societario. Es el estándar evaluado por terceros el que garantiza el efectivo cumplimiento de las características de las sociedades de beneficio, como lo son el beneficio público, la transparencia, la exigibilidad del cumplimiento del propósito de beneficio y los deberes fiduciarios, todos ellos explicados en el capítulo precedente.

La existencia del proyecto de ley en Chile es, sin duda, un gran paso para la consolidación del fenómeno empresarial de beneficio y el cambio de paradigma a la hora de hacer negocios. No obstante, es importante analizar brevemente el marco legal actual en Chile para aquellas personas jurídicas que deseen, en el marco de las normas societarias existentes, aplicar principios que emanan de las sociedades de beneficio.

Si bien las sociedades pueden aplicar estos principios en su actuar diario, "la legislación de sociedades anónimas puede tener un conflicto respecto de extender el deber fiduciario de los directores" (Abramovay, 2013, p. 50), en tanto los principios que rigen en las sociedades de beneficio enfatizan como deber obligatorio de los directores de este tipo de personas jurídicas el cumplir el propósito de beneficio. Ello se contrapone a principios que se ven reflejados en diversas legislaciones comerciales, como la chilena, por la cual es deber de los directores el maximizar las utilidades para sus accionistas.

Es así que, la Ley de Sociedades Anónimas, Ley $\mathrm{N}^{\circ} 18.046$ de Chile, en su artículo 42, numeral primero, que "los directores no podrán: 1) Proponer modificaciones de estatutos y acordar emisiones de valores mobiliarios o adoptar políticas o decisiones que no tengan por fin el interés social" (Ley $\left.\mathrm{N}^{\circ} 18.046,1981\right)$. En tal sentido, siendo un deber imperativo de los directores no poder adoptar políticas o decisiones que no sean aquellas relacionadas al interés social y al giro del negocio, los directores de aquellas personas jurídicas constituidas en virtud de esta ley y que quisieran implementar un propósito de beneficio social o medioambiental estarían en incumplimiento de la misma al tomar decisiones que no vayan acorde con el objeto social de la persona jurídica.

Adicionalmente a lo expresamente señalado por la ley societaria chilena, es importante tener en consideración tanto a la doctrina como a la jurisprudencia que se 
refiere a las sociedades anónimas, siendo estas otra posible contingencia para personas jurídicas que quieran adoptar principios de las sociedades de beneficio en tipos societarios distintos. Juan Esteban Puga Vial, doctor en Derecho y profesor de Derecho Comercial en la Universidad de Los Andes, en su libro "La Sociedad Anónima y otras sociedades por acciones en el Derecho Chileno y comparado" indica que, se entiende como interés social a la maximización de las utilidades de la persona jurídica, por lo que es un deber imperativo de los directores atender tal maximización con la venta de bienes o la provisión de servicios. Asimismo, la Sentencia Rol. 4261-2005 de la Corte Suprema de Chile identifica al interés social con el ánimo de lucro y la maximización de utilidades que proviene de la consecución del interés social. En tal sentido, la necesidad del reconocimiento expreso de las sociedades de beneficio, o empresas sociales, como se denominan en el proyecto de ley, es importante para asegurar la dinámica sinérgica entre el objeto social y el propósito de beneficio social o medioambiental, así como la protección jurídica de los directores.

A pesar de lo antes expuesto, las personas jurídicas en Chile que han pasado por la certificación de B Lab y se consideran como Empresas B, son más de ochenta, teniendo una comunidad de empresarios y emprendedores atentos a este tipo de negocio y a la expectativa de la creación de este tipo societario. Felipe Contreras Haye, director de Alianzas y Expansión de Sistema B en Chile, en una entrevista con el Diario Concepción el 7 de junio de 2016, indicó que "El proceso en toda América Latina ha sido expansivo y rápido, pero el caso de Chile ha sido abrumante. A nivel nacional hay más de 80 empresas, lo que corresponde a poco más de un tercio de toda Latinoamérica". (Parra Tapia, 2016, p. 14). Tales cifras posicionan a Chile como el país con más personas jurídicas certificadas como Empresas B, luego de Estados Unidos y Canadá.

Sin duda, el desarrollo legislativo en Chile será muy importante para los países de la región, en tanto el mismo implicará que una gran cantidad de personas jurídicas constituidas bajo otros tipos societarios se transformen a la figura societaria de las sociedades de beneficio.

\subsubsection{Colombia}

Sistema B Colombia promueve en la actualidad un documento titulado "Propuesta Capítulo de Sociedades BIC", el cual tiene el objetivo de delimitar la naturaleza jurídica 
y societaria de las sociedades de beneficio. El texto, el cual tiene la finalidad de ser un proyecto de ley en el corto plazo, incluye dos definiciones: la definición de la categoría jurídica y la definición propósito de beneficio.

Por un lado, se definen como Sociedades BIC, de Beneficio e Interés Colectivo, a "aquellas sociedades constituidas válidamente que, además de actuar en beneficio e interés de sus accionistas, actúan en beneficio e interés de la colectividad y del medio ambiente" (Sistema B Colombia, 2015, p. 1). En la definición también se señala que el objeto social incluirá conjuntamente con el objeto social o "acto de comercio", el propósito de beneficio, llamado actividades de beneficio e interés colectivo.

Por otro lado, el beneficio e interés colectivo se define como "cualquier impacto material positivo o la reducción de algún efecto negativo en la comunidad y el medio ambiente medido en relación con un estándar independiente, derivado de la ejecución del objeto social de la compañía" (Sistema B Colombia, 2015, p. 1). La delimitación conceptual utilizada por los redactores de la propuesta colombiana es interesante en tanto han incluido un aspecto positivo, es decir el impacto concreto que cambia una realidad dada, como un aspecto negativo, en tanto también es un beneficio social o medioambiental que se mitigue o reduzca una circunstancia concreta. Asimismo, es en la definición del beneficio e interés colectivo en donde la propuesta colombiana incluye la necesidad de relacionar el propósito de beneficio con la medición de los estándares puestos en práctica por una entidad independiente.

Esta propuesta es también interesante en tanto la personería jurídica de las sociedades de beneficio en Colombia estarían regidas por la inscripción en el Registro Mercantil. "La calidad de sociedad BIC se adquirirá con la inscripción en el Registro Mercantil de la Cámara de Comercio donde la sociedad tenga su domicilio principal" (Sistema B Colombia, 2015, p. 1). En tal sentido, la inscripción sería constitutiva para que la persona jurídica sea catalogada como una sociedad de beneficio e interés colectivo. Ello es comparable con el proyecto de ley presentado en Chile, el cual contempla el carácter constitutivo de la inscripción de las sociedades de beneficio con la finalidad que las mismas sean reconocidas como tales una vez el cumplimiento de sus requisitos sean verificados por los registradores encargados.

La propuesta colombiana clarifica también en su artículo sexto y séptimo los deberes especiales de los administradores de las Sociedades BIC, añadiendo que los 
mismos deberán trabajar además de por la consecución del objeto social y el interés de la sociedad, por el cumplimiento del propósito de beneficio establecido en el estatuto de la misma. Asimismo, indica que las acciones judiciales contra los administradores en cuanto al incumplimiento del propósito de beneficio, solo podrán ser promovidas por los accionistas de la sociedad. Ello, excluye la posibilidad que terceros ajenos a la sociedad puedan accionar contra los administradores, posición común a otros proyectos redactados en América Latina.

Finalmente, la propuesta colombiana señala también que las personas jurídicas inscritas como Sociedades BIC pueden perder tal categoría cuando en los estatutos sociales no conste el propósito de beneficio a realizar y se les retire la inscripción. Así, perderían también la misma cuando la entidad reguladora evaluara a la sociedad y determinara que la misma no cumple su propósito de beneficio. La propuesta titula al artículo noveno como "pérdida de calidad de la Sociedad BIC" (Sistema B Colombia, 2015, p. 4), lo que daría a entender que la pérdida de esta categoría societaria implicaría que la sociedad sería irregular hasta el momento en que la opte enteramente por un tipo societario presente en la ley.

Si bien la propuesta vigente en Colombia es integral y abarca los puntos más importantes de la legislación estándar en cuanto a sociedades de beneficio, es importante articular la propuesta con la legislación comercial vigente en tanto este tipo de sociedades híbridas deben consolidarse como una categoría jurídica societaria accesible.

Si bien la circulación de la propuesta promovida por Sistema B Colombia es un gran paso para la promoción de las sociedades de beneficio en Colombia, es importante acotar también la flexibilidad de la legislación actual vigente, la cual tiene una innegable naturaleza lucrativa, ya que no excluye la posibilidad de implementar acuerdos internos que permitan la aplicación de principios propios de las sociedades de beneficio. "La transformación o implementación de Empresas B en las sociedades previstas en el Código de Comercio colombiano (sociedades colectivas, sociedades en comandita y en comandita por acciones, de responsabilidad limitada y la sociedad anónima" y en la sociedad por acciones simplificada (SAS), regulada por la Ley 1258 de 2008 es posible, pero requiere adoptar nuevas disposiciones estatutarias" (Abramovay, 2013, p. 51). Ello permite a aquellas personas jurídicas delimitar con mayor precisión su propósito de 
beneficio y tomar aquellas decisiones que coadyuven a la consecución de tanto el objeto social como de los fines sociales o medioambientales propuestos por la persona jurídica.

Sin embargo, aquellos tipos societarios contemplados en el Código de Comercio colombiano tienen una estructura más rígida que aquella regulada por la Ley 1258 de 2008, para las sociedades por acciones simplificadas (SAS). Por ello, "es conveniente aprovechar la versatilidad que ofrecen las sociedades por acciones simplificadas" (Abramovay, 2013, p. 51). Ello permite identificar a este tipo societario existente como amigable a los fines y propuestas de las sociedades de beneficio ya que a través de reformas estatutarias, pueden "modificarse esencialmente cláusulas del objeto social, el régimen de responsabilidad de los administradores y el informe de gestión" (Abramovay, 2013, p. 51). En tal sentido, ante la ausencia actual de la categoría jurídica, la legislación colombiana se muestra amigable en tanto ninguna disposición legal podría poner en riesgo la coexistencia de la realización de tanto el propósito de beneficio como el objeto social. 


\begin{tabular}{|c|c|c|c|c|}
\hline \multicolumn{5}{|c|}{ Tabla 5. Desarrollo legislativo comparado } \\
\hline & Estados Unidos & Argentina & Chile & Colombia \\
\hline Deno & $\begin{array}{l}\text { Benefit } \\
\text { Corporations }\end{array}$ & $\begin{array}{l}\text { Sociedad } \\
\text { Beneficio } \\
\text { Interés Colectivo }\end{array}$ & Em & $\begin{array}{l}\text { Sociedad } \\
\text { Beneficio } \\
\text { Interés Colectivo }\end{array}$ \\
\hline Reguli & $\begin{array}{l}\text { Ley en } 30 \text { estados } \\
\text { y Washington } \\
\text { D.C. }\end{array}$ & $\begin{array}{l}\text { Proyecto de ley en } \\
\text { discusión, Cámara } \\
\text { de Diputados. }\end{array}$ & $\begin{array}{l}\text { Boletín } \mathrm{N}^{\circ} 10321- \\
03 \text {, Cámara de } \\
\text { Diputados. }\end{array}$ & $\begin{array}{lr}\text { Propuesta } & \text { de } \\
\text { Capítulo } & \text { de } \\
\text { Sociedades } & \text { BIC, } \\
\text { Congreso de la } \\
\text { República. }\end{array}$ \\
\hline $\begin{array}{l}\text { Inserción en el } \\
\text { ordenamiento } \\
\text { jurídico } \\
\end{array}$ & Tipo societario & $\begin{array}{l}\text { Categoría } \\
\text { adicional } \\
\text { independiente }\end{array}$ & $\begin{array}{l}\text { Tipo societario } \\
\text { (Aparentemente) }\end{array}$ & $\begin{array}{l}\text { Categoría } \\
\text { adicional } \\
\text { independiente }\end{array}$ \\
\hline $\begin{array}{ll}\text { Propósito } & \mathrm{de} \\
\text { beneficio } & \end{array}$ & $\begin{array}{l}\text { Se reconoce y } \\
\text { debe especificarse } \\
\text { de manera precisa } \\
\text { y determinada. }\end{array}$ & $\begin{array}{l}\text { Se reconoce y } \\
\text { debe especificarse } \\
\text { de manera precisa } \\
\text { y determinada. }\end{array}$ & $\begin{array}{l}\text { Se reconoce e } \\
\text { incluye como } \\
\text { parte del objeto } \\
\text { social. }\end{array}$ & $\begin{array}{l}\text { Se reconoce e } \\
\text { incluye como } \\
\text { parte del objeto } \\
\text { social. }\end{array}$ \\
\hline $\begin{array}{lr}\text { Ampliación } & \text { de } \\
\text { deberes } & \text { y } \\
\text { protecciones } & \end{array}$ & 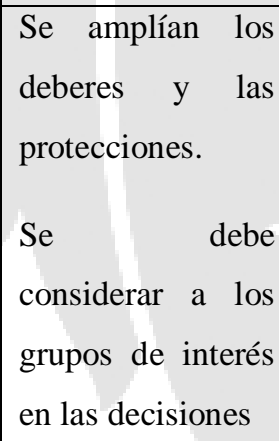 & 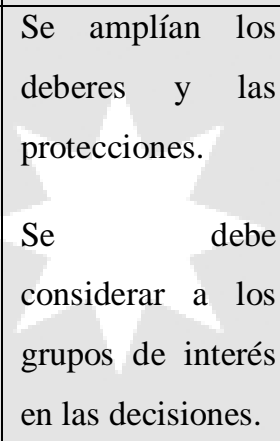 & $\begin{array}{l}\text { Se amplían los } \\
\text { deberes y las } \\
\text { protecciones. } \\
\text { No se mencionan } \\
\text { a los grupos de } \\
\text { interés. }\end{array}$ & $\begin{array}{l}\text { Se amplían los } \\
\text { deberes y las } \\
\text { protecciones. } \\
\text { No se mencionan } \\
\text { a los grupos de } \\
\text { interés. }\end{array}$ \\
\hline $\begin{array}{l}\text { Transparencia de } \\
\text { información }\end{array}$ & $\begin{array}{l}\text { Informe anual. } \\
\text { Debe ser auditado } \\
\text { por un tercero que } \\
\text { reporte y evalúe } \\
\text { las mejores } \\
\text { prácticas de la } \\
\text { organización. }\end{array}$ & $\begin{array}{l}\text { Informe anual. } \\
\text { Debe ser auditado } \\
\text { por un tercero } \\
\text { matriculado. } \\
\text { El Registro } \\
\text { Público } \\
\text { publicita } \\
\text { Internet. }\end{array}$ & $\begin{array}{l}\text { No hay mención a } \\
\text { la transparencia de } \\
\text { información. }\end{array}$ & $\begin{array}{l}\text { Informe de } \\
\text { gestión. } \\
\text { Se establecen } \\
\text { requisitos para } \\
\text { establecer quién } \\
\text { puede auditarlo. }\end{array}$ \\
\hline
\end{tabular}




\section{CAPÍTULO IV: INSERCIÓN A LA LEGISLACIÓN NACIONAL}

\subsection{Situación actual}

El ordenamiento jurídico nacional no regula la existencia de las sociedades de beneficio e interés colectivo. Asimismo, su posible regulación no ha sido discutida en sede legislativa por lo que hasta la fecha no existe proyecto de ley o iniciativa alguna que promueva el reconocimiento por parte del Estado y sus leyes societarias de este esquema de hacer negocios. Ello, a pesar de la clara tendencia presente en el mundo de los negocios, la cual reconoce la importancia de los principios del Desarrollo Sostenible y su inserción en las organizaciones empresariales.

Por un lado, existen personas jurídicas que se encuentran en permanente disyuntiva al no tener claro un lineamiento que les permita llevar a cabo el desarrollo de un propósito de beneficio social o medioambiental determinado. Esta situación, lleva a optar muchas veces de manera errónea por constituir una persona jurídica sin fines de lucro. Por otro lado, al no existir regulación alguna, muchas personas jurídicas constituidas bajo cualquiera de los tipos societarios reconocidos en la ley, optan por insertar modificaciones en su organización interna y externa de acuerdo a los estándares exigidos por el proceso de certificación independiente 'B Impact Assessment' con la finalidad de acreditarse como una Empresa B Certificada.

Como se mencionó con anterioridad, las Empresas B Certificadas son aquellas personas jurídicas que realizan actividad económica y reparten dividendos a sus accionistas, los cuales, sin importar su nacionalidad o tipo societario, aprueban el proceso de certificación independiente, llamado 'B Impact Assessment' y evaluado por B Lab. Ante la ausencia del reconocimiento legal de las sociedades de beneficio e interés colectivo, es conveniente analizar la situación actual de las Empresas B Certificadas en América Latina y el Perú.

“América Latina representa el 13,3\% de las Empresas B Certificadas a nivel mundial. El país con un volumen de expansión mayor en nuestro continente después de los Estados Unidos y Canadá es Chile (34,45\%), Argentina (18,06\%) y Colombia $(13,44 \%)$ ) (Caravedo, 2016, p. 126). Es importante, entonces, notar que los países latinoamericanos con mayor expansión, son los mismos que han desarrollado proyectos 
de ley que tienen por objetivo la regulación de las sociedades de beneficio e interés colectivo en su ordenamiento jurídico.

\begin{tabular}{|l|l|l|}
\hline \multicolumn{3}{|c|}{ Tabla 6. Número de Empresas B en América Latina } \\
\hline & \multicolumn{1}{|c|}{$\begin{array}{c}\text { Número de Empresas B } \\
\text { Certificadas }\end{array}$} & \multicolumn{2}{c|}{ Porcentaje } \\
\hline Chile & 82 & 34,45 \\
\hline Brasil & 55 & 23,11 \\
\hline Argentina & 43 & 18,06 \\
\hline Colombia & 32 & 13,44 \\
\hline México & 9 & 3,78 \\
\hline Uruguay & 6 & 2,52 \\
\hline Perú & 4 & 1,68 \\
\hline Ecuador & 3 & 1,26 \\
\hline Paraguay & 3 & 1,26 \\
\hline Bolivia & 1 & 0,42 \\
\hline Total & 238 & 100,00 \\
\hline & & Fuente: Caravedo, 2016, p. 127 \\
\hline
\end{tabular}

El caso del Perú es también comentado por Baltazar Caravedo en su libro "La energía social en las Empresas B”, en donde señala que “el Perú es un país en el que aún contamos con muy pocas Empresas B Certificadas (4). No obstante, hay una inquietud social contenida en los nuevos emprendimientos que se manifiestan. Si se examina el número de empresas que han consultado y mayormente desarrollado la evaluación online (B Impact Assessment), se puede ver que ha crecido con rapidez" (Caravedo, 2016, p. 126).

\begin{tabular}{|c|c|c|c|}
\hline \multicolumn{4}{|c|}{ Tabla 7. Número de empresas que han consultado la evaluación B en el Perú } \\
\hline & Número de empresas & Incremento anual & Incremento total \\
\hline 2010 & 4 & - & -2 \\
\hline 2011 & 8 & 2 & 2 \\
\hline 2012 & 19 & 2,38 & 4,75 \\
\hline 2013 & 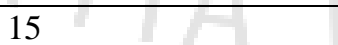 & 0,78 & 3,75 \\
\hline 2014 & 32 & 2,13 & 8 \\
\hline 2015 & 89 & 2,78 & 22,25 \\
\hline & & Fuent & Caravedo, 2016, p. 1 \\
\hline
\end{tabular}


Como manifiesta Caravedo, si bien el número de Empresas B Certificadas en el Perú es menor, el interés manifestado en las mismas y su correlato jurídico es creciente, muy especialmente por parte de emprendedores sociales y empresarios con propósito.

Por ello, como parte del análisis de la situación actual y ante la inexistencia de antecedentes jurídicos que regulen a las sociedades de beneficio e interés colectivo, es conveniente señalar que las Empresas B Certificadas, una vez que han aprobado el proceso de certificación mencionado en el segundo capítulo del presente trabajo, tienen que modificar sus Estatutos según las modificaciones legales propuestas por Sistema B Internacional en su página web para cada uno de los países de la región.

Las modificaciones sugeridas están dirigidas a dos partes del Estatuto Social: el objeto social y la administración de la sociedad. Las mismas responden a los elementos esenciales de las Empresas B, compartidos con las sociedades de beneficio e interés colectivo, los cuales son el propósito de beneficio, los deberes y protecciones ampliados a los directores y administradores, y la transparencia de información.

En cuanto al propósito de beneficio, se indica a las Empresas B Certificadas colocar luego de la descripción del objeto social el siguiente párrafo:

"En el cumplimiento del objeto social la sociedad procurará generar un beneficio o impacto material positivo en la comunidad, las personas vinculadas a la sociedad y en el medio ambiente. Sólo los socios/accionistas podrán exigir a sus órganos sociales como el Directorio y/o los gerentes el cumplimiento de la voluntad social de integrar en sus actividades los fines y objetivos sociales y ambientales que se describen en el objeto social" (Sistema B Internacional, 2016).

En cuanto a la ampliación de deberes y protecciones a los directores y administradores, Sistema B Internacional sugiere mencionar en la parte general del Estatuto que haga mención a la administración de la sociedad, los siguientes párrafos:

"En el ejercicio de sus funciones y facultades los directores, gerentes, administradores y apoderados deberán considerar no sólo los intereses de los socios/accionistas, sino también a sus trabajadores o colaboradores, clientes, proveedores, consumidores y demás partes directa o indirectamente vinculadas a la sociedad. Asimismo, deberán velar por el interés colectivo y de la comunidad donde la sociedad desarrolle sus actividades, incluyendo el cuidado del medio ambiente y el respeto a la cultura local.

Los administradores, por intermedio del Directorio y/o de la Gerencia General, deberán dejar constancia en la memoria anual o en sus informes y comunicaciones 
periódicas tanto al interior de la sociedad como frente a la opinión pública de las acciones tomadas para integrar sus actividades económicas con su propósito social y/o ambiental.

Las obligaciones que asumen los directores, gerentes, administradores y apoderados de la sociedad conforme a esta cláusula sólo son exigibles de manera exclusiva por los socios/accionistas de la sociedad, no creando derechos especiales en favor de terceros."

Los párrafos recomendados por Sistema B para las personas jurídicas que han obtenido la Certificación B varían de país en país según cada legislación. La intención de insertar los mismos en el estatuto social responde al interés de Sistema B en que las Empresas B se comprometan a través de una vinculación jurídica con su propósito de beneficio y la variación jurídica que el mismo trae como consecuencia en las personas jurídicas.

Sin embargo, en el Perú, hasta el momento, ninguna de las Empresas B Certificadas ha insertado los párrafos recomendados por Sistema B en su estatuto social. Por ello, aún no es posible saber si los mismos serán inscritos con facilidad en Registros Públicos y cuál será el criterio que los Registradores Públicos utilicen. Es de prever que dicho criterio no será uniforme y por tanto cada Empresa B tendrá una discusión con el Registrador Público que le sea asignado para lograr satisfactoriamente la inscripción de los párrafos recomendados y conservar la Certificación B a largo plazo.

Por un lado, la inserción del primer párrafo recomendado por Sistema B, en cuanto al objeto social, puede ver denegada su inscripción en tanto el artículo 11 de la Ley General de Sociedades indica que "la sociedad circunscribe sus actividades a aquellos negocios u operaciones lícitos cuya descripción detallada constituye su objeto social" y también que "la sociedad no puede tener por objeto desarrollar actividades que la ley atribuye con carácter exclusivo a otras entidades o personas". El Registrador podría aducir que no está comprendido en el objeto social la generación de un beneficio o impacto positivo en grupos de interés que exceden la estructura societaria. Más aún, podría indicar que tales actividades corresponden a personas jurídicas sin fines de lucro.

Por otro lado, añadir el segundo párrafo recomendado por Sistema B, de manera general, podría también traer complicaciones al incluir en un solo párrafo distintos términos y referencias a posiciones (directores, gerentes, administradores y apoderados) que no hay en todos los tipos societarios contemplados en la ley. De la misma manera, la inserción de este párrafo adicional solo es entendible en caso se inserte también el primer párrafo recomendado por Sistema B. 
La existencia de estas personas jurídicas, y de aquellas que operan bajo la lógica híbrida previamente analizada, aún aquellas que no pretenden lograr la Certificación B, se ve dificultada porque en el ordenamiento jurídico nacional no hay reconocimiento legal alguno para aquellas figuras societarias que contemplen además de la realización de actividades económicas, la inserción de propósitos altruistas que se inserten en la estructura organizacional de la persona jurídica.

\subsection{Respuesta del Derecho Empresarial}

El Derecho no puede ser ajeno a las importantes transformaciones que están sucediendo en el mundo empresarial. En específico, el Derecho Empresarial debe estar a la vanguardia de las necesidades sociales y económicas. Como es sabido, "las empresas ya no son únicamente entidades productoras de bienes o servicios que buscan el lucro a cualquier costo. Dentro de una concepción moderna, las empresas son ahora entidades responsables por su entorno, porque justamente de ese entorno dependen y se nutren" (Hundskopf, 2008, p. 150).

Las sociedades de beneficio e interés colectivo pueden considerarse como un modelo de sociedad de vanguardia que reconoce y asume integralmente la responsabilidad de su entorno, a través de la inclusión de un propósito de beneficio social o medioambiental en sus operaciones diarias. Su rápida expansión a través del mundo, y muy especialmente en América Latina, ha creado para ellas mercados específicos, en donde consumidores e inversionistas están interesados en participar de su desarrollo y expansión.

Este modelo de empresa debe ser necesariamente estudiado y evaluado desde la óptica del Derecho Empresarial, en tanto es esta disciplina dentro del Derecho la que está preparada para conocer y comprender el fenómeno, así como aplicarlo a la realidad nacional. La misión del Derecho Empresarial no es fácil, en tanto "el panorama es cada vez más complejo por el incremento de las inversiones, los adelantos de la ciencia y tecnología, y el propio desarrollo y modernidad del derecho y a ello busca dar una rápida respuesta el Derecho Empresarial, que comprende un conjunto de materias jurídicas tanto de derecho público como de derecho privado y de derecho social, que se aplican directamente a las empresas" (Hundskopf, 2008, p. 150).

Con los recursos antes descritos, esta disciplina tiene las herramientas necesarias para estudiar y comprender la naturaleza jurídica de las sociedades de beneficio e interés 
colectivo, así como reconocer su profunda conexión con el cambio de paradigma analizado en la presente investigación, el cual influye en el comportamiento de los actores empresariales y debe ser reconocido por el Estado, en tanto es un cambio positivo para la sociedad y el medioambiente.

El Derecho Empresarial, al ser "multidisciplinario, genérico y compilador" y la "rama del derecho que más se aproxima a la administración y la economía" (Hundskopf, 2008, p. 151) debe brindar respuesta al surgimiento de las sociedades de beneficio e interés colectivo, estudiando su naturaleza jurídica y la viabilidad de la inserción de sus elementos esenciales en las estructuras societarias existentes.

El presente trabajo de investigación es un primer esfuerzo por, desde el ámbito del Derecho Empresarial, dar a conocer la existencia de las sociedades de beneficio e interés colectivo, así como del gran potencial que las mismas tienen para generar cambios positivos que hagan posible realizar una actividad empresarial compatible con el bienestar social y medioambiental de la ciudadanía.

\subsection{Regulación en el ordenamiento jurídico peruano}

Las sociedades de beneficio e interés colectivo pueden insertarse al ordenamiento jurídico peruano en tanto las mismas no contravienen la legislación nacional. El artículo primero de la Ley General de Sociedades refleja el cambio de una sociedad con fines mercantiles a una sociedad comercial, en la cual busca la consecución de actividades económicas con la finalidad de obtener un beneficio económico.

Por ello, los elementos esenciales analizados en el Capítulo II de la presente investigación pueden adecuarse a nuestro ordenamiento jurídico. Es importante analizar las diversas opciones legislativas que se han tomado en cuenta en América Latina para regular a las sociedades de beneficio e interés colectivo. El fenómeno de investigación debe ser aplicado a nuestra realidad de la manera que resulte más coherente para nuestro ordenamiento jurídico y más práctica para el usuario que tendría este modelo de empresa como opción a la hora de realizar sus actividades empresariales.

\subsubsection{Opciones legislativas en Latinoamérica}

Las sociedades de beneficio e interés colectivo son objeto de constante debate jurídico en cuanto a su inserción a las legislaciones societarias. Como se ha mencionado en los capítulos anteriores, el origen de esta figura se dio en los Estados Unidos de América, y 
su aprobación legislativa e incorporación a las leyes comerciales han sido principalmente en treinta estados y Washington D.C.

Por ello, su incorporación a los ordenamientos jurídicos latinoamericanos acarrea un necesario debate jurídico, en especial por las diferencias entre el Derecho Anglosajón y el Derecho Continental Europeo. El legislador latinoamericano tiene varios caminos para regular esta figura y debe hacerlo con responsabilidad y visión de futuro; sin embargo, será valiosa aquella opción legislativa que plasme la practicidad y el dinamismo de las sociedades de beneficio e interés colectivo en los ordenamientos jurídicos latinoamericanos. Como se ha analizado en los capítulos precedentes, esta es una categoría que puede insertarse de manera adicional y cómoda bajo las reglas orgánicas de otro tipo societario, añadiendo a este sus elementos esenciales.

No obstante, es necesario tener en consideración las opciones legislativas más comunes en cuanto a la regulación de las sociedades de beneficio e interés colectivo alrededor del mundo y en especial en América Latina. Por un lado, las mismas pueden adoptarse en la legislación societaria como un tipo societario específico, es decir, como un modelo jurídico de sociedad, el cual goce de particularidades orgánicas únicas que lo diferencien de todos los demás tipos societarios. Por otro lado, las sociedades de beneficio e interés colectivo pueden ingresar a un ordenamiento jurídico como una categoría jurídica societaria, sin necesidad de configurarse como un nuevo tipo societario en tanto la inclusión de sus elementos esenciales no se oponen a las disposiciones propias de los tipos societarios ya existentes.

Como se puede apreciar en el capítulo anterior, el desarrollo legislativo de las sociedades de beneficio e interés colectivo en las Américas muestra una realidad diversa. Por un lado, Estados Unidos de América incluye a este modelo de sociedad como un tipo societario distinto en las diversas legislaciones comerciales donde las benefit corporations han sido adoptadas. Esta corriente es seguida por países como Chile, en donde si bien la discusión jurídica es incipiente, se puede interpretar a partir del proyecto de ley en discusión que se le otorgaría el ser un tipo societario y por lo tanto incluirse en la ley como tal.

Si bien el proyecto de ley promovido en Chile mediante el Boletín $\mathrm{N}^{\circ}$ 10321-03 de la Cámara de Diputados es el más corto de los estudiados en el presente trabajo, se entiende de la lectura del mismo que se crea un nuevo tipo societario, el cual se 
reglamentará una vez aprobada esta ley. Si bien esta interpretación es personal, parece ser que el modelo adoptado por Chile sigue la tradición de Estados Unidos de incluir a esta persona jurídica como otro tipo de sociedad.

Por otro lado, países como Argentina y Colombia han tomado una posición práctica por la cual las sociedades de beneficio e interés colectivo no constituyen un nuevo tipo societario, si no se conciben como una categoría adicional a los tipos societarios existentes en sus leyes.

En Argentina, el proyecto de ley señala en su artículo primero: "Serán Sociedades de Beneficio e Interés Colectivo (BIC) las sociedades constituidas conforme a alguno de los tipos previstos en la Ley General de Sociedades $N^{\circ} 19.550$ y sus modificatorias, cuyos socios además de obligarse a realizar aportes para aplicarlos a la producción o intercambio de bienes o servicios, participando de los beneficios y soportando las pérdidas, se obliguen a generar un impacto positivo social y ambiental en la comunidad" (Sistema B Argentina, 2016, p. 4). En tal sentido, las sociedades de beneficio e interés colectivo se constituyen de acuerdo a un tipo societario existente en su ley general de sociedades y a este se le agregan los elementos esenciales señalados en el proyecto de ley, denominándosele Sociedad de Beneficio e Interés Colectivo.

En Colombia, la "Propuesta de Capítulo de Sociedades BIC" señala que son sociedades de beneficio e interés colectivo "aquellas sociedades constituidas válidamente que, además de actuar en beneficio e interés de sus accionistas, actúan en beneficio e interés de la colectividad y del medio ambiente" (Sistema B Colombia, 2015, p. 1). Por tanto, estas sociedades se constituyen en un tipo societario existente en la ley comercial colombiana y al regularse también por lo señalado en la propuesta, adoptan los elementos esenciales y la denominación de "Sociedad de Beneficio e Interés Colectivo".

Es importante mencionar que en la inclusión de las sociedades de beneficio e interés colectivo a los ordenamientos jurídicos latinoamericanos no hay una opción correcta o incorrecta. La labor de los promotores de la inclusión de esta sociedad, ya sea como tipo societario o una categoría jurídica societaria adicional, es optar por la manera más eficiente y práctica para el ordenamiento jurídico comercial en cuestión, así como para las personas naturales y jurídicas que lo conforman. La importancia de regular a las sociedades de beneficio e interés colectivo está directamente relacionada con la inclusión de sus elementos esenciales en su estructura orgánica, considerándose en un segundo 
plano su exclusividad como tipo societario o su accesoriedad como categoría jurídica societaria.

En el Perú, a la luz de la vigencia de la Ley General de Sociedades y su funcionamiento integral en el ordenamiento jurídico nacional, es valioso preguntarse cuál sería la mejor opción legislativa para que la realidad peruana adopte en sus estructuras internas a la sociedad de beneficio e interés colectivo. Si bien esta pregunta puede generar un amplio debate académico, la presente investigación tiene por objetivo proponer la regulación de las sociedades de beneficio e interés colectivo de la manera más práctica y cohesionada con el ordenamiento jurídico nacional, así como con las estructuras internas del Derecho Empresarial peruano.

\subsection{2. ¿Nuevo tipo societario?}

Con la finalidad de dilucidar cuál sería la mejor opción legislativa a tomar en el Perú, es importante revisar la doctrina societaria nacional en cuanto a los tipos societarios. La Ley General de Sociedades se caracteriza por su claridad y practicidad, lo que permite un adecuado marco normativo para la constitución de personas jurídicas societarias, las que se erigen como centros generadores de actividad económica en beneficio propio y de terceros.

Como menciona Enrique Elías Laroza al comentar el artículo 2 de la Ley General de Sociedades, "para poder constituir una sociedad se debe elegir obligatoriamente, uno de los siete tipos regulados por la Ley: la anónima, en cualquiera de sus modalidades, la sociedad colectiva, una de las dos comanditarias, la comercial de responsabilidad limitada o cualquiera de las dos sociedades civiles. En caso contrario, no hay sociedad" (Elías, 2000, p. 10).

En tal sentido, como él mismo señala, el artículo 2 de la Ley General de Sociedades "contiene un mandato aún más categórico que la Ley anterior: toda sociedad debe adoptar alguna de las formas previstas en la Ley General de Sociedades" (Elías, 2000, p. 10). El mandato categórico antes señalado, se debe entender conjuntamente con lo mencionado en la segunda oración del artículo 2 , la cual señala "las sociedades sujetas a un régimen legal especial son reguladas supletoriamente por las disposiciones de la presente ley". Por ello que aquellas personas naturales o jurídicas que quieran conformar una sociedad, deben adscribirse a lo expresamente normado en la legislación societaria. 
En el mismo análisis a las formas o tipos societarios, Elías se pregunta con gran interés si el mandato categórico de la ley, líneas atrás señalado, atenta o no contra la autonomía de la voluntad. Acompaña esta pregunta con otra, de gran interés para la realización de esta investigación: "¿No es la actividad económica algo cambiante, dinámico, que requiere constantemente nuevas formas societarias?" (Elías, 2000, p. 10).

La relectura de esta pregunta esbozada por Elías a la luz de la aparición de las sociedades de beneficio e interés colectivo trae al debate la existencia de los elementos esenciales que configuran a este nuevo modelo de sociedad. El mismo, se inserta en una realidad propia del Siglo XXI, inmediata, dinámica y cambiante, en la cual el surgimiento de un propósito más allá en sí mismo que la propia actividad económica irrumpe en la configuración orgánica de las figuras societarias tradicionales.

A pesar de ello, es importante y valiosa la conclusión a la que llega Elías: "La actividad económica requiere, es cierto, de mucha libertad, pero no es en nada menos necesaria su seguridad. Los tipos societarios han sido perfeccionados durante siglos y son conocidos por los personajes e instituciones que intervienen en la actividad económica. El que cada grupo pueda formar una sociedad mezclando las formas, creando nuevas, regulando de manera distinta las instituciones conocidas, o todo ello a la vez, nos aproximaría al caos y a la inseguridad de lidiar diariamente con sociedades de formas desconocidas" (Elías, 2000, p. 10).

La seguridad, como principal argumento para no permitir la libre o fácil incorporación de tipos societarios, nos permite reflexionar sobre la necesidad que los mismos funcionen orgánicamente en el ordenamiento jurídico nacional de acuerdo a sus características propias. Por tanto, modelos de sociedad innovadores como la sociedad de beneficio e interés colectivo, la cuál de por sí puede regularse perfectamente bajo las premisas normativas de otros tipos societarios, con la adición de sus elementos esenciales, no supondrían un nuevo tipo societario a insertarse en la Ley General de Sociedades.

Isaac Halperin, autor citado por Elías en su propia obra, explicó en 1978 acerca de la importancia de la tipicidad, como elemento jurídico de gran importancia al preservar la seguridad en el desarrollo de la actividad económica.

"La tipicidad consiste en la previsión y disciplina legislativa particular, sin que tenga importancia el medio técnico por el cual se alcanza el resultado. (...) En materia de 
sociedades, los constituyentes no pueden apartarse de los tipos creados por el legislador. Se funda ello en que la atipicidad es contraria a la seguridad de los negocios, por las dificultades a que daría lugar su funcionamiento." (Halperin, 1978, p. 303).

Halperin realiza un interesante análisis de la tipicidad aplicado al mundo societario. Como menciona, el legislador es aquel que forja los tipos societarios con intención especial a que los mismos vayan a satisfacer las necesidades de sus usuarios, quienes se constituirán en uno de ellos para realizar la actividad económica pensada. Conviene subrayar que aun cuando la atipicidad es contraria a la seguridad de los negocios, el cambio de paradigma expuesto en el presente trabajo lleva consigo una necesidad legítima de diversos actores de poder llevar a cabo sus emprendimientos económicos, sociales y medioambientales a través de un esquema societario.

Así pues, conviene citar nuevamente a Halperin, quien reconoce acerca de las potenciales diferencias que el cambio social y económico pueden traer consigo al Derecho y en específico a las sociedades reguladas.

"No existe peligro de anquilosamiento del régimen, porque el legislador debe satisfacer las nuevas necesidades con la creación de nuevos tipos o el remozamiento del sistema, y porque respetadas las características sustanciales del esquema legal, según los diversos tipos, los otorgantes pueden adoptar soluciones adecuadas al tipo, en reemplazo de las normas meramente supletorias" (Halperin, 1978, p. 303).

Como lo indica Halperin, el régimen legal no debe quedarse congelado en el tiempo, en tanto es responsabilidad del legislador estar atento al cambio social. En específico, el cambio de paradigma en el mundo de los negocios y el reconocimiento de las sociedades híbridas o empresas con propósito, es una tarea necesaria y pendiente para el ordenamiento jurídico nacional. Ahora bien, como se ha mencionado líneas atrás, al ser las sociedades de beneficio e interés colectivo perfectamente operativas bajo los preceptos legales de los tipos societarios presentes en la ley, salvo por la adición de sus elementos esenciales, el legislador puede utilizar sus recursos legislativos para la creación de categorías jurídicas societarias específicas que permitan la existencia de una ley cohesionada conectada con un cuerpo normativo específico que permita la introducción de este modelo de negocios a la realidad nacional. 


\subsubsection{Categoría jurídica societaria}

Como se ha indicado previamente, las sociedades de beneficio e interés colectivo tienen tres elementos esenciales que deben ser regulados: el propósito de beneficio, la ampliación de deberes y protecciones de los directores y administradores y la transparencia de información. La inserción de estos tres elementos modifica de manera puntual algunos aspectos de los tipos societarios previstos en la ley. Más aún, este nuevo modelo se nutre de la regulación de estos tipos societarios para operar orgánicamente.

Por consiguiente, es importante tener en consideración, para efectos prácticos y de cohesión legislativa, que considerar a las sociedades de beneficio e interés colectivo como una categoría jurídica societaria es una opción legislativa viable. Las razones a continuación intentan explicar esta postura como la más adecuada para la realidad nacional, siguiendo a su vez los modelos propuestos en Argentina y Colombia.

En primer lugar, la misma permitiría la inclusión de las sociedades de beneficio e interés colectivo con sus elementos esenciales al ordenamiento jurídico nacional sin la necesidad de crear un nuevo tipo societario, los cuales se caracterizan por tener elementos típicos y estables en la ley por un largo período de tiempo. Como menciona Cabanellas, "la tipicidad societaria no es un fin en si mismo sino un instrumento jurídico para obtener ciertos resultados, especialmente en materia de tráfico comercial" (Cabanellas, 1993, p. 80). Por ello, la adición de los elementos propios de la sociedad de beneficio e interés colectivo, no supondrían una modificación perniciosa del tipo societario, sino respondería a la necesidad de regular a las empresas con propósito, para que las mismas puedan operar de acuerdo al objeto social establecido por sus accionistas, así como al propósito de beneficio social o medioambiental establecido por estos mismos.

En segundo lugar, que las sociedades de beneficio e interés colectivo tengan el tratamiento de una categoría jurídica societaria adicional a cualquiera de los tipos societarios presentes en la Ley General de Sociedades permitiría reflejar en el ordenamiento jurídico el cambio de paradigma analizado en la presente investigación. Es importante reconocer que la actividad empresarial y el desarrollo de actividades económicas se encuentra influenciado en el Siglo XXI de los preceptos del Desarrollo Sostenible, así como de buenas prácticas de gobierno corporativo. Es importante que nuestro ordenamiento jurídico de respuesta a las necesidades de las nuevas visiones 
empresariales, así como a las exigencias de las nuevas generaciones, las cuáles serán los líderes de las nuevas economías. La actividad empresarial puede generar éxitos compartidos a través de la consecución de un plan de negocios estratégico, así como un propósito de beneficio social o medioambiental establecido y medible. El legislador no puede ignorar esta nueva vocación empresarial y el Estado no debería impedir a que el sector privado se autorregule en directo beneficio de la resolución de problemas para la sociedad o el planeta Tierra.

En tercer lugar, la inclusión de una categoría jurídica societaria brindaría la posibilidad a las personas jurídicas existentes a operar de acuerdo a su verdadera naturaleza híbrida. Ello permitiría que la misma, en plena capacidad de operar de acuerdo a las metas trazadas para su objeto social como para su propósito de beneficio, no tenga que autorregularse de manera desorganizada para adoptar los principios de las benefit corporations que no pertenecen al ordenamiento jurídico nacional y que por ende, no son reconocidos por el Estado ni por sus organismos u órganos administrativos.

Finalmente, aun cuando no es posible descartar la futura regulación de las sociedades de beneficio e interés colectivo a un verdadero tipo societario en la legislación comercial, se requiere de tiempo y práctica comercial para entender mejor los alcances de su naturaleza. Como bien señala Halperin, será el legislador el que impida por sí mismo el anquilosamiento del régimen, el cual considera un peligro para el Derecho Comercial y la tipicidad societaria, aunque hoy por hoy este nuevo modelo de sociedad puede funcionar a la perfección sin la necesidad de separarse e independizarse por completo de los tipos societarios existentes en la Ley General de Sociedades.

En consecuencia, con la finalidad de brindar una respuesta integral a un fenómeno de consecuencias positivas para los actores involucrados, el sector público y privado, es necesario primero promover un proyecto de ley que brinde la posibilidad de regularse, adicionalmente por lo dispuesto en los tipos societarios de la Ley General de Sociedades, con lo señalado en un cuerpo normativo independiente y adicional.

\subsection{Proyecto de ley}

Durante la elaboración del presente trabajo de investigación y con la finalidad de responder a las preguntas planteadas y objetivos propuestos en la delimitación temática, 
se ha elaborado un proyecto de ley que recoge las experiencias comparadas más valiosas e introduce principios propios de la realidad peruana al fenómeno de las sociedades de beneficio e interés colectivo.

Es importante mencionar que, durante la investigación de la presente tesis y su correspondiente proyecto de ley, se han mantenido distintas reuniones con miembros de Sistema B Perú, organización líder en el país en la promoción y apoyo a las Empresas B. La misma, a través de Baltazar Caravedo, ha mostrado su interés permanente en el desarrollo de la investigación por las implicancias jurídicas que conllevan las sociedades de beneficio e interés colectivo. En estas reuniones se ha discutido activamente sobre la naturaleza jurídica de las sociedades de beneficio e interés colectivo, así como de los elementos esenciales inspirados en las Empresas B. Adicionalmente, se le ha permitido al investigador tener la oportunidad de aprender acerca de las características y pormenores del proceso de certificación impulsado por B Lab, el B Impact Assessment.

Asimismo, con motivo de la elaboración del proyecto de ley, el cual contiene la fórmula legal correspondiente, la exposición de motivos, el análisis costo beneficio y los efectos sobre la vigencia de la norma en la legislación nacional, el investigador ha contado muy especialmente con la colaboración del Congresista de la República, Alberto de Belaúnde y los asesores de su oficina parlamentaria, quienes se han mostrado en todo momento interesados en impulsar a través de su labor parlamentaria el proyecto de ley producto de la presente investigación, en tanto este regula el reconocimiento de las sociedades de beneficio e interés colectivo y permite a emprendedores sociales y empresarios con propósito encontrar respuesta a sus necesidades en la ley. Consideramos que esta colaboración ha sido muy valiosa al acercar la labor académica de investigación proveniente de la universidad, en este caso de la Facultad de Derecho de la Universidad de Lima, a la labor legislativa y de políticas públicas. Es a través de colaboraciones como esta que pueden lograrse distintos objetivos concretos sustentados en investigaciones académicas sólidas.

Finalmente, con la intención de tener la mayor retroalimentación posible en cuanto al proyecto de ley consignado a continuación, se han mantenido reuniones con emprendedores sociales y empresarios con propósito, a quienes esta categoría jurídica societaria les permitiría enmarcar sus operaciones para la generación de beneficios económicos y la consecución de un propósito de beneficio altruista. Inclusive, el investigador participó como expositor y panelista de una sesión de preguntas y respuestas en la Mesa Técnica de Innovación Social, oficializada mediante Resolución Ministerial 
$\mathrm{N}^{\mathrm{o}}$ 374-2016-PRODUCE, el miércoles 12 de octubre de 2016 y organizada por el Ministerio de la Producción.

En tal sentido, la elaboración del proyecto de ley presentado a continuación no está abstraído de la realidad legislativa, de los conceptos promovidos por organizaciones informadas en el tema de investigación y tampoco de las expectativas y necesidades de los emprendedores sociales y empresarios con propósito. Durante el año de investigación para la presentación de la presente tesis, la misma se ha enriquecido con la interacción constante con diversos actores que tienen por objetivo realizar actividad económica con un propósito social o medioambiental que les permita generar un cambio positivo en la realidad. Este proyecto tiene como principal finalidad la generación de una empresa consciente del medio social y ambiental que la rodea, así como facilitar el funcionamiento de los emprendimientos sociales, muy valiosos en nuestro medio.

\section{PROYECTO DE LEY}

\section{FÓRMULA LEGAL}

PROYECTO DE LEY QUE REGULA LA

CATEGORÍA JURÍDICA SOCIETARIA

SOCIEDADES DE BENEFICIO E INTERÉS COLECTIVO (SOCIEDAD B.I.C.)

Artículo 1.- Ámbito de aplicación independiente y adicional. Podrán ser "Sociedades de Beneficio e Interés Colectivo" o en siglas "Sociedades B.I.C", todas aquellas personas jurídicas societarias constituidas o por constituirse bajo alguno de los tipos societarios previstos en la Ley General de Sociedades, Ley No 26887 , que opten adicionalmente por regularse por el régimen de la presente ley.

Artículo 2.- Definición de la categoría jurídica societaria. Las Sociedades de Beneficio e Interés Colectivo son personas jurídicas societarias constituidas válidamente bajo alguno de los tipos societarios previstos en la Ley General de Sociedades, Ley $N^{\circ}$ 26887, cuyos socios además de obligarse a aportar bienes o servicios para el ejercicio en común de actividades económicas, se obligan por su propia voluntad a generar un impacto positivo a través de la consecución de un propósito de beneficio social o medioambiental. 
Para efectos de la presente ley, se entiende por "beneficio e interés colectivo", el impacto material positivo o la reducción de un impacto negativo en la comunidad y/o el medioambiente.

Artículo 3.- Denominación. A la denominación que corresponda, según el tipo societario correspondiente y de acuerdo a lo establecido en el artículo 9 de la Ley General de Sociedades, se le añadirá la expresión “de Beneficio e Interés Colectivo”, su abreviatura o la sigla B.I.C.

Artículo 4.- Formalidades constitutivas adicionales. Las sociedades existentes o por constituirse que opten adicionalmente adecuarse al régimen de la presente ley, deberán hacerlo constar así en su pacto social y estatuto, así como obtener la inscripción correspondiente de los mismos en el Registro de Personas Jurídicas del domicilio correspondiente.

Asimismo, se regirán de acuerdo a las siguientes disposiciones:

i) La modificación del estatuto de las sociedades existentes que deseen adecuarse adicionalmente al régimen de la presente ley necesitará, en ambas convocatorias los quórums y mayoría de votos calificadas exigidas en su Estatuto para ello o será de aplicación lo dispuesto por la Ley General de Sociedades, Ley No 26887.

ii) La modificación del estatuto de las Sociedades de Beneficio e Interés Colectivo que deseen modificar el propósito de beneficio o suprimir la categoría adicional de Sociedad B.I.C. se regirá por las disposiciones del inciso anterior.

iii) Los socios o accionistas que estén manifiestamente en desacuerdo con los cambios en la sociedad mencionados en los incisos precedentes, podrán ejercer el derecho de separación de acuerdo a las disposiciones de la Ley General de Sociedades, Ley No 26887.

Artículo 5.- Propósito de beneficio. El estatuto de las Sociedades de Beneficio e Interés Colectivo deberá incluir, como artículo siguiente al que regule su objeto social, una 
descripción detallada del propósito de beneficio, el que puede ser social y/o medioambiental.

Se entienden incluidos en el propósito de beneficio los actos relacionados con el mismo que coadyuven a la realización de sus fines, aunque no estén expresamente indicados en el pacto social o en el estatuto.

Artículo 6.- Deberes y protecciones ampliadas a los directores o administradores. Adicionalmente a los deberes previstos para los directores o administradores de la sociedad, según los tipos societarios de acuerdo a la Ley General de Sociedades, Ley No 26887, estos deberán velar por la real consecución del propósito de beneficio definido en su estatuto social.

Los directores o administradores deberán además ponderar el impacto que sus acciones u omisiones tengan en los socios, los trabajadores, la comunidad, el medioambiente local y global y las expectativas a largo plazo de los socios en cuanto a la realización del objeto social y el propósito de beneficio.

El cumplimiento de los deberes ampliados a los directores o administradores previstos en la presente ley solo podrán ser exigidos judicialmente por los socios o accionistas mas no por terceros ajenos a la sociedad.

Artículo 7.- Transparencia de información. El representante legal deberá introducir prácticas de transparencia organizacional en la sociedad. Asimismo, deberá encomendar a un tercero independiente la elaboración de un Informe de Gestión sobre el impacto de la gestión de la sociedad en relación con el propósito de beneficio social y/o medioambiental. El Informe de Gestión deberá ser presentado ante los socios y accionistas en la Junta Obligatoria Anual conjuntamente con la Memoria Anual y los Estados Financieros, así como publicado en la página web de la sociedad con la finalidad que el mismo pueda ser consultado por cualquier ciudadano interesado.

Artículo 8.- Pérdida de la categoría jurídica societaria. La modificación estatutaria correspondiente o el incumplimiento de las obligaciones asumidas por aplicación de la presente ley conllevan a la pérdida de la categoría jurídica societaria de Sociedad de 
Beneficio e Interés Colectivo y su retorno a las disposiciones que le resultan de aplicación en las disposiciones correspondientes de la Ley General de Sociedades.

\section{EXPOSICIÓN DE MOTIVOS}

\subsection{OBJETIVO DEL TEXTO NORMATIVO PROPUESTO}

La iniciativa legislativa que se propone tiene como principal objetivo establecer un marco jurídico o regulatorio para las Sociedades de Beneficio e Interés Colectivo (en adelante, Sociedades B.I.C.) que responden a un cambio de paradigma en el mundo de los negocios, producto de que el desarrollo de la actividad empresarial ha ido incorporando en sus operaciones principios sustentables en coherencia con el Desarrollo Sostenible, con la finalidad de atender diversas problemáticas sociales y medioambientales de su entorno.

Las Sociedades B.I.C. son hoy en día una realidad que en la práctica se constituyen como una categoría jurídica societaria independiente y por tanto, adicional a los tipos societarios ya previstos en la Ley General de Sociedades, Ley N ${ }^{\circ} 26887$ Las mismas tienen naturaleza mixta, ya que sin dejar de lado la distribución de utilidades a los socios o accionistas; reconocen de manera adicional, la existencia de un propósito de beneficio público, ya sea social o medioambiental, el cual tiene la misma importancia que el cumplimiento del objeto social.

Por ello, la inserción de las Sociedades B.I.C. como categoría societaria a la legislación nacional brindaría el reconocimiento estatal a una realidad creciente y dinámica. El Estado cumpliría de esta manera con su obligación de brindar una respuesta a los diversos actores económicos, emprendedores sociales y empresarios, que trascendiendo los actuales esquemas societarios buscan operar con un propósito sustentable y transparente, que vaya más allá de los resultados económicos y genere éxitos compartidos para la sociedad y el planeta Tierra.

\subsection{JUSTIFICACIÓN DEL TEXTO NORMATIVO}

\subsubsection{Las obligaciones del Estado frente a la libertad de empresa y a participar en} la actividad económica de la Nación en una economía social de mercado 
El reconocimiento de la libertad está clásicamente asociado con el derecho de su titular a acciones negativas de parte del Estado, derecho a que ninguna instancia pública impida, obstaculice o estorbe el ejercicio de estas libertades. De ahí que los principales casos en que los tribunales tienen que pronunciarse sobre la libertad de empresa corresponden a supuestos en que el titular alega que una acción (cobro de tasas excesivas, incumplimiento de requisitos de constitución o funcionamiento, regulación de servicios, etc.) o inacción estatal estorba el ejercicio de esta libertad.

Estos casos le han permitido al Tribunal Constitucional desarrollar una doctrina sobre las libertades económicas en el marco de una economía social de mercado como la que reconoce nuestra Constitución, de la cual sirve destacar dos aspectos.

El primero de ellos, que corresponde ejercer la actividad económica en concordancia con los fines sociales superiores, como la salud o la seguridad y que el Estado tiene la función de orientar, promover y estimular que así sea². El segundo, que la libertad de empresa comprende el poder jurídico de constituir las empresas ${ }^{3}$; el cual sólo puede ejercerse en la medida que el propio Estado provee de un conjunto de normas que regulan los diferentes tipos societarios o categorías jurídicas entre los que el ciudadano tiene la libertad de escoger.

Por tanto, si consideramos ambos aspectos de las libertades económicas y en estricto de la libertad de empresa tenemos que el ciudadano tiene derecho a que el Estado le provea de regulaciones específicas (leyes, reglamentos, etc.) a través de las cuales

\footnotetext{
${ }^{2}$ Fundamentos 25 y 29 de la STC 034-2004-AI:

"el propio ejercicio de las llamadas libertades económicas no se concibe como fin en si mismo y ajeno al ideal del orden económico y social justo; prueba de ello es que la propia Constitución ha determinado los límites a su ejercicio, conforme se advierte de su articulo 59 $9^{\circ}$, sancionando el abuso de estas libertades en perjuicio de la moral, la salud y las seguridades públicas; de igual modo, el artículo $60^{\circ}$, condiciona el ejercicio del derecho de propiedad a su armonización con el bien común."

“... se aprecia en el artículo $58^{\circ}$ de la Ley Fundamental, la cláusula que establece que "(...) el Estado orienta el desarrollo del país y actúa principalmente en las áreas de promoción de empleo, salud, educación, seguridad, servicios públicos e infraestructura". Esta disposición se convierte en una finalidad constitucional expresa que se fundamenta en los principios de una economía social de mercado."

Fundamento 8 de la STC 3116-2009-AA:

"En este contexto, la libertad de empresa se erige como un derecho fundamental que garantiza a todas las personas a participar en la vida económica de la Nación, y que el poder público no sólo debe respetar, sino que, además, debe orientar, estimular y promover, conforme lo señalan los artículos $58 .^{\circ}$ y $59 .^{\circ}$ de la Constitución."

${ }^{3}$ Fundamento 9 de la STC 3116-2009-AA:

“De este modo, cuando el artículo 59. ${ }^{\circ}$ de la Constitución reconoce el derecho a la libertad de empresa está garantizando a todas las personas una libertad de decisión no sólo para crear empresas (libertad de fundación de una empresa) y, por tanto, para actuar en el mercado (libertad de acceso al mercado), sino también para establecer los propios objetivos de la empresa (libertad de organización del empresario) y dirigir y planificar su actividad (libertad de dirección de la empresa) en atención a sus recursos y a las condiciones del propio mercado, asi como la libertad de cesación o de salida del mercado."
} 
puedan ejercer su derecho a participar en la vida económica de la Nación en concordancia con los fines sociales que tienen especial valor en una economía social de mercado ${ }^{4}$.

En tal sentido, si recordamos que las sociedades tradicionales previstas en la Ley General de Sociedades y las personas jurídicas sin fines de lucro no contienen en su estructura orgánica el desarrollo de una actividad económica que priorice decisiones sustentables para diversos grupos de interés, como la comunidad, los trabajadores y los clientes; se constata el derecho de los ciudadanos de que el Estado, en respeto del derecho a la libertad de empresa y en cumplimiento de su deber de promoción del ejercicio de este derecho en concordancia con los fines sociales, reconozca una estructura normativa que contemple estos elementos de carácter altruista y esenciales que definen a las sociedades de beneficio o empresas con propósito.

En efecto, las Sociedades B.I.C., de naturaleza híbrida, permiten la existencia de un propósito de beneficio social o medioambiental insertado en la estructura organizacional de la empresa. Con ello, se permite que esta cumpla con su objeto social, repartir utilidades a sus socios o accionistas, al mismo tiempo que persigue el propósito de beneficio elegido por estos últimos.

De esta manera, la regulación de las Sociedades B.I.C. en el ordenamiento jurídico nacional es necesaria en tanto permite satisfacer a plenitud la libertad de participar en la actividad económica de la Nación, por la cual los socios puedan optar por un tipo societario previsto en la Ley General de Sociedades y a su vez por la categoría jurídica societaria planteada. Ello hará posible que se regulen orgánicamente de acuerdo a su verdadera naturaleza mixta, superando así la dicotomía tradicional entre personas jurídicas con fines de lucro y personas jurídicas sin fines de lucro.

Por último, sirve resaltar que si bien es posible alegar que nada impide a las personas jurídicas societarias incorporar los elementos esenciales de una sociedad de beneficio en su estatuto, y por tanto adecuar su actividad económica a estos; tal posición no puede considerarse como una alternativa a la promulgación de una norma que recogiendo estos elementos esenciales los regule para las Sociedades de Beneficio, ya que aquello supondría una situación de auto regulación que no brinda a estas sociedades un marco jurídico de uniformidad y estabilidad que les permita contar con seguridad

\footnotetext{
${ }^{4}$ Esto es lo que en doctrina se conoce como el derecho a prestaciones normativas por parte del Estado, el desarrollo del mismo puede revisarse en: Alexy, Robert, 1997, Teoría de los Derechos Fundamentales, Madrid: Centro de Estudios Constitucionales, pp. 194 y ss, 468 y ss.
} 
jurídica y reconocimiento en el ejercicio de sus actividades y en sus relaciones con terceros.

En efecto, este marco jurídico no sólo le distingue y permite la identificación de las Sociedades de Beneficio, sino que -y aquí está la principal diferencia - además les proporciona protección y seguridad para que puedan adecuar su vida societaria en función de sus tres elementos esenciales, como son (i) la satisfacción del propósito del beneficio, (ii) para el cual se requiere un régimen particular de responsabilidad de sus administradores o directores y, (iii) el deber de transparencia que permita a la comunidad verificar el cumplimiento de aquél propósito.

\subsubsection{Las obligaciones del Estado frente al derecho al medio ambiente equilibrado}

Nuestra Constitución reconoce el derecho al medio ambiente equilibrado y al principio de desarrollo sostenible y de prevención, todos ellos con la finalidad de conservar los recursos naturales no sólo para los ciudadanos presentes sino también para las generaciones futuras.

Cuando el Tribunal Constitucional ha tenido la oportunidad de pronunciarse al respecto ha destacado la importancia de la responsabilidad social de las empresas concebida como un requisito para cumplir con estas metas, lo que además, señala, debe ir acompañado de políticas de promoción para que el uso de los recursos procuren el bienestar general ${ }^{5}$.

Asimismo, en el ámbito del Derecho Internacional, el presente proyecto de ley se encuentra en concordancia con diversos artículos de cuerpos normativos regionales y mundiales que promueven el cuidado de la sociedad y el medioambiente. Los mismos son: los artículos 2 y 22 del Pacto Internacional de Derechos Económicos, Sociales y Culturales; los artículos 16 y 26 de la Convención Americana sobre Derechos Humanos - Pacto San José de Costa Rica y los artículos XXII y XXIV de la Declaración Americana de los Derechos y Deberes del Hombre.

En consecuencia, siendo que las Sociedades B.I.C. tienen un propósito de beneficio que puede tener carácter ambiental, y por ello pueden comprometerse con la promoción de desarrollar actividades de prevención o conservación de los recursos

\footnotetext{
${ }^{5}$ Fundamento Jurídico 22 de la STC 0048-2004-AI:

“...el desarrollo sostenible o sustentable requiere de la responsabilidad social: ello implica la generación de actitudes y comportamientos de los agentes económicos y el establecimiento de políticas de promoción y el desarrollo de actividades que, en función del aprovechamiento o uso de los bienes ambientales, procuren el bien común y el bienestar general."
} 
naturales en los términos que ellos especifiquen; su reconocimiento resulta coherente con la obligación del Estado de promover una política ambiental sustentable.

\subsection{CONTENIDO DEL TEXTO NORMATIVO: LAS SOCIEDADES DE BENEFICIO COMO UNA CATEGORÍA SOCIETARIA ADICIONAL Y SUS ELEMENTOS ESENCIALES}

La iniciativa legislativa para regular las Sociedades B.I.C. propone que esta figura jurídica adopte la forma de una categoría societaria adicional por la que puede optar cualquier persona jurídica que ya se encuentra constituida. Para estos efectos, la iniciativa se concentra en delinear los tres elementos esenciales que definen esta categoría. Estos elementos distinguen las Sociedades B.I.C. de otras personas jurídicas societarias y, por ello, su regulación resulta fundamental para poder reconocer esta categoría y permitir el adecuado funcionamiento de la estructura antes descrita.

a) Propósito de beneficio: El propósito de beneficio es el elemento por excelencia de las Sociedades B.I.C. El mismo debe ser específico y puede ser social y/o medioambiental. El propósito de beneficio es adicional e independiente al objeto social y sirve como referente organizacional para los gestores involucrados en el funcionamiento de la sociedad, los que deben trabajar coordinadamente para la realización de la actividad económica y la consecución del propósito de beneficio.

La importancia de su regulación radica en que, al consignar el propósito de beneficio en los estatutos sociales, se permite ampliar la posibilidad de desarrollar acciones no relacionadas estrictamente con el retorno sobre la inversión de los socios o accionistas, a diferencia de las empresas tradicionales, y amplía la obligación de rendir cuentas respecto del propósito de beneficio público" (Abramovay, 2013, p. 23).

No se propone una lista taxativa de propósitos de beneficio, siempre que los mismos sean orientados a la generación de un beneficio público orientado a una causa social o medioambiental determinada.

b) Deberes y protecciones a los directores o los administradores: Según el tipo societario, los directores o administradores de la sociedad tienen deberes y 
protecciones adicionales con motivo de la introducción del propósito de beneficio en la estructura de la sociedad.

Por un lado, los directores o administradores de la sociedad tienen como un deber adicional, correspondiente a su cargo, el velar por la promoción ordinaria y ordenada del propósito de beneficio social o medioambiental. Asimismo, se incorpora el deber de los directores de considerar, conjuntamente con el mejor interés económico para la sociedad, la ponderación de los efectos que sus acciones u omisiones puedan tener en los grupos de interés tales como los trabajadores, los clientes, la comunidad, el medioambiente local y mundial y los intereses a corto y largo plazo de la sociedad.

Por otro lado, de manera paralela a la asignación de nuevos deberes a los directores o administradores de la sociedad, se propone una mayor protección para los mismos. Esta protección les impide a los socios o accionistas demandar judicialmente por responsabilidad a sus directores o administradores por tomar decisiones sustentables pero que nos les generen los máximos beneficios. Adicionalmente, los directores o administradores también están protegidos de demandes por parte de los beneficiarios del propósito.

c) Transparencia de información: Las Sociedades B.I.C. tienen un estándar de transparencia superior, en tanto se debe cumplir formal y sustantivamente con la presentación de reportes anuales que consignen información acerca de sus operaciones económicas, sociales y medioambientales. Este informe debe también detallar los avances realizados con respecto al propósito de beneficio.

El Informe Anual de Beneficio debe ser elaborado por un tercero imparcial que esté en condiciones técnicas de auditar las operaciones económicas, sociales y medioambientales de la persona jurídica. El estándar definido por el tercero independiente "constituye en el cómo mínimo o en la guía para saber que se está caminando por el camino correcto hacia la consecución del objeto de beneficio público general" (Roncancio, 2013, p. 138).

La transparencia de información también se traduce en transparencia organizacional, por lo que las Sociedades B.I.C. deberán priorizar mantener informados a los diversos grupos de interés involucrados en sus operaciones económicas, sociales y medioambientales sobre las decisiones que pudieran impactarlos directa o indirectamente. 
El principio de transparencia antes señalado hace "prever que esta herramienta de revelar información facilitará una mayor inversión en sociedades de beneficio e interés colectivo y mejorará la lealtad del consumidor, al permitirle diferenciar una empresa con un verdadero propósito de una empresa con una buena estrategia de márketing" (Halbert, 2015, p. 43).

\subsection{LA PROPUESTA NORMATIVA COINCIDE CON EXPERIENCIAS COMPARADAS}

La experiencia comparada relativa a las Sociedades B.I.C. es dinámica y creciente, en tanto esta estructura jurídica está en proceso de regulación en diversos países alrededor del mundo y cuenta con una importante presencia en América Latina.

La conceptualización y regulación inicial de las Sociedades B.I.C., Benefit Corporations en inglés, se ha dado, desde el año 2010, en Estados Unidos. Esta categoría jurídica se ha insertado en las legislaciones de treinta estados ${ }^{6}$ y el distrito de Washington D.C., y ha permitido el surgimiento de importantes oportunidades de negocio, así como el cumplimiento de propósitos de beneficio sociales y medioambientales a gran escala.

Las implicancias de las Benefit Corporations en Estados Unidos han sido muy positivas, tanto para emprendimientos empresariales de pequeña y mediana escala como para corporaciones que han optado por regularse bajo esta legislación. De acuerdo con los investigadores Terry Halbert y Elaine Ingulli en su libro "Law and Ethics in the Buisiness Environment" (2015), “aproximadamente 68 millones de consumidores estadounidenses muestran una preferencia en sus decisiones de compra basados en un sentido social y medioambiental".

La regulación de las Sociedades B.I.C. en Estados Unidos ha seguido una legislación modelo, promovida por la organización sin fines de lucro B Lab. La misma contiene los elementos esenciales comunes a este modelo de empresa: el propósito de beneficio social o medioambiental, los deberes y protecciones ampliados a los directores y administradores, así como la transparencia y reportes. Adicionalmente, diversos estados han introducido innovaciones que tienen como finalidad la protección del propósito de

\footnotetext{
${ }^{6}$ Las Benefit Corporations están reguladas en los estados de Arizona, Arkansas, California, Colorado, Connecticut, Delaware, Florida, Hawái, Idaho, Illinois, Indiana, Luisiana, Maryland, Massachusetts, Minnesota, Montana, Nebraska, Nevada, New Hampshire, Nueva Jersey, Nueva York, Oregón, Pennsylvania, Rhode Island, Carolina del Sur, Tennessee, Utah, Vermont y Virginia del Oeste.
} 
beneficio a largo plazo; sin embargo, estas no afectan el contenido original de la legislación estándar.

En el 2015, Italia se convirtió en el referente europeo de las Sociedades B.I.C., al regular en la "Legge 28 dicembre 2015, n. 208" a la Società Benefit, como una categoría jurídica que permite a las sociedades italianas existentes, o aquellas por constituirse, a tener un propósito de beneficio social o medioambiental, así como a tomar decisiones sustentables que responden a diversos grupos de interés. La incorporación de las Sociedades B.I.C. en Italia, aun cuando la legislación no difiere de aquella estándar en Estados Unidos, es un gran aporte para los países en los cuales predomina el sistema Derecho Continental Europeo.

Por su parte, el Reino Unido y Canadá tienen en sus ordenamientos jurídicos modelos de negocio similares al modelo de las Sociedades B.I.C. Por un lado, el Reino Unido cuenta con las sociedades de responsabilidad limitada, Community Interest Companies, que tienen además de la finalidad empresarial, la misión de beneficiar a la comunidad. Por otro lado, Canadá cuenta con las Community Contribution Company. Adicionalmente, el cuerpo normativo societario Canada Business Corporations Act, se encuentra en revisión por parte del gobierno para regular con exactitud el modelo de las Sociedades B.I.C.

Por su parte, América Latina no es ajena al surgimiento y discusión legislativa acerca de las Sociedades B.I.C. Hoy en día Argentina, Chile y Colombia tienen proyectos de ley en discusión. Estos proyectos tienen como objetivo reconocer y regular la existencia de esta categoría jurídica y de tal manera, brindar a los empresarios y emprendedores la posibilidad de realizar actividad económica con propósito altruista.

Argentina, en el mes de febrero de 2016, presentó en la Cámara de Diputados el Anteproyecto de Ley de Sociedades B.I.C. La propuesta argentina conceptualiza también a las Sociedades B.I.C. como una categoría jurídica adicional a los tipos previstos en la Ley de Sociedades y menciona que todas las sociedades que decidan constituirse como tales, así como las ya existentes pueden acogerse a esta categoría jurídica societaria.

Chile, en el mes de octubre de 2015, a través del Boletín $\mathrm{N}^{\circ}$ 10321-03 de la Cámara de Diputados, promovió un proyecto de Sociedades B.I.C., el cual se encuentra en evaluación en la Comisión de Economía, Fomento, Micro, Pequeña y Mediana Empresa. La propuesta chilena propone reconocer a este modelo de sociedades y aplicar al mismo tanto a sociedades nuevas como a las sociedades existentes que así lo deseen, incluso aquellas listadas en bolsa. 
Finalmente, en Colombia se promueve un documento parlamentario titulado "Propuesta de Capítulo de Sociedades B.I.C.", el cual tiene por objetivo definir la naturaleza jurídica y societaria de las Sociedades B.I.C. Este documento tiene como finalidad reconocer y regular a las personas jurídicas societarias existentes o por constituirse que opten por el modelo de Sociedades B.I.C., así como presenta innovaciones referidas al rol del Registro Mercantil.

\section{ANÁLISIS COSTO BENEFICIO}

\subsection{SOBRE LOS BENEFICIOS}

El presente proyecto de ley beneficia al empresariado en general y a los emprendedores sociales en particular. El empresariado podrá acceder a una categoría jurídica que incorpora importantes elementos de sustentabilidad social y medioambiental y redefine el sentido del éxito empresarial. Los emprendedores sociales podrán ver el esquema organizativo de sus emprendimientos reconocidos y consolidar su actividad económica, así como su propósito de beneficio bajo la estructura de una Sociedad B.I.C.

Asimismo, incorporar a las Sociedades B.I.C. en la legislación nacional representa la actualización de vanguardia del Derecho Empresarial, por el cual la empresa no se encuentra aislada de la sociedad y el medioambiente, sino por el contrario, es parte de un sistema sobre el cual tiene mucha influencia. Finalmente, este proyecto beneficia a la sociedad en general, en tanto las Sociedades B.I.C. tienen en su doble finalidad, el resolver un problema público concreto.

Por ello, esta categoría jurídica implica un doble beneficio para la sociedad y/o la comunidad, sobre todo la que se encuentra en su entorno, ya que no sólo controla o remedia externalidades negativas, porque en principio no las genera, sino que su actividad económica genera externalidades positivas, es decir que provoca el bienestar de otros agentes en la sociedad. Los efectos externos no están considerados dentro del precio del bien, es decir, los beneficiarios de las externalidades (en caso sean positivas) no pagan por ellas.

En el caso de las sociedades B.I.C., estas tienden a ejecutar un propósito de beneficio determinado. Al cumplir con el propósito se generan externalidades positivas que no afectan directamente al consumidor (podría ser o no un beneficiario), sino a un beneficiario determinado por la sociedad B.I.C. 
Adicionalmente, a la reducción de externalidades negativas y generación de positivas, se suma también como un beneficio producido por la regulación de las Sociedades B.I.C. el que ellas generan un entorno o circuito económico propio que renueva y/o dinamiza en todos los eslabones de la cadena activan, desde las entidades de financiamiento hasta los consumidores.

En efecto, dadas las externalidades positivas, las empresas que adquieran la categoría adicional de Sociedades de Beneficio serán más atractivas, tendrán acceso a capitales enfocados en sociedades B.I.C., puesto que existe una serie de fondos de capital privado como Circle Up, City Light Capital, Equilibrium Capital Group y Grassroot Capital entre otras, que se concentran al $100 \%$ en financiar empresas con un enfoque social.

Adicionalmente existen mercados de deuda ofrecidos por bancos especializados en financiamiento de sociedad B.I.C. como el New Resource Bank (San Francisco, California), One Pacific Bank (San Francisco, California) y Green Choice Bank (Chicago, Illinois). Las sociedades que decidan convirtieres en B.I.C. tendrán acceso a mercados de capital como los descritos anteriormente, esto les permitirá financiar diversificar el riesgo de capital, abriendo una serie de nuevas oportunidades de financiamiento.

\subsection{SOBRE LOS COSTOS}

Como consecuencia de la aprobación del texto normativo propuesto no se genera ningún costo más que la adecuación ordinaria de los Registros Públicos para categorizar como Sociedades B.I.C. a todas aquellas personas jurídicas de la Ley General de Sociedades que además opten en su constitución por lo dispuesto en el presente proyecto de ley.

Adicionalmente, la competitividad de las empresas no tiene por qué verse afectada por una modificación societaria como la propuesta, por el contrario, la ley podría ayudar a que las empresas que crean convenientes modificar su forma societaria puedan consolidar su ventaja comparativa con respecto al mercado.

\subsection{SOBRE LA PONDERACIÓN}

En consecuencia, teniendo en cuenta que los beneficios involucran no sólo a las propias personas jurídicas que quieran adecuarse a la categoría de Sociedades B.I.C. sino a la 
sociedad que recibirá los impactos positivos sobre los ámbitos sociales y ambientales e incluso a la economía nacional que, a través de estas categorías societarias, podrá captar financiamiento de capitales extranjeros, pero que también promoverá un consumo responsable en la ciudadanía.

A comparación de ello, siendo que la implementación de la regulación propuesta no se advierten costos directos o indirectos, se evidencia, que desde una perspectiva socio- económica existen razones suficientes para aconsejar la aprobación de la iniciativa legal propuesta.

IV. EFECTOS DE LA VIGENCIA DE LA NORMA SOBRE LA LEGISLACIÓN NACIONAL

La aprobación del texto normativo propuesto no implica la modificación de la Ley General de Sociedades en tanto las Sociedades B.I.C. son una categoría jurídica societaria independiente y adicional a los tipos societarios expuestos en dicha ley.

Los elementos esenciales que presenta el proyecto de ley se incorporan de manera adicional a los distintos tipos societarios en las secciones correspondientes y de acuerdo con los órganos sociales pertinentes.

Por tanto, no se requiere una regulación posterior que desarrolle aspectos del proyecto de ley propuesto. Ello, sin perjuicio, que órganos del Estado quieran en el futuro promover a las Sociedades B.I.C. y decidan solicitar de ellas el cumplimiento de requisitos adicionales para acceder a diversos programas. 


\section{CONCLUSIONES}

- Sí es posible incluir a la sociedad de beneficio e interés colectivo en la legislación nacional. Su naturaleza jurídica y sus elementos esenciales son acordes con la Constitución Política, a los pronunciamientos del Tribunal Constitucional y a la legislación societaria vigente.

Las implicancias de incluir a la sociedad de beneficio e interés colectivo en la legislación nacional recaen en la creación de una categoría jurídica societaria, adicional e independiente a los tipos societarios previstos en la Ley General de Sociedades, Ley $\mathrm{N}^{\mathrm{o}}$ 2688. Las sociedades existentes o por constituirse que así lo deseen, pueden optar voluntariamente por regularse, además de las disposiciones propias a su tipo societario, por la ley correspondiente a las sociedades de beneficio e interés colectivo.

- Las sociedades de beneficio e interés colectivo se originaron en Estados Unidos. Sus orígenes conceptuales y elementos esenciales se desprenden del proceso de certificación B Impact Assessment, el cual otorga la categoría de Empresas B Certificadas a aquellas personas jurídicas con fines de lucro que tienen excelentes prácticas de sustentabilidad social y medioambiental.

Su naturaleza jurídica y económica responde a un cambio de paradigma en el mundo de los negocios. Este cambio inserta en el núcleo de la organización empresarial la consideración de las diversas implicancias sociales o medioambientales de sus operaciones. Más aún, permite a las personas jurídicas societarias el elegir un propósito de beneficio social o medioambiental específico cuya importancia sea equiparable a la actividad económica de la empresa.

- Los elementos esenciales de las sociedades de beneficio e interés colectivo son tres: (i) el propósito de beneficio social o medioambiental; (ii) la ampliación de deberes y protecciones a los directores y administradores de la sociedad y (iii) la transparencia de información.

La existencia de los elementos esenciales antes mencionados distingue muy especialmente a este modelo de hacer negocios en tanto la sociedad, sin alejarse de sus objetivos de éxito y rentabilidad económica, presta atención al bienestar social y 
medioambiental a través de la consecución de un propósito de beneficio con el que todos los miembros de la organización empresarial se identifican a la hora de realizar sus labores.

- Las sociedades de beneficio e interés colectivo han tenido una rápida en su desarrollo legislativo en las Américas. El fenómeno de las Empresas B Certificadas y su impacto positivo en la sociedad y el medioambiente ha permitido generar una atención especial hacia la necesidad de reconocer y regular a su correlato jurídico con la finalidad que las personas jurídicas que así lo deseen puedan operar de manera óptima.

Estados Unidos es el país líder en incluir a este modelo de sociedad en su legislación, en tanto 30 estados y el distrito de Washington D.C. ya han aprobado e incluido en su legislación a las Benefit Corporations.

Argentina, Chile y Colombia son los países más representativos en América Latina. Si bien estos países aún no cuentan con una ley que regule a este modelo de sociedad en sus ordenamientos jurídicos, los tres tienen proyectos de ley que se encuentran actualmente en discusión con probabilidades importantes de ser aprobados en un futuro cercano.

- La sociedad de beneficio e interés colectivo no constituye un nuevo tipo societario. La misma puede ser regulada como una categoría jurídica societaria adicional e independiente a los tipos societarios previstos en la Ley General de Sociedades, Ley $\mathrm{N}^{\circ}$ 2688. Su regulación es una respuesta concreta del Derecho Empresarial a los cambios más recientes en el mundo de los negocios, en el cual la actividad empresarial del Siglo XXI es realizada por ciudadanos corporativos con propósito, los cuales están conscientes de la sociedad y del medioambiente que los rodea.

El modelo que regule la inserción de las sociedades de beneficio e interés colectivo en el Perú debería considerar la presencia de los tres elementos esenciales (i) el propósito de beneficio social o medioambiental; (ii) la ampliación de deberes y protecciones a los directores y administradores de la sociedad y (iii) la transparencia de información. Asimismo, se debe definir el ámbito de aplicación de la ley y la definición de la categoría jurídica societaria, así como las formalidades constitutivas adicionales necesarias para ser una sociedad de beneficio e interés colectivo. 


\section{RECOMENDACIONES}

Durante el desarrollo de la presente investigación, el investigador ha tenido la valiosa oportunidad de mantener diversas reuniones con diferentes grupos de personas cuyo aporte ha sido de gran valor para la comprensión del fenómeno y su evaluación de acuerdo a la realidad nacional.

En las diversas reuniones sostenidas con abogados, académicos, asesores congresales, emprendedores sociales, empresarios con propósito y profesionales de distintos rubros, han surgido generalmente tres temas de interés que no han formado parte de la investigación. Por ello, si bien estos temas no son parte del presente trabajo,con la finalidad de definir el fenómeno de investigación y de mantener su cohesión argumentativa y académica, dejo constancia de los mismos con la finalidad que una posterior investigación pueda darles la consideración que se merecen.

- Se recomienda estudiar, desde la óptica del Derecho Tributario, si es pertinente o no otorgar algún beneficio tributario a aquellas sociedades de beneficio e interés colectivo que cumplan con algunos requisitos específicos.

La experiencia comparada es unánime en no incluir ni solicitar al Estado en las iniciativas legislativas cualquier tipo de beneficio tributario. La principal razón se debe a que las sociedades de beneficio e interés colectivo, como respuesta jurídica societaria al cambio de paradigma analizado en el presente trabajo, quieren comportarse como el nuevo estándar de actores empresariales y tributar como la ley lo exige.

Sin embargo, los cuestionamientos surgen especialmente por el lado de un grupo de emprendedores sociales, los cuales mencionan con frecuencia la necesidad de impulsar y potenciar sus proyectos a través de beneficios por parte del Estado.

- Se recomienda analizar, desde la teoría general de las personas jurídicas, la posibilidad de transformar específicamente a personas jurídicas sin fines de lucro a una sociedad de beneficio e interés colectivo.

El concepto de las sociedades de beneficio e interés colectivo está diseñado inicial y específicamente para personas jurídicas societarias que reparten utilidades, con la 
finalidad que la actividad empresarial absorba valores de sustentabilidad social y medioambiental.

No obstante, ante la inexistencia de este modelo de sociedad en el pasado, muchas personas han optado por constituir personas jurídicas sin fines de lucro o cooperativas. Por ello, han expresado su repetido interés en poder acceder a través de una transformación a ser personas jurídicas societarias, con la categoría adicional de sociedad de beneficio e interés colectivo.

- Se recomienda considerar, en el elemento esencial de transparencia de información, los criterios básicos que deberán seguir los terceros independientes que deban elaborar los Informes de Gestión de las sociedades de beneficio e interés colectivo. Ello, con la finalidad de evitar dobles estándares que permitan que predomine la informalidad y no consecución de los objetivos de las sociedades de beneficio e interés colectivo.

Es especial interés del investigador que las sociedades de beneficio e interés colectivo sean un vehículo societario conectado a la realidad social y medioambiental, a través de la cual se pueda generar un cambio verdadero y tangible. Para ello, será necesaria la labor de supervisión de aquellos llamados por ley a corroborar el verdadero funcionamiento de estas sociedades, su objeto social y propósito de beneficio. 


\section{BIBLIOGRAFÍA}

Abramovay, R.; Correa, M.; Gatica, Sebastián. y Van Hoof, B. (2013). Nuevas Empresas, Nuevas Economías: Empresas B en Sur América. Bogotá: Multilateral Investment Fund, member of the IDB Group.

Assembly Bill No. 361, Benefit Corporations (09 de octubre de 2011). Recuperado del sitio de internet de Información Legislativa del Estado de California: http://leginfo.legislature.ca.gov/faces/billTextClient.xhtml?bill_id=201120120A B361

B Lab (06 de septiembre de 2016). About B Lab. Recuperado de: https://www.bcorporation.net/what-are-b-corps/about-b-lab

B Lab, Benefit Corporation. (06 de septiembre de 2016). The Model Legislation. Recuperado de: http://benefitcorp.net/attorneys/model-legislation

Bjorklund, Victoria B., Fishman, James J. y Kurtz, Daniel L. (2012). New York Nonprofit Law and Practice: With Tax Analysis (Segunda Edición). Nueva York: Lexis Nexis.

Boletín N 10321-03 de la Cámara de Diputados de Chile, Proyecto de ley que regula las empresas sociales. (07 de octubre de 2015). Recuperado del sitio de internet de la Cámara de Diputados de Chile: https://www.camara.cl/pdf.aspx?prmID=11420\%20\&prmTIPO=TEXTOSESIO $\underline{\mathrm{N}}$

Bromberg, D. (2016). Problem solving with the private sector.. Estados Unidos: The Public Solutions Handbook Series.

Cabanellas, G. (1993). Derecho Societario Buenos Aires: Heliasta.

Caravedo Molinari, B. (2015). Transformando el mundo: factor liderazgo, Empresas B y sociedad. Lima: Universidad del Pacífico.

Caravedo Molinari, B. (2016). La energía social en las Empresas B. Lima: Universidad del Pacífico.

Castro, Ana; Burkhart, Megan y Sanchez, Adrian. (2013). Maryland Benefit Corporation Act: The State of Social Enterprise in Maryland. Univeristy of Maryland, 
Recuperado del sitio de internet del Robert H. Smith School of Business: http://www.slideshare.net/changematters/maryland-benefit-corporationsanalysis-full-report

Comunica RSE, Comunicación de Responsabilidad y Sustentabilidad Empresarial. (17 de febrero de 2016). Presentan Anteproyecto de ley de Sociedades de Beneficio e Interés Colectivo. Recuperado de http://www.comunicarseweb.com.ar/noticia/presentan-anteproyecto-de-ley-desociedades-de-beneficio-e-interes-colectivo

Elías, E. (2000). Derecho Societario Peruano: La Ley General de Sociedades del Perú. Tomo I. Trujillo: Editora Normas Legales.

Googins, B., Mirvis, P. y Rochlin, S. (2007). Beyond Good Company: Next Generation Corporate Citizenship. Nueva York: Palgrave Macmillan.

Governor's Bill No. 23, Benefit Corporations and Encouraging Social Enterprise (24 de abril de 2014). Recuperado del sitio de internet de la Asamblea General de Connecticut: https://www.cga.ct.gov/2014/TOB/s/pdf/2014SB-00023-R00$\underline{\text { SB.pdf }}$

Halperin, I. (1978). Curso de Derecho Comercial. Tercera Edición. Buenos Aires: Depalma.

Honeyman, R. (2014). The B Corp Handbook: How to Use Business as a Force for Good. Oakland, California: Berrett-Koehler Publishers.

Hundskopf, O. (2008). Derecho Comercial: Temas Societarios. Tomo VIII. Lima: Universidad de Lima.

Leclair, Mark S. (2014). Philanthropy in Transition. Nueva York: Palgrave Macmillan.

Ley $\mathrm{N}^{\circ}$ 18.046, Ley de Sociedades Anónimas. (22 de octubre de 1981). Cámara de Diputados de Chile.

Organización de Naciones Unidas. (1987) Informe de la Comisión sobre el Medio Ambiente y Desarrollo. Asamblea General A/42/427.

Parra Tapia, N. (7 de junio de 2016). Empresas B: nueva tendencia mundial que redefine el éxito organizacional. Diario Concepción, p. 14.

Puga Vial. J.E. (2011). La sociedad anónima y otras sociedades por acciones en el Derecho Chileno y comparado. Santiago de Chile: Editorial Jurídica. 
Raskin, Jamie. (8 de junio de 2011). The Rise of the Benefit Corporations. The Nation, June 27, 2011 Issue. Recuperado del sitio web de la revista The Nation: http://www.thenation.com/article/rise-benefit-corporations/

Richardson, Benjamin J. y Sjåfjell Beate. (2015). Company Law and Sustainability: Legal Barries and Opportunities. Reino Unido: Cambridge University Press.

Roncancio Rachid, R. (2013). Benefit Corporations: desde la primacía del accionista hacia la del bien común (Tesis Doctoral). Universidad de Navarra, España.

Senate Bill 690, Benefit Corporations (13 de abril de 2010). Recuperado del sitio de internet de la Asamblea General de Maryland: http://mgaleg.maryland.gov/2010rs/bills/sb/sb0690t.pdf

Sistema B Argentina. (2016). Fundamentos y Anteproyecto de Ley de Sociedades de Beneficio e Interés Colectivo. Buenos Aires, Argentina. Recuperado de: http://www.comunicarseweb.com.ar/sites/default/files/anteproyecto.pdf

Sistema B Colombia (2015). Propuesta Capítulo Sociedades BIC. Bogotá, Colombia.

Sistema B. (06 de septiembre de 2016). Misión, visión y valores. Recuperado de: http://www.sistemab.org/espanol/el-movimiento-global/valores

Stockwell, Matthew. (15 de enero de 2016). How to form a Benefit Corporation in Maryland. Recuperado del sitio de internet de la Biblioteca Pública de Derecho del Estado de Maryland: http://www.peoples-law.org/info/maryland-smallbusiness/how-form-benefit-corporation-maryland

U, Elizabeth. (2013). Raising Dough: The Complete Guide to Financing a Socially Responsible Food Business. Vermont, Estados Unidos de América: Chelsea Green Publishing.

Zhang, M. (1 de octubre de 2014). Connecticut Gets Its First Benefit Corporations as New Law Takes Effect. Hartford Courant. Recuperado de http://www.courant.com/business/hc-social-enterprise-bill-1001-20141001story.html 